VILNIAUS GEDIMINO TECHNIKOS UNIVERSITETAS

Edvardas METLEVSKIS

\title{
PLAČIAJUOSČIŲ PLANARIŲJỤ LĖTINIMO SISTEMŲ MODELIAI IR JŲ TYRIMAS
}

\section{DAKTARO DISERTACIJA}

TECHNOLOGIJOS MOKSLAI,

ELEKTROS IR ELEKTRONIKOS INŽINERIJA (01T)

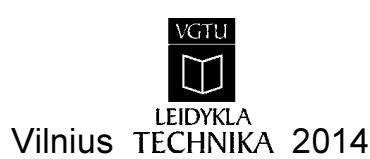


Disertacija rengta 2010-2014 metais Vilniaus Gedimino technikos universitete.

\section{Vadovas}

prof. habil. dr. Romanas MARTAVIČIUS (Vilniaus Gedimino technikos universitetas, elektros ir elektronikos inžinerija - 01T).

Vilniaus Gedimino technikos universiteto Elektros ir elektronikos inžinerijos mokslo krypties disertacijos gynimo taryba:

\section{Pirmininkas}

prof. habil. dr. Romualdas NAVICKAS (Vilniaus Gedimino technikos universitetas, elektros ir elektronikos inžinerija - 01T).

\section{Nariai:}

prof. dr. Algirdas BAŠKYS (Vilniaus Gedimino technikos universitetas, elektros ir elektronikos inžinerija - 01T),

doc. dr. Olga KURASOVA (Vilniaus universitetas, informatika - 09P), dr. Bartlomiej SALSKI (Varšuvos technologijos universitetas, elektros ir elektronikos inžinerija - 01T),

doc. dr. Artūras SERACKIS (Vilniaus Gedimino technikos universitetas, elektros ir elektronikos inžinerija - 01T).

Disertacija bus ginama viešame Elektros ir elektronikos inžinerijos mokslo krypties disertacijos gynimo tarybos posėdyje 2014 m. birželio 13 d. 9 val. Vilniaus Gedimino technikos universiteto senato posėdžiu salëje.

Adresas: Saulètekio al. 11, LT-10223 Vilnius, Lietuva.

Tel.: (8 5) 274 4956; faksas (8 5) 270 0112; el. paštas doktor@vgtu.lt

Pranešimai apie numatomą ginti disertaciją išsiusti 2014 m. gegužès 12 d.

Disertaciją galima peržiūrèti interneto svetainèje http://dspace.vgtu.lt/ ir Vilniaus Gedimino technikos universiteto bibliotekoje (Sauletekio al. 14, LT-10223 Vilnius, Lietuva).

VGTU leidyklos TECHNIKA 2253-M mokslo literatūros knyga

ISBN 978-609-457-683-6

(C) VGTU leidykla TECHNIKA, 2014

(C) Edvardas Metlevskis, 2014

edvardas.metlevskis@vgtu.lt 
VILNIUS GEDIMINAS TECHNICAL UNIVERSITY

Edvardas METLEVSKIS

MODELS OF BROADBAND PLANAR SLOW-WAVE SYSTEMS AND THEIR INVESTIGATION

DOCTORAL DISSERTATION

TECHNOLOGICAL SCIENCES,

ELECTRICAL AND ELECTRONIC ENGINEERING (01T)

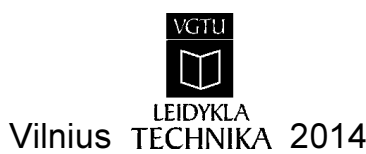


Doctoral dissertation was prepared at Vilnius Gediminas Technical University in 2010-2014.

\section{Supervisor}

Prof Dr Habil Romanas MARTAVIČIUS (Vilnius Gediminas Technical University, Technological Sciences, Electrical and Electronic Engineering 01T).

The Dissertation Defense Council of Scientific Field of Electrical and Electronic Engineering of Vilnius Gediminas Technical University:

\section{Chairman}

Prof Dr Habil Romualdas NAVICKAS (Vilnius Gediminas Technical University, Electrical and Electronic Engineering - 01T).

\section{Members:}

Prof Dr Algirdas BAŠKYS (Vilnius Gediminas Technical University, Electrical and Electronic Engineering - 01T),

Assoc Prof Dr Olga KURASOVA (Vilnius University, Informatics - 09P),

Dr Bartlomiej SALSKI (Warsaw University of Technology, Electrical and Electronic Engineering - 01T),

Assoc Prof Dr Artūras SERACKIS (Vilnius Gediminas Technical University, Electrical and Electronic Engineering - 01T).

The dissertation will be defended at the public meeting of the Dissertation Defense Council of Electrical and Electronic Engineering in the Senate Hall of Vilnius Gediminas Technical University at 9 a. m. on 13 June 2014.

Address: Saulètekio al. 11, LT-10223 Vilnius, Lithuania.

Tel.: +370 5274 4956; fax +370 5270 0112; e-mail: doktor@vgtu.lt

A notification on the intend defending of the dissertation was send on 12 May 2014.

A copy of the doctoral dissertation is available for review at the Internet website http://dspace.vgtu.lt/ and at the Library of Vilnius Gediminas Technical University (Saulètekio al. 14, LT-10223 Vilnius, Lithuania). 


\section{Reziumè}

Disertacijoje sprendžiama papildomų ekranų ịtakos meandrinių lètinimo sistemų dažninèms savybèms ịvertinimo problema. Pagrindiniai tyrimo objektai planariosios meandrinès lètinimo sistemos (PMLS) su papildomais ekranais, ju modeliai ir analizės bei sintezės metodai. Darbo tikslas - ištirti PMLS su papildomais ekranais, sukurti naujus modelius ir jų tyrimo metodikas leidžiančias įvertinti lètinimo sistemų kraštų bei galų efektus, sukurti tokių lètinimo sistemų parametrinès sintezès metodiką.

Darbe sprendžiami uždaviniai: elektrinio lauko meandrinèse lètinimo sistemose trimačio pasiskirstymo modeliavimo metodikos kūrimas; PMLS su papildomais ekranais modelių kūrimas, taikant specializuotus programų paketus; PMLS su papildomais ekranais kraštu bei galų efektų įtakos sistemos dispersinèms savybėms ir iejjimo varžos priklausomybei nuo dažnio tyrimas; PMLS su papildomais ekranais parametrinès sintezès metodikos kūrimas.

Disertaciją sudaro įvadas, keturi skyriai, bendrosios išvados, naudotos literatūros ir autoriaus publikacijų disertacijos tema sąrašai ir santrauka anglų kalba.

Ivadiniame skyriuje formuluojama tiriamoji problema, aptariamas darbo aktualumas, aprašomas tyrimų objektas, formuluojamas darbo tikslas ir uždaviniai, aprašoma tyrimų metodika, darbo mokslinis naujumas, rezultatų praktinė reikšmè, ginamieji teiginiai. İvado pabaigoje pristatomi pranešimai konferencijose disertacijos tema ir pateikiama disertacijos struktūra.

Pirmame skyriuje pateikiama literatūros analizè, apžvelgiamos plačiajuosčių planariujjų lètinimo sistemų konstrukcijos, jų taikymo sritys. Taip pat aptariami plačiajuosčių planariujų lètinimo sistemų tyrimams taikomi analitiniai ir skaitiniai metodai. Skyriaus pabaigoje formuluojami darbo tikslas ir uždaviniai.

Antrame skyriuje pasiūlomi nauji meandrinių lètinimo sistemų su papildomais ekranais kompiuteriniai modeliai, sukurti specializuotu programu paketu Sonnet ${ }^{\circledR}$ ir momentų metodu grissta elektrinio lauko meandrinèse lètinimo sistemose trimačio pasiskirstymo modeliavimo metodika.

Trečiame skyriuje pateikiami meandrinių lètinimo sistemų su papildomais ekranais kompiuterinių modelių dažninių savybių ir elektrinio lauko meandrinèse lètinimo sistemose trimačio pasiskirstymo tyrimo rezultatai.

Ketvirtame skyriuje pasiūloma meandrinių lètinimo sistemų su papildomais ekranais, ižemintais iš abiejų galų, parametrinès sintezès metodika ir ja remiantis sukuriamas parametrinès sintezès algoritmas.

Disertacijos tema paskelbti 5 moksliniai straipsniai, iš kurių trys - mokslo žurnaluose, ịtrauktuose i Thomson Reuters Web of Knowledge duomenų bazę. Disertacijos tema perskaityti aštuoni pranešimai mokslinėse konferencijose. 


\section{Abstract}

The dissertation investigates the issues of influence of additional shields on frequency characteristics of meander slow-wave system. The main objects of research include planar meander slow-wave systems with additional shields, their models and the methods of analysis and synthesis. The primary purpose of this dissertation is to investigate the planar meander slow-wave systems with additional shields by creating new models and their investigation techniques which allow to evaluate the effects on the edges and ends of slow-wave systems and create the technique for parametric synthesis of such slow-wave systems.

The paper approaches a few major tasks such as: creation of technique for modelling of 3D electric field distribution in meander slow-wave systems; creation of models of planar meander slow-wave system using high-frequency EM software; investigation of influence of effects on the edges and ends of meander slow-wave system with additional shields on their dispersive properties and input impedance; creation of technique for parametric synthesis of meander slowwave system with additional shields.

The dissertation consists of four parts including Introduction, 4 chapters, Conclusions, References and Summary in English.

The introduction reveals the investigated problem, importance of the thesis and the object of research and describes the purpose and tasks of the paper, research methodology, scientific novelty, the practical significance of results examined in the paper and defended statements. The introduction ends in presenting the author's presentations in conferences on the subject of the defended dissertation and defining the structure of the dissertation.

Chapter 1 revises used literature. At the end of the chapter, conclusions are drawn and the tasks for the dissertation are reconsidered.

Chapter 2 describes proposed new computer models of meander slow-wave system with additional shields, which are created using Sonnet ${ }^{\circledR}$ software. Moment method based technique for modelling of 3D electric field distribution in meander slow-wave system is also described.

Chapter 3 describes the results of investigation of frequency characteristics of meander slow-wave system with additional shields and modeling of $3 \mathrm{D}$ electric field distribution.

In Chapter 4 the technique for parametric synthesis of meander slow-wave system with additional shields grounded at both edges is proposed.

5 articles focusing on the subject of the discussed dissertation are published including three articles in the Thomson Reuters Web of Knowledge register. 9 presentations on the subject have been given in conferences at national and international level. 


\section{Žymèjimai}

\section{Simboliai}

$2 A$ - meandro laidininko ilgis;

A - koeficientas;

a - koeficientas, matmuo;

B - koeficientas;

b - koeficientas;

C - talpa;

$C_{1}$ - ilginè talpa;

$\mathrm{c}_{0} \quad-$ šviesos greitis vakuume;

E - kompleksinè elektrovara;

$f \quad$ - dažnis;

$G \quad-$ Gryno funkcija;

$g \quad$ funkcija;

h - matmuo;

I - srovès stipris;

$i \quad-$ momentinis srovès stipris, eilès numeris;

K - atspindžio koeficientas;

$k_{\mathrm{L}} \quad-$ lètinimo koeficientas; 


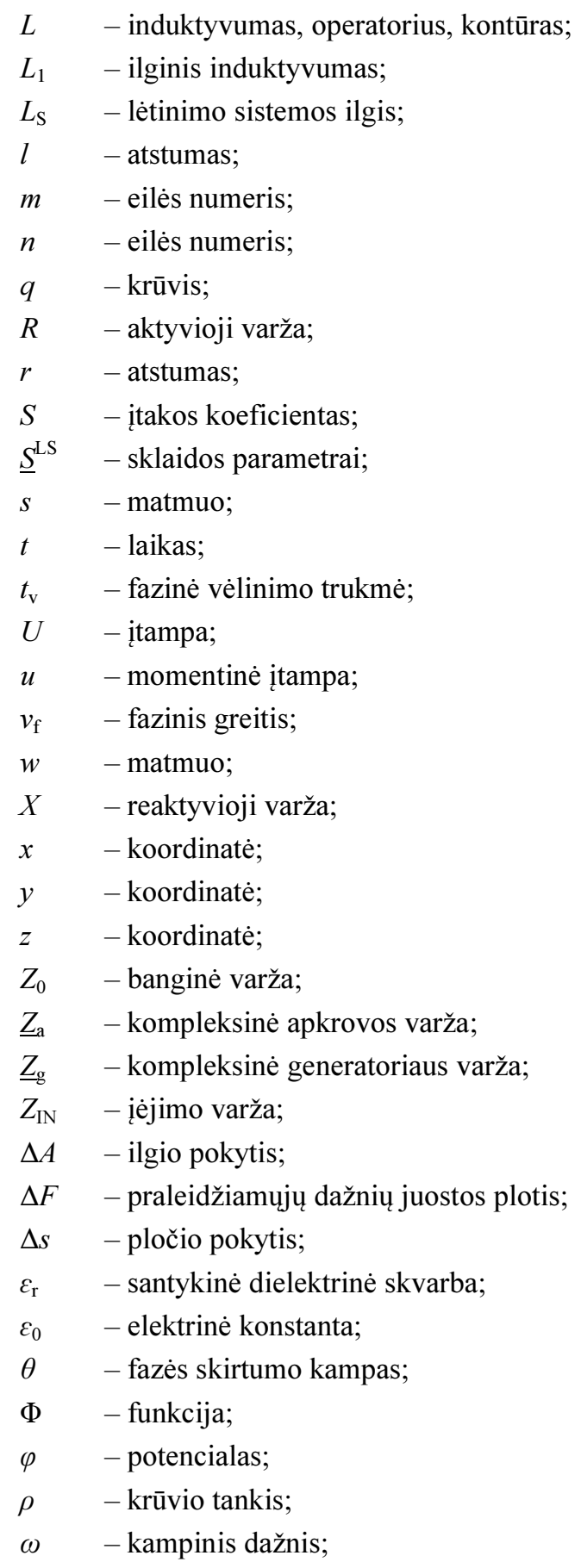



[A] - koeficientų matrica;
[q] - krūvių matrica;

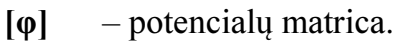

\section{Santrumpos}

BBEV - bėgančiosios bangos elektroninis vamzdis;

BELS - baigtinių elementų laiko srities metodas;

BEM - baigtinių elementų metodas;

BSLS - baigtinių skirtumų laiko srities metodas;

BSM - baigtinių skirtumų metodas;

DL - daugialaidè linija;

MoM - momentu metodas;

PMLS - planarioji meandrinè lètinimo sistema;

PPLS - plačiajuostè planarioji lètinimo sistema;

RFID - radijo dažnio identifikavimo technologija;

VL - vèlinimo linija;

EM - electromagnetic software. 



\section{Turinys}

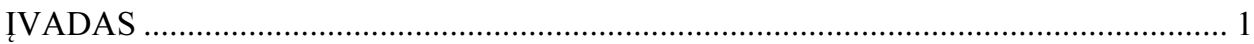

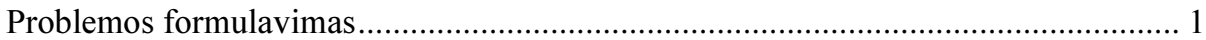

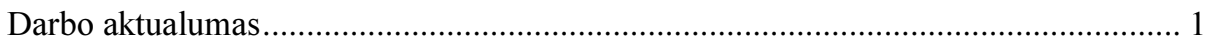

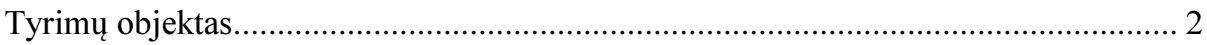

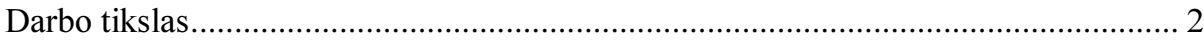

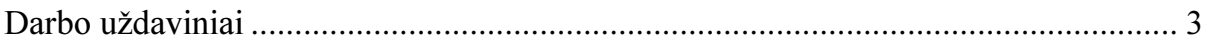

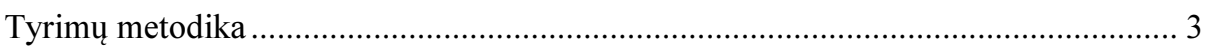

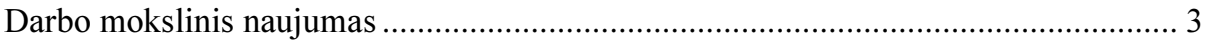

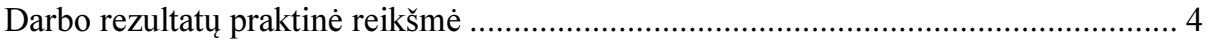

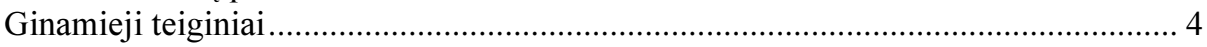

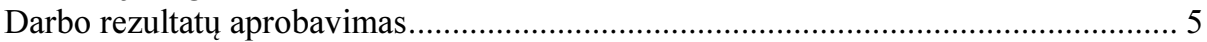

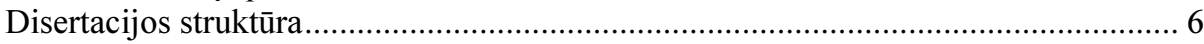

1. PLAČIAJUOSČIŲ PLANARIŲJŲ LĖTINIMO SISTEMŲ IR JŲ ANALIZĖS

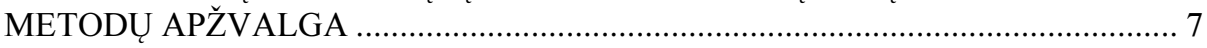

1.1. Plačiajuosčiu planariujų lètinimo sistemų modeliai ir tyrimas ............................... 7

1.2. Plačiajuosčių planariujų lètinimo sistemų taikymai ............................................. 10

1.3. Plačiajuosčių planariujų lètinimo sistemų tyrimams taikomi metodai ................. 17

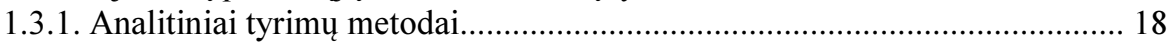

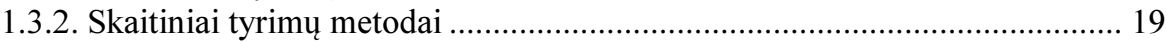

1.4. Autoriaus indèlis ị problemos sprendimą ...................................................... 23

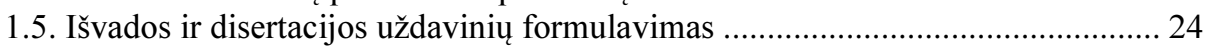


2. MEANDRINIŲ LĖTINIMO SISTEMŲ SU PAPILDOMAIS EKRANAIS MODELIŲ SUDARYMAS

2.1. Meandrinių lettinimo sistemų su papildomais ekranais kompiuteriniai modeliai. 28 2.1.1. Meandrinès lètinimo sistemos su skirtingais papildomų ekranų įžeminimo taškais

2.1.2. Meandrinès lètinimo sistemos su modifikuotomis kraštų topologijomis...... 31

2.2. Meandrinių letinimo sistemų su papildomais ekranais modelių tyrimas ............. 34

2.2.1. Dažninių charakteristikų apskaičiavimo algoritmas ..................................... 34

2.2.2. İejimo varžos nustatymo metodika ............................................................. 37

2.3. Elektrinio lauko meandrinèse lètinimo sistemose trimačio pasiskirstymo

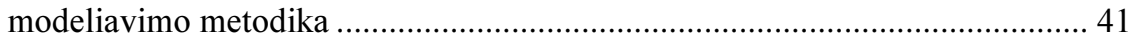

2.3.1. Momentų metodo taikymas ......................................................................... 41

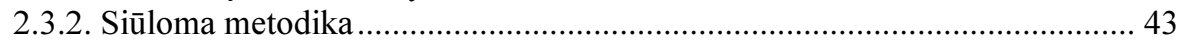

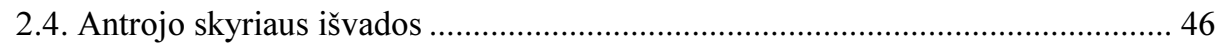

3. MEANDRINIŲ LĖTINIMO SISTEMU巳 SU PAPILDOMAIS EKRANAIS

SAVYBÉS

3.1. Papildomų ekranų įžeminimo taško įtakos sistemos dažninėms charakteristikoms

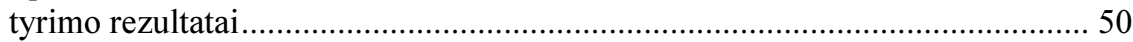

3.2. Kraštų topologijų įtakos sistemos dispersinèms savybèms tyrimo rezultatai ...... 56

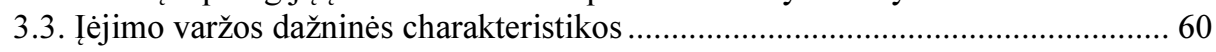

3.4. Elektrinio lauko meandrinèse lètinimo sistemose trimačio pasiskirstymo tyrimo

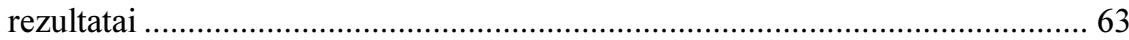

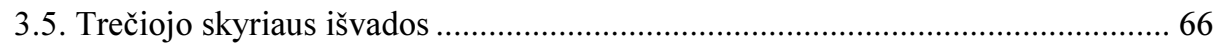

4. MEANDRINIŲ LĖTINIMO SISTEMŲ SU PAPILDOMAIS EKRANAIS

PARAMETRINE SINTEZĖ

4.1. Specializuotų programų paketų taikymo meandrinių lètinimo sistemų parametrinei sintezei galimybių analizè.

4.2. Meandrinių lètinimo sistemų su papildomais ekranais konstrukcinių parametrų

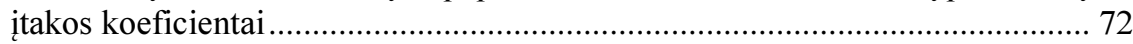

4.2.1. Konstrukciniu parametrų itaka sistemos fazinei vèlinimo trukmei ............... 74

4.2.2. Konstrukcinių parametrų įtaka sistemos įejjimo varžai ................................. 76

4.2.3. Konstrukcinių parametrų ịtaka sistemos praleidžiamųjų dažnių juostos

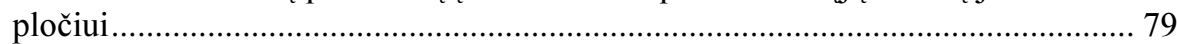

4.3. Meandrinių lètinimo sistemų su papildomais ekranais parametrinès sintezès

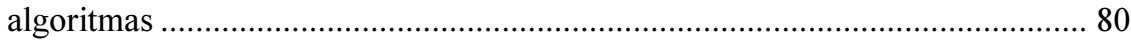

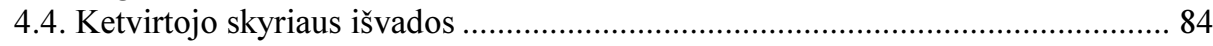

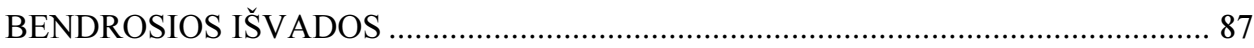

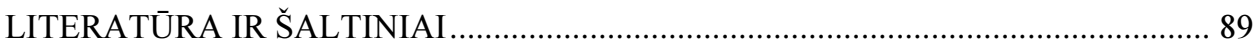

AUTORIAUS MOKSLINIŲ PUBLIKACIJŲ DISERTACIJOS TEMA SĄRAŠAS ..... 97 


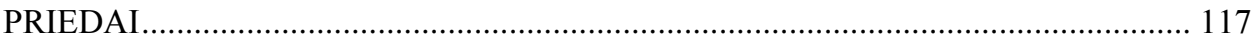

A priedas. Bendraautorių sutikimai teikti publikacijų medžiagą disertacijoje ......... 119

B priedas. Autoriaus mokslinių publikacijų disertacijos tema kopijos...................... 123 



\section{Contents}

INTRODUCTION ....

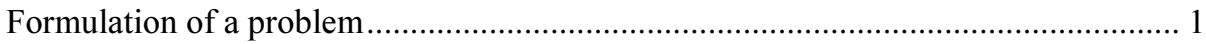

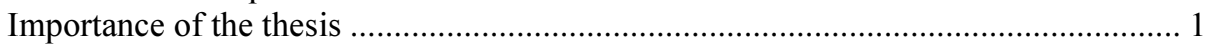

The object of research ........................................................................................ 2

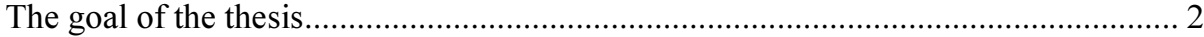

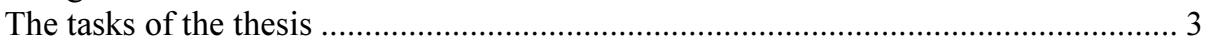

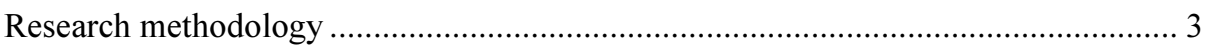

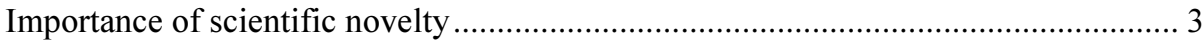

Practical significance of achieved results ................................................................ 4

The defended statements ......................................................................................... 4

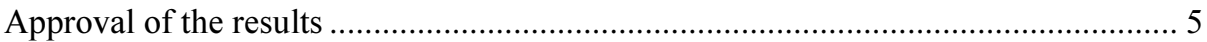

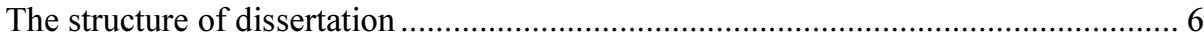

1. REVIEW OF BROADBAND PLANAR SLOW-WAVE SYSTEMS AND THEIR

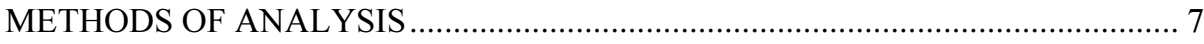

1.1. Models of broadband planar slow-wave systems and their research ..................... 7

1.2. Application areas of broadband planar slow-wave systems ……........................ 10

1.3. Methods for the research of broadband planar slow-wave systems .................... 17

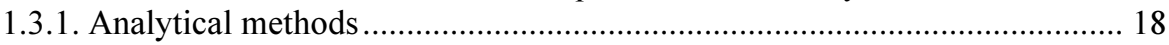

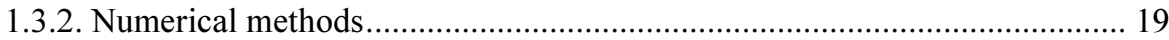

1.4. Author's contribution to the solution of the problem .......................................... 23

1.5. Conclusions of the chapter 1 and formulation of thesis tasks.............................. 24 
2. MODELS OF MEANDER SLOW-WAVE SYSTEMS WITH ADDITIONAL SHIELDS

2.1. Computer models of meander slow-wave system with additional shields .......... 28

2.1.1. Meander slow-wave systems with different grounding points of additional shields

2.1.2. Meander slow-wave system with different topologies of edges .................... 31

2.2. Research technique of meander slow-wave system with additional shields........ 34

2.2.1. Algorithm for calculation of frequency characteristics …………................ 34

2.2.2. Technique for estimation of input impedance …………............................. 37

2.3. Technique for evaluation of $3 \mathrm{D}$ distribution of electrical field in meander slow-

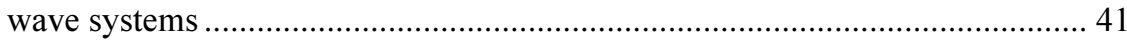

2.3.1. Application of the moment method .......................................................... 41

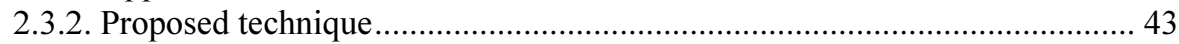

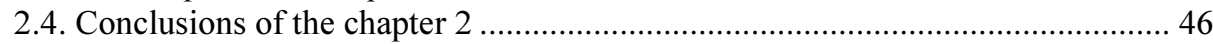

3. CHARACTERISTICS OF MEANDER SLOW-WAVE SYSTEMS WITH

ADDITIONAL SHIELDS

3.1. Influence of grounding point of additional shield on frequency characteristics of

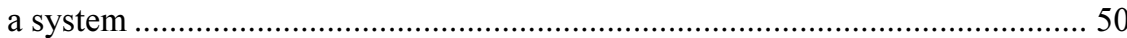

3.2. Influence of different topologies of edges on dispersion characteristics of a

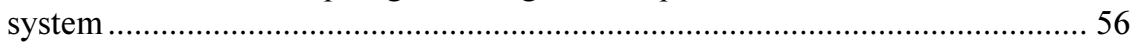

3.3. Frequency characteristics of the input impedance.............................................. 60

3.4. Research results of 3D distribution of electrical field in meander slow-wave

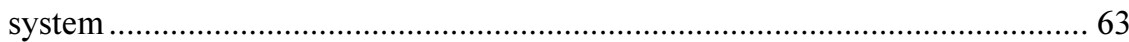

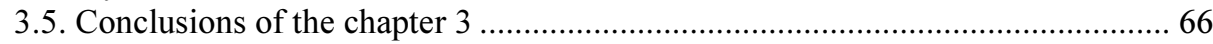

4. PARAMETRIC SYNTHESIS OF MEANDER SLOW-WAVE SYSTEM WITH

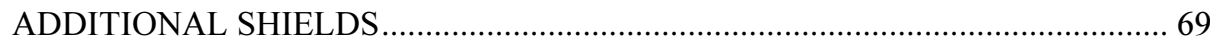

4.1. Analysis of possibilities of application of EM software for the parametric synthesis of meander slow-wave systems

4.2. Influence coefficients of constructive parameters of meander slow-wave systems

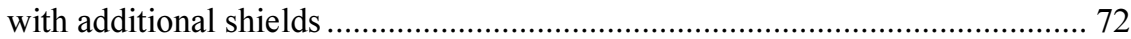

4.2.1. Influence of constructive parameters on phase delay time .......................... 74

4.2.2. Influence of constructive parameters on input impedance .......................... 76

4.2.3. Influence of constructive parameters on bandwidth ...................................... 79

4.3. Algorithm for parametric synthesis of meander slow-wave system with

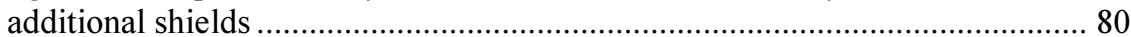

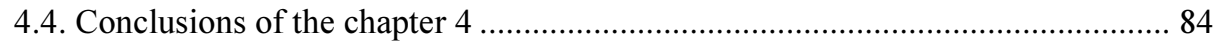

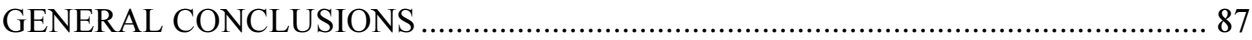

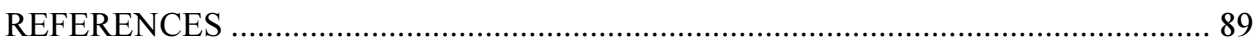

LIST OF THE AUTHOR`S SCIENTIFIC PUBLICATIONS RELATED TO THE

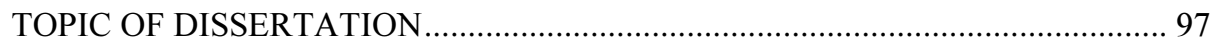




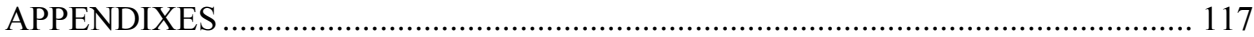

Appendix A. The co-authors agreement to present publications .............................. 119

Appendix B. Copies of authors scientific publications on the subject of dissertation 



\section{Ivadas}

\section{Problemos formulavimas}

Iprastoje meandrinejje lètinimo sistemoje fazinio vèlinimo trukmė labai priklauso nuo signalo dažnio - signalo dažniui didejjant vèlinimo trukmè didejja. To priežastis yra nuo dažnio priklausantis elektromagnetinis ryšys tarp gretimų meandro laidininkų. Siekiant sumažinti elektromagnetinę sąveiką, tarp gretimų meandro laidininkų įterpiami papildomi ekranai, kurie trumpikliais sujungiami su išoriniu ekranu.

Meandrinių lètinimo sistemų analizei dažnai taikomi analitiniai analizès metodai. Šie metodai neleidžia įvertinti meandro formos laidininko kraštuose bei galuose vykstančius procesus. Procesus meandro kraštuose bei galuose galima ivertinti naudojant skaitiniais metodais grịstus modelius.

Disertacijoje sprendžiama papildomų ekranų įtakos meandrinių lètinimo sistemų dažninèms savybèms įvertinimo problema.

\section{Darbo aktualumas}

Meandrinès lètinimo sistemos yra plačiai taikomos antenose, monolitiniuose mikrobangų integriniuose grandynuose ir didelio duomenų perdavimo greičio 
skaitmeniniuose įtaisuose. Filtrai, šakotuvai ir galios dalikliai gali būti pagaminti taikant meandrines lètinimo sistemas, kuriu gamybos procesas yra pigus ir paprastesnis negu įprastinių bangolaidinių struktūrų gamyba.

Pirmosios meandrinès lètinimo sistemos atsirado šeštajame $\mathrm{XX}$ a. dešimtmetyje. Jų modeliai buvo sudaromi taikant analitinius metodus. Pavyzdžiui, ekvivalentiniu grandinių metodu sudaryti modeliai gauti su ịvairiomis prielaidomis sprendžiant elektrodinaminị uždavinị. Tačiau taikant šį metodą, neįmanoma nustatyti elektrinio lauko sandaros lètinimo sistemoje, be to jis galioja tik tam tikrame, ribotame dažnių ruože. Vèliau ịvairaus sudètingumo modeliai buvo sudaromi taikant daugialaidžių linijų metodą. Šiuo metodu dažniausiai modeliuojamos begalinio ilgio sistemos, todèl juo negalima ịvertinti galų efekto. $\mathrm{XX}$ a. pabaigoje tobulèjant kompiuterinei technikai, buvo sukurti pirmieji komerciniai elektromagnetinių laukų sprendimo programų paketai, pagrịsti skaitiniais metodais, kurie tinka lètinimo sistemu projektavimui. Šie paketai leidžia sukurti tikslius sudètingų lètinimo sistemų modelius.

Iprastose meandrinèse lètinimo sistemose nuo dažnio priklausantis elektromagnetinis ryšys tarp gretimų meandro laidininkų turi įtakos fazinei vẻlinimo trukmei. Siekiant sumažinti elektromagnetinę sąveiką, tarp gretimų meandro laidininkų ịterpiami papildomi ekranai, kurie trumpikliais sujungiami su išoriniu ekranu. Tokių meandrinių lètinimo sistemos su papildomais ekranais konstrukcija yra sudètinga, todèl tikslinga jas projektuoti taikant skaitiniais metodais grịstus modelius.

Elektromagnetinių bangų sklidimo procesai meandrinès lètinimo sistemos su papildomais ekranais kraštuose bei galuose turi įtakos jos dispersinėms savybèms. Be to, literatūroje nèra duomenų apie tokių sistemų ịejjimo varžos ir jos Sparametrų dažnines charakteristikas. Taigi, taikant specializuotus programų paketus, aktualu kurti naujus meandrinių lètinimo sistemų su papildomais ekranais modelius, leisiančius praplèsti jų darbo dažnių ruožo ribas, sumažinti vèlinimo trukmès dispersiją ir ịvertinti sistemos suderinamumą su signalų traktu.

\section{Tyrimų objektas}

Darbo tyrimų objektas - planariosios meandrinès lètinimo sistemos su papildomais ekranais, jų modeliai ir analizès bei sintezès metodai.

\section{Darbo tikslas}

Šio darbo tikslas yra ištirti planariąsias meandrines lètinimo sistemas su papildomais ekranais, sukurti naujus modelius ir jų tyrimo metodikas, leidžiančias 
ịvertinti lètinimo sistemų kraštų bei galų efektus, sukurti tokių lètinimo sistemų parametrinès sintezès metodiką.

\section{Darbo uždaviniai}

Tikslui pasiekti darbe reikia spręsti šiuos uždavinius:

1. Taikant momentų metodą, sudaryti elektrinio lauko meandrinèse lètinimo sistemose trimačio pasiskirstymo modeliavimo metodiką ir ištirti elektrinio lauko struktūrą planariosiose meandrinèse lètinimo sistemose.

2. Sudaryti planariųų meandrinių lètinimo sistemų su papildomais ekranais modelius, taikant specializuotus programų paketus.

3. Ištirti planariųų meandrinių lètinimo sistemų su papildomais ekranais kraštų bei galų efektų įtaką sistemos dispersinèms savybèms ir ièjimo varžos priklausomybei nuo dažnio.

4. Sukurti planariujų meandrinių lètinimo sistemų su papildomais ekranais parametrinès sintezès metodiką.

\section{Tyrimų metodika}

Darbe, elektrodinaminio uždavinio sprendimui taikomas momentų metodas. Meandrinių lètinimo sistemų su papildomais ekranais modeliai igyvendinami ir analizuojami taikant šiuo metodu gristu specializuotu programų paketu Sonnet ${ }^{\circledR}$, duomenų apdorojimui taikomas programų paketas Matlab ${ }^{\circledR}$.

\section{Darbo mokslinis naujumas}

Rengiant disertaciją buvo gauti šie elektros ir elektronikos inžinerijos mokslui nauji rezultatai:

1. Sukurta momentų metodu grista metodika elektrinio lauko plokščiosiose meandrinèse lètinimo sistemose trimačio pasiskirstymo modeliavimui ir gauti tyrimo rezultatai.

2. Sukurti bei igyvendinti planariujų meandrinių lètinimo sistemų su papildomais ekranais modeliai ir taikant momentų metodu grịstą spe- 
cializuotą programų paketą ištirta kraštų bei galų efektų įtaką sistemos vèlinimo trukmès dispersijai.

3. Sukurta metodika leidžianti nustatyti meandrinès lètinimo sistemos su papildomais ekranais iejjimo varžą ir tirti šios varžos dažnines savybes taikant momentų metodu grịstą specializuotą programų paketą Sonnet ${ }^{\circledR}$.

4. Atlikta meandrinių lètinimo sistemų su papildomais ekranais įžemintais iš abiejų galų elektrinių charakteristikų jautrumo konstrukcinių parametru keitimui analizè nustatant itakos koeficientus ir sudaryta tokių sistemų parametrinès sintezès metodika.

\section{Darbo rezultatụ praktinẻ reikšmè}

Sudaryta metodika leidžianti modeliuoti elektrinio lauko trimati pasiskirstymą meandrinèse lètinimo sistemose ir ịvertinti elektromagnetinį ryši tarp gretimų meandro laidininkų. Sukurti meandrinès lètinimo sistemos su papildomais ekranais modeliai, leidžiantys projektuoti lètinimo sistemas, įvertinant kraštuose bei galuose vykstančius elektromagnetinių bangų sklidimo procesus. Sukurta metodika, leidžianti nustatyti meandrinès lètinimo sistemos su papildomais ekranais iejjimo varžos dažnines charakteristikas, reikalingas sistemos suderinimo su signalu traktu ịvertinimui. Sukurta parametrinès sintezès metodika, leidžianti sintezuoti meandrinių lètinimo sistemų su papildomais ekranais įžemintais iš abiejų galų konstrukcinius parametrus pagal nustatytas sistemos elektrines charakteristikas.

\section{Ginamieji teiginiai}

1. Irrengus papildomus ekranus plokščiojoje meandrineje lètinimo sistemoje ir juos sujungus su išoriniu ekranu iš abiejų galų, sumažinama sistemos vẻlinimo trukmès dispersija, kuri dažnių ruože iki $1,97 \mathrm{GHz}$ neviršija $0,035 \mathrm{~ns}$.

2. Tarpo didinimas kraštuose ties meandro kilpomis didina sistemos vèlinimo trukmę, kuri žemuosiuose dažniuose gali būti suvienodinta mažinant juostelès ilgị $2 A$. Tokiu būdu, nekeičiant dispersinių savybių sumažinamas bendras sistemos užimamas plotas. Esant meandrinio laidininko ilgiui $19 \mathrm{~mm}$, tarpo pločiui $0,5 \mathrm{~mm}$ ir tarpo ilgiui $0,6 \mathrm{~mm}$, sistemos plotas sumažèja apie $3 \%$. 
3. Siūloma metodika tinka plokščiosios meandrinès lètinimo sistemos su papildomais ekranais iejjimo varžos nustatymui jos kraštuose bei viduryje. İejjimo varža kraštuose yra pastovi dažnių ruože iki $1,5 \mathrm{GHz}$, sistemos viduryje - iki $2 \mathrm{GHz}$, o jos vertė žemuosiuose dažniuose yra tokia pati kaip ir sistemos kraštuose.

4. Konstrukcinių parametrų įtakos koeficientais paremta meandrinių lètinimo sistemų su papildomais ekranais įžemintais iš abiejų galų parametrinès sintezès metodika leidžia automatizuotą tokių lètinimo sistemų projektavimą.

\section{Darbo rezultatụ aprobavimas}

Disertacijos tema yra atspausdinti 5 moksliniai straipsniai: trys - mokslo žurnaluose, itrauktuose $\mathfrak{i}$ Thomson Reuters Web of Knowledge duomenų bazę (Metlevskis, Urbanavičius 2011; Metlevskis, Martavičius 2011; Metlevskis, Martavičius 2014); vienas - mokslo žurnale, cituojamame kitose tarptautinèse duomenų bazése (Metlevskis 2012), vienas - recenzuojamoje tarptautinès konferencijos medžiagoje (Metlevskis, Martavičius 2012).

Disertacijoje atliktų tyrimų rezultatai buvo paskelbti aštuoniose mokslinėse konferencijose Lietuvoje ir užsienyje:

- Metlevskis, E. 2011. Plačiajuosčių planarinių lètinimo sistemų taikymai ir perspektyvos. Keturioliktoji respublikinė Lietuvos jaunųų mokslininkų konferencija „Mokslas - Lietuvos ateitis“. Vilnius, 2011 m. kovo $18 \mathrm{~d}$.

- Metlevskis, E., Martavičius, R. 2011. Computer Model of Shielded Meander Slow-wave System. Penkioliktoji tarptautine konferencija „Elektronika 2011“. Vilnius, 2011 m. gegužès 17-19 d.

- Metlevskis, E., Martavičius, R. 2011. Computer Models of Meander Slow-wave System with Addidional Shields. PhD Students and Young Scientists Conference. Varšuva, Lenkija, 2011 m., rugsèjo 19-22 d.

- Metlevskis, E. 2012. Meandrinès létinimo sistemos su kilpų pavidalo papildomais ekranais kraštų efektų tyrimo rezultatai. Penkioliktoji respublikinė Lietuvos jaunujų mokslininkų konferencija ,Mokslas - Lietuvos ateitis“. Vilnius, $2012 \mathrm{~m}$. kovo $16 \mathrm{~d}$.

- Metlevskis, E., Martavičius, R. 2012. Calculation of Characteristics of Meander Slow-wave System with additional shields. XXII International Conference on Electromagnetic Disturbances "EMD2012". Vilnius, $2012 \mathrm{~m}$. rugsèjo 20-21 d.

- Metlevskis, E. 2012. Investigation of Topology of Edges in Meander Slow-wave System with Additional Shields. Tarptautinis seminaras 
„Modern Microwave Devices and Systems“. Minskas, Baltarusija, $2012 \mathrm{~m}$. lapkričio $18 \mathrm{~d}$.

- Metlevskis, E. 2013. Meandrinių lètinimo sistemų su papildomais ekranais konstrukcinių parametrų ịtakos vélinimo laikui ir įèjimo varžai tyrimas. Šešioliktoji respublikinė Lietuvos jaunujų mokslininkų konferencija „Mokslas - Lietuvos ateitis“. Vilnius, 2013 m. kovo $15 \mathrm{~d}$.

- Metlevskis, E., Martavičius, R. 2013. Frequency Characteristics of the Input Impedance of Meander Slow-wave System with Additional Shields. Septynioliktoji tarptautinè konferencija "Elektronika 2013". Palanga, $2013 \mathrm{~m}$. birželio 17-19 d.

\section{Disertacijos struktūra}

Disertaciją sudaro ịvadas, keturi skyriai, bendrosios išvados, literatūros bei autoriaus publikacijų disertacijos tema sąrašai, santrauka anglų kalba.

Darbo apimtis yra 116 puslapių, neskaitant priedų, tekste panaudotos 38 numeruotos formulès, 50 paveikslų ir 7 lentelès. Rašant disertaciją buvo panaudota 115 literatūros šaltinių. 


\section{1}

\section{Plačiajuosčių planariujų lètinimo sistemų ir ju analizès metody apžvalga}

Skyriuje apžvelgiamos plačiajuosčių planariujų lètinimo sistemų (PPLS) konstrukcijos, jų taikymo sritys, pateikiama trumpa šių sistemų tyrimų istorija. Taip pat aptariami PPLS tyrimams taikomi analitiniai ir skaitiniai metodai ir ju panaudojimas elektromagnetiniams uždaviniams spręsti. Skyriaus pabaigoje formuluojami darbo tikslas ir uždaviniai.

\subsection{Plačiajuosčių planariụjų lètinimo sistemų modeliai ir tyrimas}

Mikrobangų įtaisuose panaudojama elektromagnetinio lauko ir elektronų sąveika. Bègančiosios ir atgalinès bangos lempose elektromagnetinès bangos ir elektronų pluošto greičiai turi būti suderinti. Kadangi elektronų greitis būna mažesnis už šviesos greiti, bėgančiosios bangos įtaisuose, siekiant suderinti bangos ir elektronų greičius, naudojamos sulètintos elektromagnetinès bangos. Bangoms 
lètinti naudojami lètinimo ịtaisai, dar vadinami lètinimo sistemomis (Štaras et al. 2010).

Lètinimo sistemos, kaip ir ilgosios linijos, išsamesnei analizei reikalingos jos parametrų ir charakteristikų išraiškos. Parametrai ir charakteristikos gaunami apdorojant eksperimentinių tyrimų rezultatus arba dažniau - kompiuterinių skaičiavimo rezultatus, kuriuos atlikti be analitinių išraiškų neįmanoma. Projektuojant ịvairius mikrobangu ịtaisus reikia atlikti daugybę skaičiavimų optimizuojant projektuojamo įrenginio parametrus.

Lygtys

$$
\begin{gathered}
u(z, t)=A f\left(t-\frac{z}{v_{\mathrm{f}}}\right)+B g\left(t+\frac{z}{v_{\mathrm{f}}}\right), \\
i(z, t)=\frac{1}{Z_{0}}\left[A f\left(t-\frac{z}{v_{\mathrm{f}}}\right)-B g\left(t+\frac{z}{v_{\mathrm{f}}}\right)\right],
\end{gathered}
$$

yra bendri sprendiniai, kurie parodo įtampos ir srovès pasiskirstymus ilgojoje linijoje be nuostolių. Čia $A$ ir $B$ - nežinomi koeficientai. Kaip matome ịtampos ir srovès (1.1) ir (1.2) lygtyse priklauso nuo parametru $v_{\mathrm{f}}$ ir $Z_{0}$. Parametras $v_{\mathrm{f}}$ yra vadinamas elektromagnetinès bangos sklidimo faziniu greičiu ir apibréžiamas kaip

$$
v_{\mathrm{f}}=\frac{1}{\sqrt{L_{1} C_{1}}},
$$

čia $L_{1}$ ir $C_{1}$ yra paskirstytieji ilgosios linijos parametrai, nusakantys perdavimo linijos ilgini induktyvumą ir talpą. Vienas svarbiausių lètinimo sistemų savybes apibūdinančių parametru yra $Z_{0}$, kuris vadinamas linijos charakteringuoju impedansu arba bangine varža ir apibrěžiamas taip:

$$
Z_{0}=\sqrt{\frac{L_{1}}{C_{1}}} .
$$

Banginès varžos priklausomybę nuo kampinio dažnio $\omega$ galima apskaičiuoti tam tikrame sistemos pjūvyje, kurio koordinatè $z$, iš ịtampos ir srovès santykio:

$$
Z_{0}(z, \omega)=\frac{U(z, \omega)}{I(z, \omega)} .
$$

Pasirinkus skerspjūvio tašką, kuriame skaičiuojama dažninė banginès varžos charakteristika, šis dydis gali būti interpretuojamas skirtingai: pavyzdžiui, siste- 
mos ièjime $(z=0)$ apskaičiuotą dydi galima interpretuoti kaip sistemos ièjimo varžą $Z_{\mathrm{IN}}$.

Kitas svarbus parametras yra lètinimo koeficientas $k_{\mathrm{L}}$, kuris rodo, kiek kartų bangos sklidimo fazinis greitis $v_{\mathrm{f}}$ mažesnis už šviesos greitį vakuume $\mathrm{c}_{0}$. Jis išreiškiamas formule:

$$
k_{\mathrm{L}}=\frac{\mathrm{c}_{0}}{v_{\mathrm{f}}}=\mathrm{c}_{0} \sqrt{L_{1} C_{1}} .
$$

Žinant sistemos lètinimo koeficientą, vèlinimo trukmę $t_{\mathrm{v}}$ galima apskaičiuoti taikant formulę:

$$
t_{\mathrm{v}}=\frac{L_{\mathrm{S}}}{\mathrm{c}_{0}} k_{\mathrm{L}},
$$

čia $L_{\mathrm{S}}$ - lètinimo sistemos ilgis.

Pagal savo struktūrą lètinimo sistemos skirstomos ị trimates ir planariąsias. Trimatèse lètinimo sistemose signalų laidininkas yra išdèstomas keliose plokštumose (Chua, Aditia 2013; Kim et al. 2008). Sukurtos ịvairios konstrukcijos trimatès lètinimo sistemos su iš esmès besiskiriančiomis savybèmis (Liu et al. 2013; Sumathy et al. 2013). Trimačių LS gamyba yra palyginti sudètinga. Lengvesniu gamybos procesu pasižymi planariosios lètinimo sistemos (Nguyen et al. 2013; Chua et al. 2011), kurių bendras bruožas - plokščia jų konstrukcija, todèl jos gaminamos pagal standartines integrinių grandynų technologijas arba naudojant savaiminio formavimosi technologinius procesus (Navickas 2013). Taikant šias technologijas, suformuojami ịvairių konstrukcijų meandriniai, juosteliniai bei mikrojuosteliniai lètinimo įtaisai. Mikrojuostelinèse meandrinèse lètinimo sistemose gali būti vienas arba du ištisiniai ekranai. Erdvę tarp meandrinio laidininko ir ekranų užpildo vienalytis arba sluoksniuotas magnetodielektrikas (Martavičius 1996).

Lètinimo sistemos buvo pradètos tirti penktajame XX a. dešimtmetyje (Kalmann 1946; Лошаков, Ольдерогге 1948). Šiuose darbuose buvo analizuojamos spiralinès vèlinimo linijos. Per kitus du dešimtmečius susiformavo lètinimo sistemų analizès teorijos pagrindai (Ширман, Вайнорис 1959), jos pradètos taikyti bėgančiosios bangos vamzdžiuose (Burklund 1961) ir kreipimo sistemose (Niklas, Wimpffen 1958). Vèliau atsirado darbų apie sudètingesnių konstrukcijų lètinimo sistemas ir jų taikymus (Kowalski 1974; Лошаков et al. 1980; RashedMohassel 1991).

Pirmujjų lètinimo sistemų tyrimams buvo taikomi analitiniai analizès metodai: konforminių pakeitimų (Wheeler 1964), ekvivalentinių schemų (Sato 1971) ir daugialaidžių linijų (Štaras, Skudutis 1996). Šie metodai tinka nesudètingos konstrukcijos sistemų uždaviniams dvimatēje erdvèje spręsti, tačiau yra neuni- 
versalūs - pasikeitus LS konstrukcijai, pagrindinių jos parametrų apskaičiavimui tenka sudarinèti naują sistemą apibrèžiantị matematinị modelị ir išvedinèti sistemos dispersinę lygtị.

Tobulëjant kompiuterinei technikai, XX a. pabaigoje lètinimo sistemu analizei vis dažniau buvo taikomi skaitiniai metodai. Tarp dažniausiai taikomu galima paminèti baigtinių skirtumų laiko srities (Zhewang et al. 1996), baigtinių elementų (Tanaka et al. 1994) ir momentų metodus (Ureel, De Zutter 1996). Be to, atsirado ir nauja hibridinių metodų grupe kurių esmè - išspręsti elektromagnetinị uždavini pasitelkus ịvairių metodų derinị. Pavyzdžiui taikant dirbtinių neuronų tinklus nustatyti letinimo sistemos parametrus pasinaudojus skaitiniais metodais sudaryta duomenų baze (Guney et al. 1999).

Lietuvoje lètinimo sistemų tyrimai buvo pradèti septintajame XX a. dešimtmetyje, Kauno politechnikos instituto Vilniaus filiale, kuris vèliau tapo Vilniaus Gedimino technikos universiteto Elektronikos fakultetu. Profesoriaus Zenono Vainorio iniciatyva suburta mokslininkų grupé sukūrẻ vieningą lètinimokreipimo sistemų analizès teoriją, ištyrè ir palygino daugelio šių sistemų charakteristikas ir savybes (Вайнорис et al. 1986). Prie elektrodinaminių LS tyrimo ir jų taikymo mikrobangu i itaisuose problemos sprendimo daug prisidejo profesoriai S. Štaras, R. Martavičius, R. Kirvaitis, J. Skudutis, V. Urbanavičius, docentai A. Gurskas, A. Jurjevas, V. Daškevičius. Pastaraisiais metais šia tematika buvo apgintos tris daktaro disertacijos (Pomarnacki 2011, Katkevičius 2013, Krukonis 2013). Lètinimo sistemų teoriniai ir eksperimentiniai tyrimai, jų gamybos ir taikymo problemos apibendrintos monografijoje (Štaras et al. 2012).

\subsection{Plačiajuosčių planariụjų lètinimo sistemụ taikymai}

Plačiajuostès planariosios lètinimo sistemos plačiai taikomos elektrodinaminėse vèlinimo linijose (VL) ir bėgančiosios bangos elektroniniuose vamzdžiuose (BBEV). Vèlinimo linijos gali būti naudojamos signalų sinchronizavimui didelio duomenu perdavimo greičio skaitmeniniuose itaisuose. Gerai suprojektuota VL turètų pasižymèti mažais nuostoliais, būti nedidelių matmenų. Konstrukcinių matmenų mažinimas dažnai pasiekiamas bent vieną VL laidininką sulankstant meandru. Apskritai meandrinių VL praleidžiamujų dažnių juosta prasideda žemuosiuose dažniuose (Martavičius 1996; Štaras et al. 2010), tačiau tokios sistemos pasižymi didele dispersija, kuria reikia mažinti, norint jomis perduoti plačiajuosčius signalus. Be to, dèl padidejjusios elektromagnetinès sąveikos tarp gretimų VL juostelių, sumažèja linijos vèlinimo trukmè ir skaitmeniniame įtaise atsiranda klaidos. VL matmenis gali būti sumažinti ir kitu būdu - užpildant jos skerspjūvị medžiagomis su didelèmis dielektrinėmis ir magnetinėmis skvarbo- 
mis. Tokiu būdu darbe (Prodromakis et al. 2007) nagrinèjama VL išdèstyta ant sluoksniuoto sintetinio pagrindo, kurio santykine efektyvioji dielektrine skvarba $\varepsilon_{\mathrm{reff}} \approx 2900$.

Atsiradus naujoms integriniu grandynų gamybos technologijoms, tokioms kaip sistema viename korpuse (angl. system in package), dielektriniu pagrindu dažnai pasirenkamas silicis. Tokiose sistemos vèlinimo grandinès gali būti ịgyvendinamos iš aktyvių arba pasyvių elementų. Nepaisant savo mažų matmenų, aktyvieji elementai suvartoja daugiau energijos ir yra mažiau atsparūs triukšmui, lyginant su pasyviaisiais elementais. Be to, pasyviųu komponentu gamyba yra paprastesnè ir pigesnè (Khajooeizadeh, Abhari 2006). Todèl vèlinimo linijų išdèstytų ant silicio padèklo analizé ir projektavimas yra plačiai aptarinèjamos darbuose (Hansuek et al. 2012) ir (Khajooeizadeh, Abhari 2008). Darbe (Khajooeizadeh, Abhari 2008) projektuojama meandrinè vélinimo linija ant metalasdielektrikas-puslaidininkis tipo pagrindo, kurios letinimo koeficientas siekia 4,5, esant $5 \mathrm{GHz}$ pralaidumo juostos pločiui.

Vèlinimo linijos taip pat taikomos antenų gardelèse. Iš pradžiu antenų gardelių sistemos buvo taikomos karineje pramoneje, bet vèliau rado pritaikymą ir komercinèse komunikacijų sistemose. Tokios sistemos patrauklios savo ultraplačiajuostiškumu ir galimybe reguliuoti kryptingumo diagramą elektroniniu

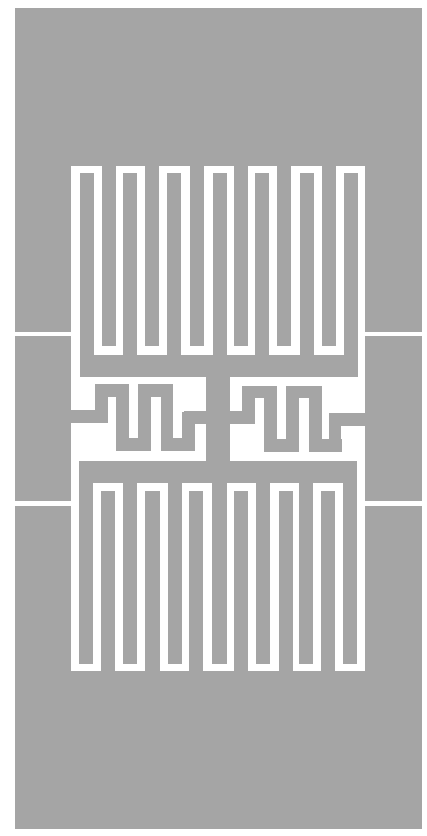

1.1 pav. Vèlinimo linijos celè (Shu-Yin, Wen-Jiao 2012)

Fig. 1.1. Delay line cell (Shu-Yin, Wen-Jiao 2012) 
būdu. Darbe (Shu-Yin, Wen-Jiao 2012) VL sudaroma iš 15 vienodų celių. Kiekvieną celę, kuri pavaizduota 1.1 paveiksle, sudaro komplanarusis bangolaidis. Ši planariosios konstrukcijos antenų gardelè yra pagaminta ant pigaus FR-4 pagrindo ir skirta dirbti 2,4 GHz dažnio ruože. Dar vienos vélinimo linijos, sudarytos iš komplanariojo bangolaidžio, projektavimas aptarinejjamas darbe (Jinglin et al. 2010). Ši linija ypatinga tuo, kad keičiant valdymo ịtampą, galima kontroliuoti jos fazinio vèlinimo trukmę. Vèlinimo linijos užimamas plotas yra $\operatorname{vos} 0,06 \mathrm{~mm}^{2}$.

Lètinimo sistema yra esminis ir būtinas bėgančiosios bangos įtaisu elementas (Vainoris 2004). Dẻl savo didelès galios ir efektyvumo, šie ịtaisai plačiai taikomi komercinèse antžeminèse ir palydovinèse komunikacijų sistemose (Cusick et al. 2012). Karinejje elektronikoje BBEV naudojami mikrobangu stiprinimui duomenų perdavimo kanaluose, radarų sistemose, elektroninėse apsaugos sistemose. Darbe (Trani, Antoine 2012) pristatomas karo pramonejje taikomas didelès galios mikrobangų stiprintuvas: $200 \mathrm{~W}$ esant $6-18 \mathrm{GHz}$ dažnių ruožui ir $80 \mathrm{~W}$ esant $18-40 \mathrm{GHz}$ dažnių ruožui. BBEV taip pat rado savo pritaikymą matavimų prietaisuose, elektroninių ginklų gamyboje.

Bègančiosios bangos elektroniniuose vamzdžiuose taikomos spiralinès (Chen et al. 2013; Chua et al. 2012) ir meandrinès (Wang et al. 2013) plačiajuostès planariosios lètinimo sistemos. Siekiant pagerinti BBEV savybes, naudojamos skirtingos formos meandro laidininkai, pavaizduoti 1.2 paveiksle.

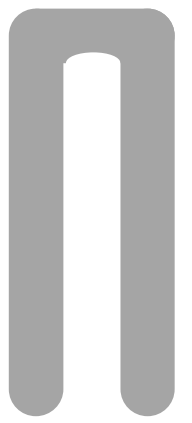

a)

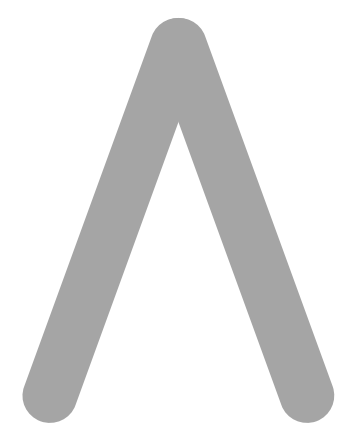

b)

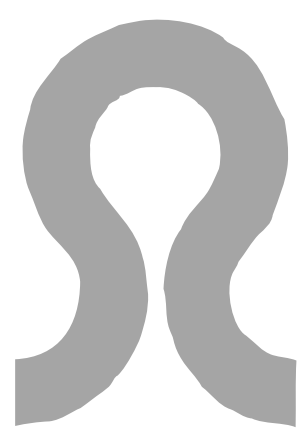

c)

1.2 pav. Skirtingos formos meandro laidininkai:

a) „U“ formos (Sengele et al. 2009); b) „V“ formos (Fei et al. 2012);

c) ,S“ formos (Bai et al. 2013)

Fig. 1.2. Meander conductors of different shapes: a) Ushaped (Sengele et al. 2009); b) V-shaped (Fei et al. 2012); c) S-shaped (Bai et al. 2013) 
Meandrinè lètinimo sistema su ịprastu arba „U“ formos laidininku (1.2 pav., a) pasižymi paprastesniu gamybos procesu (Sengele et al. 2009). BBEV, kuriose naudojamos lètinimo sistemos su , $\mathrm{V}^{\text {“ }}$ formos laidininku (1.2 pav., b) pasižymi didesne galia. Darbe (Fei et al. 2012) nagrinejjamas stiprintuvas, kurio išejimogalia yra $160 \mathrm{~W}$ esant $4700 \mathrm{~V}$ itampai ir $100 \mathrm{~mA}$ srovei. Taikant „S“ formos laidininką (1.2 pav., c), sistemos centrinis dažnis pasislenka į aukštesniujų dažnių sriti, tuo tarpu dispersinès savybės nepasikeičia. Be to, aukštesniujų dažnių srityje sumažeja perdavimo nuostoliai (Bai et al. 2013).

Plačiajuostès planariosios meandrinès lètinimo sistemos taip pat plačiai taikomos antenose, monolitiniuose integriniuose grandynuose ir didelio duomenu perdavimo greičio skaitmeniniuose įtaisuose. Filtrai, šakotuvai ir galios dalikliai gali būti pagaminti taikant meandrines lètinimo sistemas, kurių gamybos procesas yra pigus ir paprastesnis negu ịprastinių bangolaidinių struktūrų gamyba.

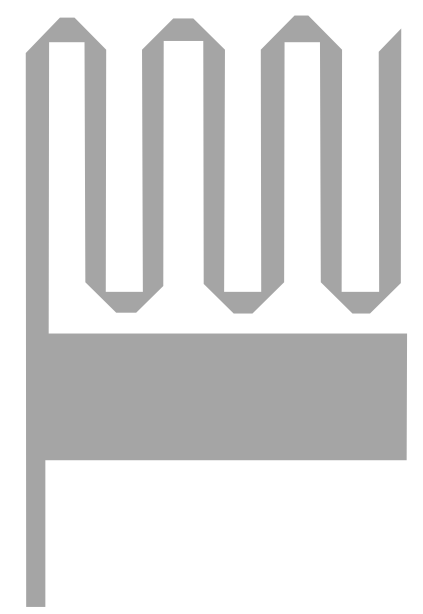

1.3 pav. Antenos dalis su meandro formos laidininku (Sultan et al. 2012)

Fig. 1.3. Meander line part of the antenna (Sultan et al. 2012)

Šiuo metu meandrinès lètinimo sistemos plačiausiai taikomos projektuojant antenas. Meandro formos laidininkas leidžia sumažinti antenos matmenis, todèl tokios antenos yra paplitusios mobiliuosiuose įrenginiuose (Amini, Hassani 2013). Darbe (Ban et al. 2013) antenos dali sudaro du meandro formos induktoriai, padedantys pasiekti $850 \mathrm{MHz}$ ir $900 \mathrm{MHz}$ rezonansini dažnį, kuriuo veikia GSM (angl. Global Standart for Mobile Communications) mobilusis ryšys. Be to, šiuolaikiniuose mobiliuosiuose įrenginiuose naudojamos antenos turi būti ne tik mažų matmenų bet ir veikti keliuose įvairius ryšio standartus atitinkančiuose dažnių ruožuose. Darbe (Sultan et al. 2012) projektuojama antena, kuri 
gali būti panaudota GSM, LTE (angl. Long Term Evolution), WiMAX (angl. Worldwide Interoperability for Microwave Access) ryšių standartus atitinkančiose sistemose, taip pat duomenų perdavimui per WLAN (angl. Wireless Local Area Network) bevielius lokalius tinklus. Taipogi, antena pasižymi maža savitaja sugertaja galia (angl. specific absorption rate), siejamą su bevielio ryšio sistemų poveikių žmonių sveikatai. Antenos dalis, kuria sudaro meandras pavaizduotas 1.3 paveiksle, skirta pasiekti $900 \mathrm{MHz}$ rezonansinį dažnį. Antenos matmenys $27 \times 25 \times 0,8 \mathrm{~mm}$.

Meandrinès lètinimo sistemos taip pat plačiai taikomos antenose, kurios skirtos radijo dažnio identifikavimo (angl. Radio Frequency IDentification RFID) sistemoms (Soliman et al. 2012; Ma et al. 2012). RFID technologija vis dažniau naudojama kasdienineje gyvenimo ir verslo aplinkoje. Jos panaudojimas yra labai platus - nuo medicinos iki logistikos. Vienas iš pagrindinių reikalavimų RFID sistemai - maži matmenys. Todèl darbe (Faudzi et al. 2013) projektuojamoje antenoje laidininkas yra sulankstomas meandru. Čia teigiama, kad meandro formos laidininko taikymas gali sumažinti antenos matmenis iki $70 \%$ palyginus su iprastine dipoline antena. Kitame darbe (Abdulhadi, Abhari 2012) projektuojamos RFID sistemoms skirtos antenos, dirbančios 860-960 MHz dažnių ruože. Viena iš antenu yra monopolinè, kitos, pavaizduotos 1.4 paveiksle, laidininkas sulankstytas meandru. Pastarosios antenos veikimo nuotolis $5,39 \mathrm{~m}$, o jos matmenys, kurie yra $28 \%$ mažesni už monopolinès antenos, siekia $42 \times 25,7 \mathrm{~mm}$.

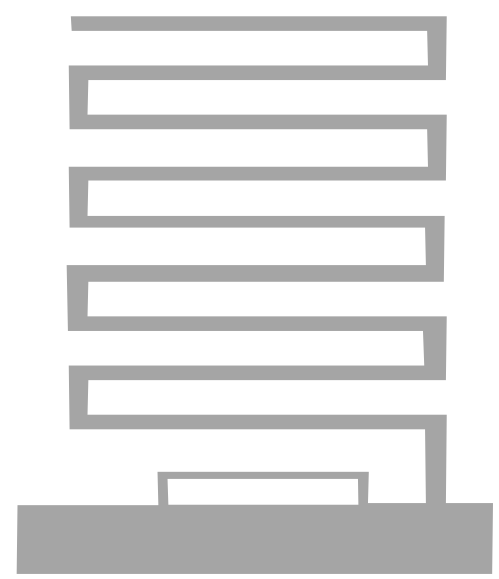

1.4 pav. Antenos, naudojamos radijo ryšio identifikavimo sistemose, eskizas (Abdulhadi, Abhari 2012)

Fig. 1.4. Structure of an antenna used in RFID systems (Abdulhadi, Abhari 2012) 
Kitą grupę įtaisų, kuriuose plačiai taikomos meandrinès lètinimo sistemos, sudaro filtrai. Darbe (Lin et al. 2012) panaudojant metalo oksido puslaidininkinę (angl. complementary metal oxide semiconductor - CMOS) technologiją, viršutiniame filtro sluoksnyje yra formuojamas meandro formos laidininkas, kuris yra rezonatorius. Linijos $50 \Omega$ banginè varža pasiekiama parenkant $10 \mu \mathrm{m}$ laidininko ploti.

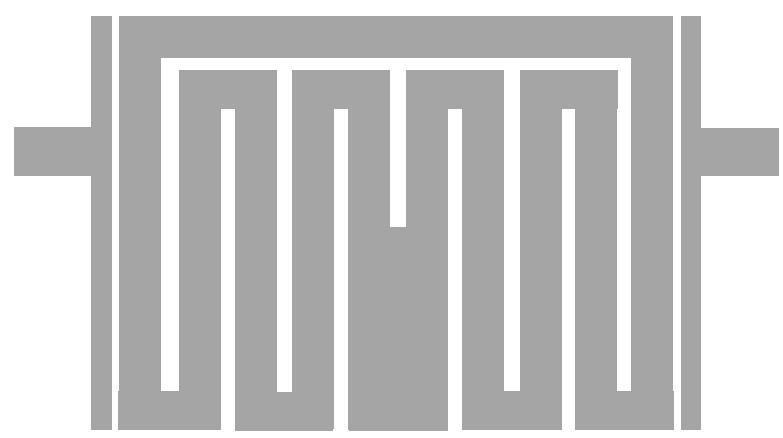

1.5 pav. Dviejų modu juostinio filtro eskizas (Gorur, Karpuz 2007)

Fig. 1.5. Structure of a dual-mode filter (Gorur, Karpuz 2007)

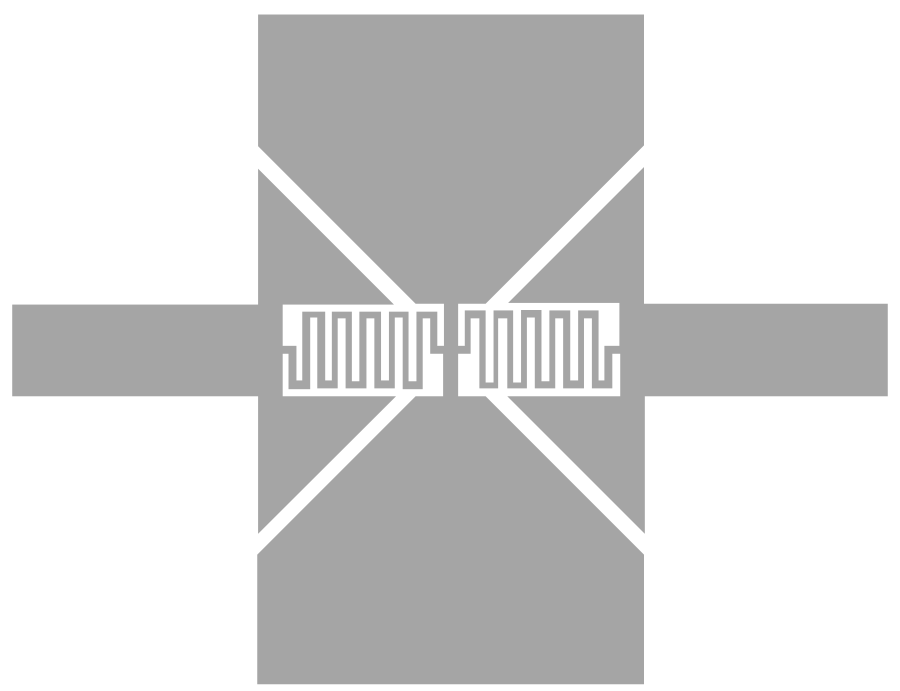

1.6 pav. Žemujų dažnių filtro eskizas (Ge et al. 2010)

Fig. 1.6. Structure of a low-pass filter (Ge et al. 2010) 
Filtrų gamybai taip pat naudojami aukštos temperatūros superlaidininkai (angl. high temperature superconductors - HTS). Tokie filtrai pasižymi žemais iejjimo nuostoliais ir aukštu perderinimu (Wang et al. 2013). Siekiant sumažinti dviejų modų juostinio filtro matmenis darbe (Gorur, Karpuz 2007) siūloma naudoti meandro formos rezonatorių. Toks filtras, pavaizduotas 1.5 paveiksle, taikomas palydoviniame ir mobiliajame ryšiuose. Projektuojamo rezonatoriaus centrinis dažnis yra 1,6 GHz. Filtro matmenys - 13,6×10,2 mm, jis yra gaminamas ant RT/Duroid dielektrinio pagrindo su skvarba $\varepsilon_{\mathrm{r}}=10,2$.

Meandro formos laidininkai taip pat naudojami projektuojant žemujų dažnių filtrus su plačia užtvaros juosta. Tokie filtrai naudojami komunikacijų sistemose harmonikų ir triukšmo signalų slopinimui. Darbe (Wang et al. 2010) aptariamas filtras, kuris pasižymi didesniu nei $15 \mathrm{~dB}$ slopinimu ruože nuo $1,8 \mathrm{iki} 8,84 \mathrm{GHz}$, o jo matmenys $-13,2 \times 13,2 \mathrm{~mm}$. Šiuo atveju meandras naudojamas perdavimo linijos ilgiui padidinti. Panašus filtras projektuojamas darbe (Ge et al. 2010). Šis filtras, pavaizduotas 1.6 paveiksle, turi itin plačią užtvaros juostą ir pasižymi didesniu nei $17 \mathrm{~dB}$ slopinimu bei mažesniu nei $0,3 \mathrm{~dB}$ įneštiniu slopinimu dažnių ruože nuo 2 iki 14,6 GHz. Filtro matmenys - 11×19 mm.

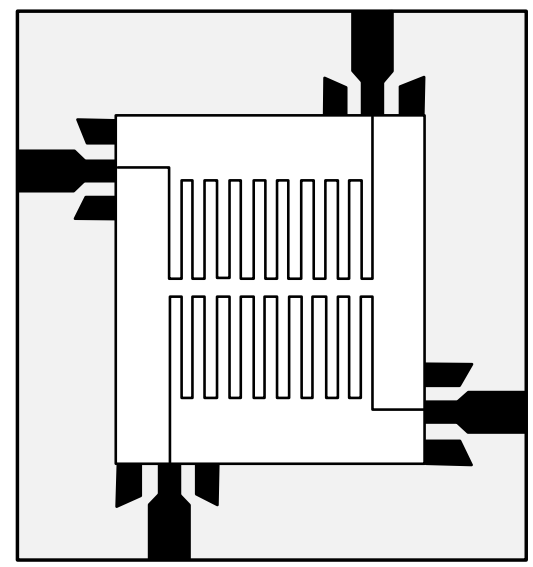

1.7 pav. Šakotuvo eskizas (Yang et al. 2006)

Fig. 1.7. Structure of a coupler (Yang et al. 2006)

Meandrinès lètinimo sistemos taip pat naudojamos šakotuvuose (Chiu et al. 2012). Darbe (Piekarz et al. 2012), taikant žematemperatūrès sukepintos keramikos (angl. low temperature co-fired ceramics - LTCC) technologiją, projektuojamas šakotuvas sudarytas iš susietujų meandrinių linijų. Čia teigiama, kad laidininko sulankstymas meandru padeda sumažinti ịtaiso matmenis: bendras meandrinès linijos ilgis $-8,64 \mathrm{~mm}$, tuo tarpu identiškų parametrų tie- 
saus laidininko ilgis yra 17,6 mm. Kitame darbe (Yang et al. 2006) kuriamas šakotuvas, sudarytas iš dviejų meandrinių linijų išdèstytų skirtinguose sluoksniuose. Toks įtaisas, pavaizduotas 1.7 paveiksle, gali būti taikomas monolitiniuose mikrobangų integriniuose grandynuose (maišikliuose, fazès keitikliuose, stiprintuvuose).

Fazès keitikliai plačiai taikomi fazinių gardelių sistemose spindulio valdymui ir formavimui. Darbe (Wu et al. 2012), keitiklio dali sudaro meandrinè linija, kurios matmenys $18 \times 18 \mathrm{~mm}$. Toks fazinis keitiklis skirtas dirbti $1-6 \mathrm{GHz}$ dažnių ruože. Taip pat vis labiau populiarejja fazès keitikliai gaminami ant skystujų kristalų pagrindo ir dirbantys $60 \mathrm{GHz}$ dažnių ruože (Deo et al. 2013; Bulja et al. 2010). Pagrindinis tokių keitiklių privalumas - galimybè valdyti juos išorine itampa.

Apibendrinant galima teigti, kad planariosios lètinimo sistemos plačiai taikomos ịvairiose srityse. Jų konstrukcija yra labai įvairi ir priklauso nuo įtaiso paskirties. Esamos konstrukcijos yra nuolat tobulinamos, nes mikrobangu įrenginiams keliami vis aukštesni reikalavimai. Šiame darbe pagrindinį dèmesi skirsime plačiajuostèms meandrinèms lètinimo sistemoms, kurių praleidžiamųjų dažniu juosta prasideda žemuosiuose dažniuose. Tokios sistemos pasižymi didele dispersija, kuria reikia mažinti, norint jomis perduoti plačiajuosčius signalus. Dispersija gali būti sumažinta įtaisant papildomus ekranus tarp gretimų meandro laidininko juostelių.

\subsection{Plačiajuosčių planariụjų lètinimo sistemų tyrimams taikomi metodai}

Plačiajuosčių planariujų lètinimo sistemų tyrimams taikomus metodus galima suskirstyti $\mathfrak{i}$ analitinius ir skaitinius. Analitinių metodų galimybės sprendžiant praktinius elektromagnetizmo uždavinius yra gana ribotos, jie tinka tik nesudètingos konstrukcijos sistemų uždaviniams dvimatèje erdvèje spręsti. Tobulëjant kompiuteriams, atsivèrè naujos galimybès - inžinerinejje praktikoje ir moksliniuose tyrimuose buvo pradèti taikyti skaitiniai metodai. Šiuos metodus taiko ir tobulina daugelio sričiu mokslininkai. Elektros ir elektronikos inžinerijos moksle, ypač elektrodinamikoje ir mikrobangu technikoje, skaitiniai metodai buvo pradèti taikyti maždaug prieš 40 metụ (Štaras 2008).

Pirmieji lètinimo sistemų modeliavimo metodai buvo kvazistatiniai. Taikant šiuos metodus manoma, kad struktūroje sklindanti moda nèra grynai TEM (angl. Transverse Electromagnetic Wave) - skersinè elektromagnetinè banga, o kvazi-TEM. Terminu „kvazi-TEM“ pabrěžiama, kad laukų struktūra lètinimo sistemoje dèl aplinkos, kurią dažniausiai sudaro keli dielektrikų sluoksniai, nedaug skiriasi nuo TEM bangos laukų. Dažnių srityje iki $10 \mathrm{GHz}$, tokia prielaida 
garantuoja pakankamą tikslumą, tačiau didejjant dažniui vis labiau pasireiškia išilginè dedamoji, kuri keičia modeliavimo rezultatus. Pavyzdžiui, išryškèja dispersija, t. y. pasireiškia pagrindinių sistemos parametrų priklausomybè nuo dažnio.

Vèliau lètinimo sistemų tyrimams buvo pradèti taikyti visabangès (angl. full-wave) analizès metodai. Šiuo atveju daroma prielaida, kad sklindanti banga yra hibridine, kas labai sugriežtina sistemos parametrų skaičiavimą. Svarbi visabangès analizès dalis yra tai, kad pagrindiniai lètinimo sistemos parametrai priklauso nuo dažnio.

\subsubsection{Analitiniai tyrimų metodai}

XX a. septintajame dešimtmetyje lètinimo sistemų parametrams skaičiuoti buvo pritaikytas konforminių pakeitimų metodas. Šis metodas leidžia gauti tiesiogines išraiškas, pagal kurias apskaičiuojami pagrindiniai lètinimo sistemos parametrai. Paprasčiausių mikrojuostelinių struktūrų analizès, taikant konforminių keitimų metodą, išraiškos buvo gautos dar 1964 metais. Tačiau šis metodas yra taikomas ir iki šiol. Darbe (Abbosh 2009) nagrinèjamos tris skirtingos susietuju mikrojuostelinių linijų konfigūracijos. Čia gaunamos išraiškos, leidžiančios apskaičiuoti banginę varžą esant lyginio ir nelyginio sužadinimo darbo režimams. Siekiant patvirtinti išraiškų tikslumą, jos yra panaudojamos projektuojant $3 \mathrm{~dB}$ šakotuvą. Taip pat galima išskirti darbą (Sadiku et al. 2007), kuriame palyginamos dvylikos skirtingu autorių išraiškos, leidžiančios apskaičiuoti mikrojuostelinių perdavimo linijų ilginę talpą, gautos per paskutinius keturis dešimtmečius. Konforminių pakeitimu metodas nereikalauja dideliu kompiuterinių išteklių bei iteracinių skaičiavimų, tačiau yra neuniversalus - pasikeitus lètinimo sistemos konstrukcijai, tenka atlikti vis naujus konforminius pakeitimus.

Plačiajuosčių planariųų lètinimo sistemų tyrimams taip pat taikomas ekvivalentinių schemų metodas. Šis metodas pagrịstas analizuojamosios lètinimo sistemos ekvivalentinès schemos iš pakopomis sujungtų keturpolių arba daugiapolių sudarymu. Kiekvienas daugiapolis susideda iš tarpusavio sujungtų sutelktụjų talpų ir induktyvumų, o taip pat ilgujjų linijų atkarpų. Sudarytoji ekvivalentinè grandinès schema analizuojama, taikant filtrų arba ilgujų linijų teoriją. Tai vaizdus metodas, tačiau jis neleidžia nustatyti elektrinio lauko struktūros vèlinimo linijoje. Be to, jis galioja tik tam tikrame, ribotame dažnių ruože. Sudètingiausia ekvivalentinių schemų metode tiksliai rasti ryši tarp nagrinejjamosios lètinimo sistemos konstrukcijos parametrų ir ekvivalentinès schemos elementu parametrų. Ekvivalentinèmis schemomis lètinimo sistemas modeliuoja (Olaode et al. 2012; Lin et al. 2009) darbų autoriai, kuriuose nagrinejjamos meandrinès vèlinimo linijos, taikomos projektuojant ịtaisus radijo ryšio sistemoms. Darbe (Das et al. 2011) teigiama, kad meandro formos laidininkai plačiai taikomos 
antenose, tačiau vis dar nèra paprasto analitinio modelio, aprašančio tokias sistemas. Todèl čia pateikiamas ekvivalentinèmis schemomis paremtas meandro formos antenos modelis, skirtas jos rezonansiniam dažniui apskaičiuoti.

Lètinimo sistemų analizei dažnai taikomas daugialaidžių linijų (DL) metodas. Daugialaidžių linijų metodo taikymas lètinimo sistemų modeliavimui plačiai aprašytas Lietuvos mokslininkų darbuose, kurie apibendrinti monografijoje (Štaras et al. 2010). Taikant ši metodą daroma prielaida, kad vienalyteje analizuojamosios planariosios lètinimo sistemos skerspjūvio srityje egzistuoja tik TEM banga. Aukštesnieji TE ir TM bangų tipai atsiranda tik netolygumų vietose ir, esant nedideliems netolygumų ilgiams, nuslopsta. Vienalyte planariosios lètinimo sistemos sritis modeliuojama daugialaide linija, o netolygumai - ekvivalentinėmis sutelktosiomis varžomis (Katkevičius 2010). Modelio daugialaidè linija - tai begalinių lygiagrečių laidininkų gardelè, kurios skerspjūvio konstrukcija ir matmenys tokie kaip analizuojamoje lètinimo sistemoje. Planarioji lètinimo sistema sudaroma iš DL suformuojant kraštinių sąlygų lygtis, kurios aprašo DL laidininkų tarpusavio sujungimus. Matematinis planariosios lètinimo sistemos modelis DL metodu gaunamas apjungus lygtis apibūdinančias TEM bangos sklidimą DL laidininkuose ir kraštinių sąlygų lygtis ị lygčių sistemą (Pomarnacki et al. 2010). Planariosios lètinimo sistemos laidininkų skerspjūvio forma, matmenys, ekranai ir magnetodielektrikai jos konstrukcijoje ivertinami apskaičiuojant DL laidininkų banginius laidumus ir elektromagnetinès bangos sklidimo išilgai šių laidininkų greiț (Krukonis et al. 2013).

Banginiai laidumai gali būti apskaičiuoti taikant anksčiau minètus analitinius metodus. Tačiau šie metodai neleidžia nustatyti elektrinio lauko struktūros lètinimo sistemoje ir ịvertinti kraštų bei galų efektų sistemos dispersinèms charakteristikoms. Be to, dèl šiems metodams būdingu skaičiavimo neapibréžčių atsiranda tiriamujų įtaisų charakteristikų skaičiavimo netikslumai. Todèl sudètingų konstrukcijų, tokių kaip meandrinès lètinimo sistemos su papildomais ekranais, tyrimams analitiniai metodai netinka. Tikslesnius skaičiavimo rezultatus galima gauti plačiajuosčių planariųų lètinimo sistemų tyrimams pritaikius skaitinius metodus.

\subsubsection{Skaitiniai tyrimų metodai}

Elektrodinamikoje skaitiniais metodais sprendžiamos Maksvelo, elektrostatikoje - Puasono ir Laplaso lygtys. Maksvelo lygtys gali būti užrašytos diferencialine ir integraline formomis. Todèl yra dvi skaitmeninių metodų grupès. Pirmosios grupès metodais sprendžiamos diferencialinès lygtys su dalinèmis išvestinèmis. Šiai grupei priklauso tokie metodai:

- baigtinių skirtumų metodas - BSM (angl. finite difference methodFDM); 
- baigtinių elementų metodas - BEM (angl. finite element methodFEM);

- baigtinių skirtumų laiko srities metodas - BSLS (angl. finite difference time domain - FDTD).

Antrosios grupès metodai taikomi integralinèms lygtims spręsti. Vienas svarbiausių šios grupés metodų - momentų metodas - MOM (angl. method of moments - MoM).

Pirmasis iš skaitinių metodų elektromagnetiniams uždaviniams spręsti buvo pritaikytas baigtinių skirtumų metodas. Šis metodas, kuris iš pradžių buvo vadinamas kvadratų metodu, buvo sukurtas trečiajame XX a. dešimtmetyje ir naudojamas netiesinems hidrodinamikos lygtims spręsti (Thom, Apelt 1961). Baigtinių skirtumų metodika remiasi aproksimacijomis, kurios leidžia diferencialines lygtis keisti baigtinių skirtumų lygtimis. Aproksimacijos šiuo atveju yra algebrinio pavidalo; jos nusako ryši tarp taško, esančio analizuojamoje srityje ir greta esančių taškų. Tokiu būdu, baigtinių skirtumų metodas iš esmès apima šiuos žingsnius:

1. Analizuojamos srities padalinimas ị mazgų tinklelị.

2. Diferencialinè lygtis išreiškimas ekvivalentiška baigtinių skirtumų lygtimi, kuri susieja kintamajị tam tikrame analizuojamos srities taške su greta esančiais taškais.

3. Skirtuminès lygties sprendimas nurodytoms ribinèms ir (arba) pradinèms sąlygoms.

Baigtinių skirtumų metodas elektromagnetinių uždavinių sprendimui buvo plačiau taikomas paskutiniame XX a. dešimtmetyje. Galima išskirti darbus, skirtus įvairių mikrojuostelinių struktūrų banginés varžos nustatymui (Rosales, Suster 1995; Bhattacharjee et al. 1995; Radhakrishnan, Chew 2000), mikrojuostelinių linijų analizei (Cantaragiu 1999). Tačiau šis metodas aptinkamas ir naujesniuose darbuose (Kui-Song et al. 2011). Čia BSM pritaikomas dviejų dalių antenų gardelès sklaidos parametrų apskaičiavimui.

Baigtinių elementų metodas - tai skaitinis metodas skirtas matematinèms fizikos diferencialinėms lygtims spręsti. Taikant baigtinių elementų metodą, galima spręsti ne tik elektromagnetinių bet ir mechaninių, termodinaminių, srautų bei kitokių fizinių sistemų uždavinius. Skirtingai nuo baigtinių skirtumų metodo, BEM nèra iteracinis metodas. Šio metodo teoriniai pagrindai yra sudètingesni, tačiau jis leidžia rasti apytikrị sprendinį iš karto - netaikant iteracijų. Norint spręsti elektrodinamikos uždavinius pasitelkus BEM, reikia žinoti elektromagnetinio lauko teoriją ir turèti programinę ịrangą, leidžiančią paprastai programuoti matricu apdorojimo veiksmus. 
Baigtinių elementų metodas taikomas darbe (He et al. 2012). Čia nagrinèjama meandro formos dipolinè antena, naudojama radijo dažnio identifikavimo sistemoje. Antenos rezonansinès savybès modeliuojamos ir tikrinamos programinès įrangos paketu HFSS $^{\circledR}$ (angl. high frequency structure simulator), kuris remiasi BEM. Śs paketas naudojamas ir darbe (Liu et al. 2012), kuriame projektuojama spiralinè lètinimo sistema bėgančios bangos elektroniniam vamzdžiui. BEM taip pat pritaikomas lètinimo sistemos slopinimo apskaičiavimui (Xu et al. 2012).

Elektromagnetinių uždavinių sprendimui plačiai taikomi laiko srities metodai. Vienas iš tokių metodų yra baigtinių skirtumų laiko srities metodas, kuris palyginti nesunkiai igyvendinamas programiškai, labai efektyvus ir lengvai adaptuojamas prie įvairių uždavinių. Sudètingesnių struktūrų analizei labiau tinka baigtinių elementų laiko srities metodas - BELS (angl. finite element time domain - FETD), tačiau BSLS leidžia naudoti tikslų laiko žingsni, kad padaro ji žymiai efektyvesniu nei BELS. Be to, programuojant BSLS metodą, nereikia saugoti matricų - tai sumažina kompiuterio atminties sąnaudas ir leidžia spręsti uždavinius su dideliu nežinomųjų skaičiumi (Bondeson et al. 2005). Baigtinių skirtumų laiko srities algoritmą 1966 metais pasiūlè K. S. Yee.

Baigtinių skirtumų laiko srities metodas pritaikomas meandro formos antenų optimizavimui (Watanabe et al. 2011), mikrojuostelinių linijų santykinès efektyviosios dielektrinès skvarbos priklausomybès nuo dažnio tyrimui (Krukonis, Urbanavičius 2011), taip pat ivvairių mikrobangų ịtaisų analizei (Lingjiang et al. 2012) ir trukdžių susietosiose perdavimo linijose įvertinimui (Mittal et al. 2012).

Analitinès matematikos integralinių lygčių sprendimo metodai yra sudètingi ir turi tam tikrų apribojimų. Iš taikomosios matematikos yra žinoma, kad integralas gali būti apytiksliai skaičiuojamas suma. Ši integralo savybè taikoma momentų metode - integravimas keičiamas sumavimu ir sudaroma tiesinių lygčių sistema, kurios sprendinys yra aproksimuota ieškoma funkcija. Metodo tikslumas iš esmès priklauso nuo demenų, kurių suma yra pakeičiamas integralas, skaičiaus. Pakankamai tikslių rezultatų radimas momentu metodu įmanomas tik naudojant kompiuteri, nes norint tiksliai rasti ieškomus dydžius reikia integralą dalinti ị dideli skaičiu (paprastai kelis šimtus) dėmenų ir matematinių veiksmų skaičius, priklausomai nuo analizuojamos sistemos, gali būti nuo dešimčių tūkstančių iki milijonų. Tokiu būdu elektromagnetinio uždavinio sprendimas momentu metodu atliekamas keturiais etapais:

1. Tinkamos integralinès lygties išvedimas.

2. Integralinès lygties pakeitimas matricine lygtimi naudojant skaidymo ir svorio funkcijas.

3. Matricos elementų nustatymas. 
4. Matricinių lygčių sprendimas ir reikiamų parametrų nustatymas.

Momentų metodas plačiai taikomas mikrobangų itaisų analizei ir projektavimui. Darbe (Sato et al. 2013) ieškoma optimalių meandro formos antenos parametrų taikant adaptyvų genetini algoritmą, tačiau jos iejjimo varža nustatoma taikant momentu metodą. Siekiant paspartinti skaičiavimus, darbe (Cerjanic et al. 2012) kompiuterinis kodas, skirtas antenu projektavimui, yra adaptuojamas grafiniams procesoriams (angl. graphics processing unit-GPU). Grafiniai procesoriai ypač tinka lygiagretiems skaičiavimams, kai ta pati programa yra suskaidoma ị daug duomenų elementų ir vykdoma lygiagrečiai. Tokiu būdu pasiekiamas didelis skaičiavimų našumas.

Šiuolaikiniai mikrobangų ịtaisams projektuoti skirti programinès įrangos paketai leidžia modeliuoti bei tirti sudètingus mikrobangu grandynus. Iš labiausiai paplitusiu galima paminèti COMSOL ${ }^{\circledR}, \mathrm{CST}_{\text {Microwave Studio }}{ }^{\circledR}$, Sonnet ${ }^{\circledR}$, HFSS $^{\circledR}$, QWED $^{\circledR}$, SPICE $^{\circledR}$. Šie paketai remiasi įvairiais skaitiniais metodais, o taip pat skiriasi savo sudettingumu, tikslumu bei pritaikymo galimybėmis. Pavyzdžiui programinès įrangos paketas Sonnet ${ }^{\circledR}$ remiasi momentu metodu (Rautio, Harrington 1987) ir yra ypatingai pritaikytas planariujų sistemu analizei, HFSS $^{\circledR}$ remiasi baigtiniu elementu metodu, QWED ${ }^{\circledR}$ - baigtiniu skirtumu laiko srities metodu, o CST Microwave Studio ${ }^{\circledR}$ ypač tinka trimačių sistemų analizei ir elektromagnetiniams uždaviniams spręsti leidžia pasirinkti vieną iš aukščiau išvardytų metodų.

Tiriant sudètingas elektrodinamines struktūras labai svarbu tinkamai pasirinkti skaitini metodą. Kaip jau buvo minèta, baigtinių skirtumų metodas yra iteracinis. Modeliuojant meandrines lètinimo sistemas su papildomais ekranais baigtinių skirtumų metodu, analizuojamą sritị tenka dalinti ị didelị mazgų skaičių. Dèl to gaunami didesni duomenų masyvai ir didejja iteracijų skaičius, o kartu ir skaičiavimo trukmè. Todèl šis metodas labiau tinka paprastesnių struktūrų tyrimui.

Universalesniu laikomas baigtinių elementų metodas. Tačiau jo teoriniai pagrindai yra sudètingesni, o uždavinio sprendimas labai priklauso nuo analizuojamos srities sudalinimo elementais procedūros. Šią procedūrą automatizuoti yra sunku, todèl baigtinių elementų metodas reikalauja daug kompiuterinių išteklių. Be to, BEM yra sunkiai igyvendinamas specializuotuose programu paketuose, modeliuoti meandrines lètinimo sistemas su papildomais ekranais šiuo metodu yra nepatogu.

Plačiajuosčiu meandrinių lètinimo sistemų tyrimams plačiausiai taikomi baigtiniu skirtumu laiko srities ir momentų metodai. BSLS metodas yra lankstesnis, lengviau igyvendinamas, nors ir reikalauja didesniu kompiuteriniu išteklių nei momentų metodas. Dél savo lankstumo BSLS metodas labiau tinkamas sklaidos problemoms spręsti. Analizuojant sudetingas elektrodinamines sistemas, tokias kaip meandrinès lètinimo sistemos su papildomais ekranais, tikslinga 
taikyti momentu metodą, nes tyrimai rodo, kad jis yra tikslesnis, sprendžiant tokio tipo uždavinius (Sheng, Song 2012). Todèl šiame darbe meandrinių lètinimo sistemų su papildomais ekranais modelių analizei pasirinktas momentų metodas ir juo gristas specializuotas programų paketas Sonnet ${ }^{\circledR}$.

\subsection{Autoriaus indèlis ị problemos sprendimą}

Mikrobangų įtaisuose naudojamos įvairių konstrukcijų plačiajuostės planariosios lètinimo sistemos. Plačia praleidžiamujjų dažnių juosta pasižymi spiralinès lètinimo sistemos (Skudutis, Daškevičius 2001). Tokių LS savybės yra nagrinėjamos ir tiriamos (Skudutis, Daškevičius 2002) ir (Štaras, Burokas 2003) darbuose. Siūlomi ir patobulinti spiralinių lètinimo-kreipimo sistemų modeliai (Štaras, Burokas 2004; Štaras, Burokas 2006). Taip pat galima paminèti darbus (Skudutis et al. 2004; Skudutis, Daškevičius 2006), kuriuose spiralinių lètinimo sistemų modeliavimui taikomi skaitmeniniai metodai ir naudojami tam skirti specializuoti programų paketai.

Disertacijoje plačiau nagrinejjamos meandrinès létinimo sistemos. Tokios sistemos svarbiausia dalis - meandro formos laidininkas (Martavičius, Urbanavičius 1996). Lietuvoje atlikta nemažai meandrinių lètinimo sistemų tyrimų: ištirtos būdingosios ir iejjimo varžų dažninès savybès (Martavičius, Urbanavičius 1997), laidininkų išilginių atkarpų itaka dažninèms charakteristikoms (Kleiza, Staras 1998), ekranų įtaka meandrinių vèlinimo linijų savybėms (Martavičius, Urbanavičius 1998). Gaminant meandro formos laidininką, juosteliu išdèstymo periode gali atsirasti žingsnio netolygumas. Todèl darbe (Martavičius, Urbanavičius 1999) yra ištirta žingsnio netolygumo įtaka meandrinių lètinimo sistemų savybėms.

Iprastoje meandrinèje lètinimo sistemoje fazinio vèlinimo trukmè labai priklauso nuo signalo dažnio - signalo dažniui didejjant vèlinimo trukmé didèja. To priežastis yra nuo dažnio priklausantis elektromagnetinis ryšys tarp gretimų meandro juostelių. Siekiant sumažinti elektromagnetinę sąveiką, tarp gretimų meandro laidininkų įterpiami papildomi ekranai, kurie trumpikliais yra sujungiami su išoriniu ekranu. Tokiu būdu sukurti meandrinès lettinimo sistemos su šukų (Martavičius, Jurjevas 1999) ir kilpų (Martavičius, Jurjevas 2000) pavidalo papildomais ekranais modeliai. Be to, pateikiami ir patikslinti plačiajuosčiu meandrinių LS su papildomais ekranais modeliai (Martavičius, Jurjevas 2001). Panašias konstrukcijas tiria ir užsienio autoriai (Nara, Koshiji 2006; Nara, Koshiji 2007).

Disertacijos autorius pasiūlè naujus meandrinių LS su papildomais ekranais modelius, ištyrè papildomų ekranų ižeminimo taško įtaką meandrinių LS dispersinėms savybėms. Taip pat nustatè meandro kraštų ịtaką sistemos dispersinėms 
savybèms. Be to, autorius pasiūlè meandrinių LS su papildomais ekranais įèjimo varžos nustatymo metodiką ir išanalizavo įejjimo varžos priklausomybę kintant dažniui.

\subsection{Išvados ir disertacijos uždavinių formulavimas}

Atlikus plačiajuosčių planariujų lètinimo sistemų ir jų analizès metodų apžvalgą galima teigti, kad:

1. Meandrinès lètinimo sistemos plačiai taikomos įvairiuose mikrobangų itaisuose: vèlinimo linijose, bėgančios bangos elektroniniuose vamzdžiuose, antenose, filtruose, šakotuvuose ir fazès keitikliuose.

2. Meandrinių lètinimo sistemų praleidžiamųų dažnių juosta prasideda žemuosiuose dažniuose. Tokios sistemos pasižymi didele dispersija, kuria reikia mažinti, norint jomis perduoti plačiajuosčius signalus. Todèl esamas meandrinių lètinimo sistemų konstrukcijas tenka tobulinti, norint pagerinti jų dispersines savybes. Dispersinès savybès gali būti pagerintos įtaisant papildomus ekranus tarp gretimų meandro laidininko juosteliu.

3. Lètinimo sistemu tyrimams taikomi analitiniai ir skaitiniai metodai. Analitiniai metodai neleidžia nustatyti elektrinio lauko struktūros lètinimo sistemoje ir ìvertinti kraštų bei galų efektų sistemos dispersinėms charakteristikoms. Todèl sudètingų konstrukcijų, tokių kaip meandrinès lètinimo sistemos su papildomais ekranais, tyrimams analitiniai metodai netinka. Tikslesnius skaičiavimo rezultatus galima gauti plačiajuosčių meandrinių lètinimo sistemų tyrimams pritaikius skaitinius metodus.

4. Modeliuojant lètinimo sistemas plačiausiai taikomi baigtinių skirtumų laiko srities ir momentu metodai. Tiriant sudetingas elektrodinamines struktūras momentų metodas yra tikslesnis, todèl šiame darbe meandrinių lètinimo sistemų su papildomais ekranais modeliai analizuojami taikant momentų metodą ir specializuotą programų paketą Sonnet ${ }^{\mathbb{R}}$.

Taigi aktualu kurti naujus plačiajuosčių planariujų lètinimo sistemų modelius, leisiančius ištirti galimybes praplèsti darbo dažnių ribas, sumažinti vẻlinimo trukmès dispersiją ir įvertinti sistemos suderinamumą su signalų traktu. Tam būtina taikyti specializuotus programinès įrangos paketus. Šiam tikslui pasiekti reikia išspręsti šiuos uždavinius:

1. Taikant momentų metodą, sudaryti elektrinio lauko meandrinèse lètinimo sistemose trimačio pasiskirstymo modeliavimo metodiką ir ištirti elektrinio lauko struktūrą plokščiosiose meandrinèse lètinimo sistemose. 
2. Sudaryti plokščiujų meandrinių lètinimo sistemų su papildomais ekranais modelius, taikant specializuotus programų paketus.

3. Ištirti plokščiųjų meandrinių lètinimo sistemų su papildomais ekranais kraštų bei galų efektų įtaką sistemos dispersinèms savybèms ir iejjimo varžos priklausomybei nuo dažnio.

4. Sukurti plokščiujų meandrinių lètinimo sistemų su papildomais ekranais parametrinès sintezès metodiką. 



\section{2}

\section{Meandrinių lètinimo sistemų su papildomais ekranais modeliu sudarymas}

Šiame skyriuje pasiūlomi nauji meandrinių lètinimo sistemų su papildomais ekranais kompiuteriniai modeliai, sukurti momentu metodu gristu specializuotu programų paketu Sonnet ${ }^{\circledR}$. Modeliai skiriasi papildomų ekranų ižeminimo taško vieta ir kraštų topologijomis. Meandrinių lètinimo sistemų su papildomais ekranais savybių tyrimui sudaromas sklaidos parametrų apskaičiavimo algoritmas ir iejjimo varžos nustatymo metodika. Be to, pasiūloma momentų metodu grịsta elektrinio lauko meandrinèse lètinimo sistemose trimačio pasiskirstymo modeliavimo metodika.

Skyriaus tematika paskelbti keturi autoriaus straipsniai (Metlevskis, Urbanavičius 2011; Metlevskis, Martavičius 2012; Metlevskis, Martavičius 2012; Metlevskis, Martavičius 2014). 


\subsection{Meandrinių lètinimo sistemų su papildomais ekranais kompiuteriniai modeliai}

Mikrobangu itaisų tyrimams vis dažniau taikomi specializuoti programų paketai, kurie leidžia kurti ivvairaus sudètingumo grandynų kompiuterinius modelius. Specializuotų programų paketų pagalba sukurti kompiuteriniai modeliai yra greitai ir lengvai modifikuojami, todèl atsiranda galimybè imitaciniu būdu tirti skirtingų konstrukcijų įtaisus išvengiant nemažai laiko trunkančio gamybos proceso.

Siame poskyryje, taikant momentų metodu grịstą specializuotą programų paketą Sonnet ${ }^{\circledR}$, sudaromi kompiuteriniai meandrinių lètinimo sistemų su papildomais ekranais modeliai. Sudarytuose modeliuose keičiamas papildomų ekranų ižžminimo taškas, o taip pat modifikuojamos kraštų topologijos.

\subsubsection{Meandrinès lètinimo sistemos su skirtingais papildomų ekranų įžeminimo taškais}

Meandrinè lètinimo sistema pavaizduota 2.1 paveiksle. Ją sudaro meandro formos laidininkas išdèstytas ant $h$ storio dielektrinio pagrindo, kurio santykiné dielektrinè skvarba $\varepsilon_{\mathrm{r}}$. Pagrindo apačia yra padegta laidžiuoju sluoksniu atliekančiu išorinio ekrano funkciją. Vienos laidininko juostelès ilgis žymimas $2 A$, plotis $w$. Tarpo tarp gretimų juostelių plotis žymimas $s$.

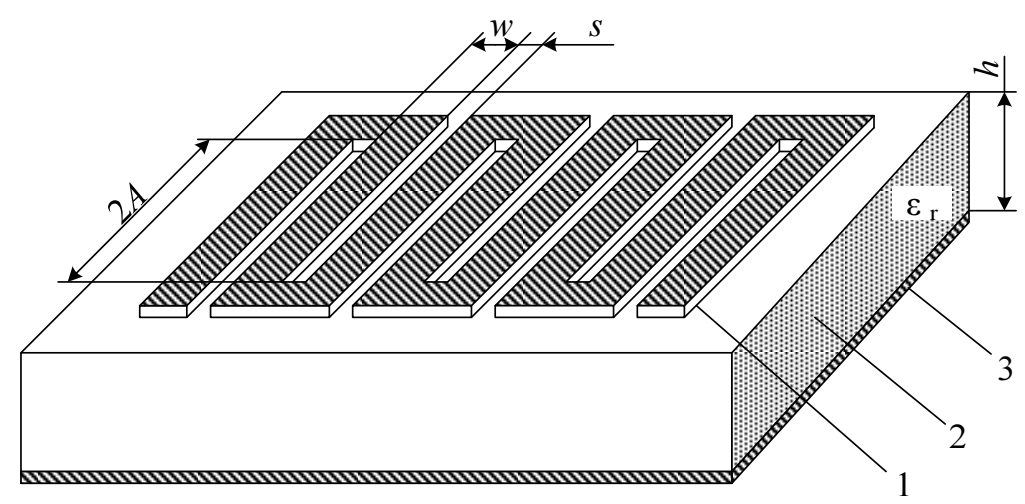

2.1 pav. Meandrinè lètinimo sistema: 1 - meandro formos laidininkas; 2 - pagrindas, kurio santykinė dielektrinė skvarba $\varepsilon_{\mathrm{r}} ; 3$ - išorinis ekranas

Fig. 2.1. Meander slow-wave system: 1 - meander-shape conductor; 2 - dielectric substrate of relative permittivity $\varepsilon_{\mathrm{r}} ; 3$ - external shield 
Meandrine lètinimo sistema sklindantys plačiajuosčiai signalai yra iškreipiami dèl fazinès vèlinimo trukmès dispersijos, kurios priežastis yra nuo dažnio priklausantis elektromagnetinis ryšys tarp gretimų meandro juostelių. Siekiant mažinti dispersiją, meandrinèse lètinimo sistemose naudojami papildomi ekranai, įtaisomi tarp meandrinio laidininko juostelių. Kai lètinimo sistemos gaminamos naudojant standartinę integrinių grandynų technologiją, šie papildomi ekranai gaminami kartu su meandriniu laidininku ir yra siaurų laidžių juostelių formos (Štaras et al. 2010).

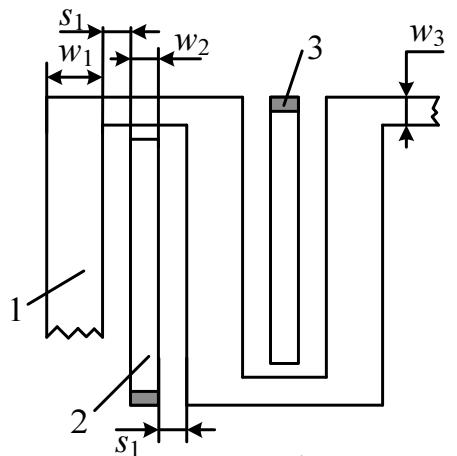

a)

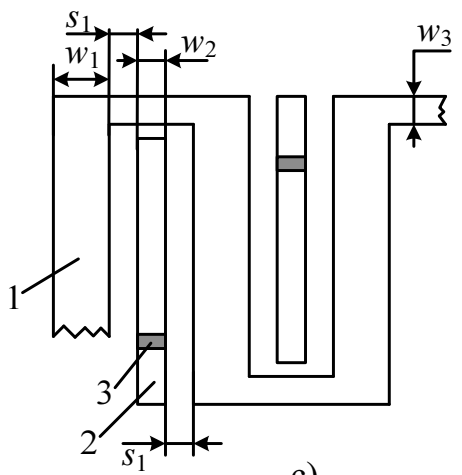

c)

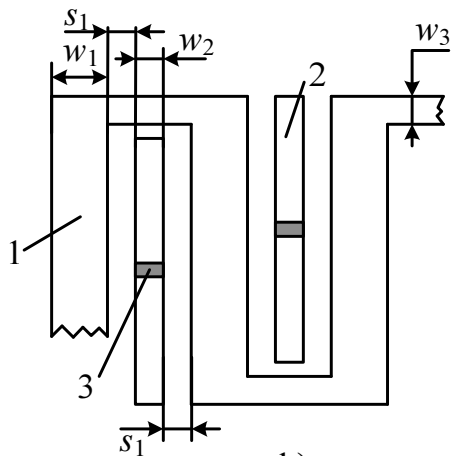

b)

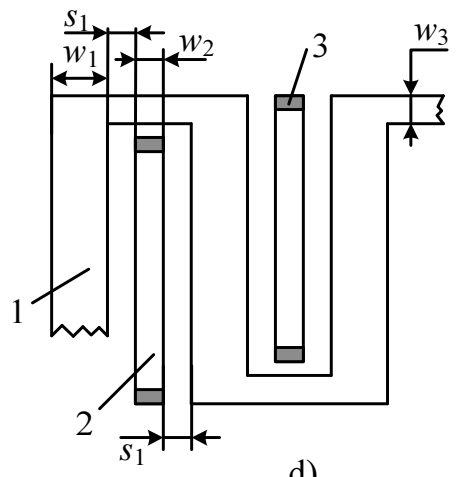

d)

2.2 pav. Meandrinių lètinimo sistemų topologijos, kai papildomi ekranai ižeminti: a) - viename gale; b) - viduryje; c) - taške tarp ekrano galo ir vidurio; d) - iš abiejų galų; 1 - meandro formos laidininkas; 2 - papildomas ekranas; 3 - trumpiklis

Fig. 2.2. Topology of meander slow-wave system with additional shields grounded at: a) - one edge; b) - center; c) - point between the edge and center; d) - both edges; 1 - meander-shape conductor; 2 - additional shield; 


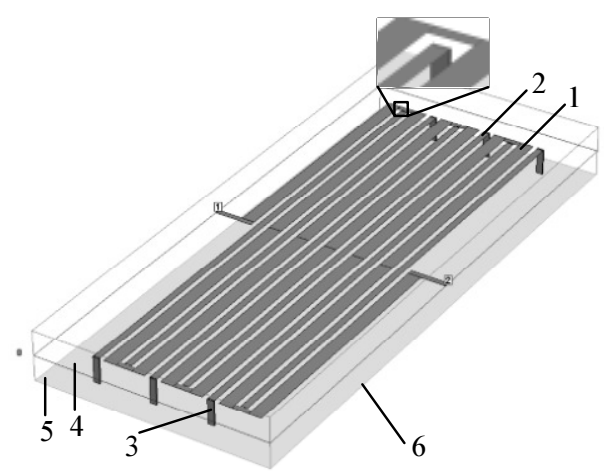

a)

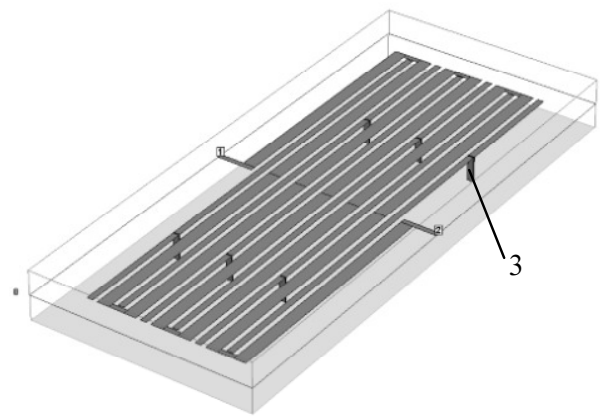

c)

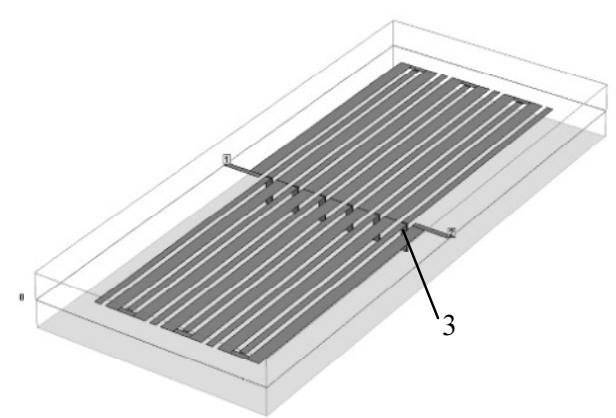

b)

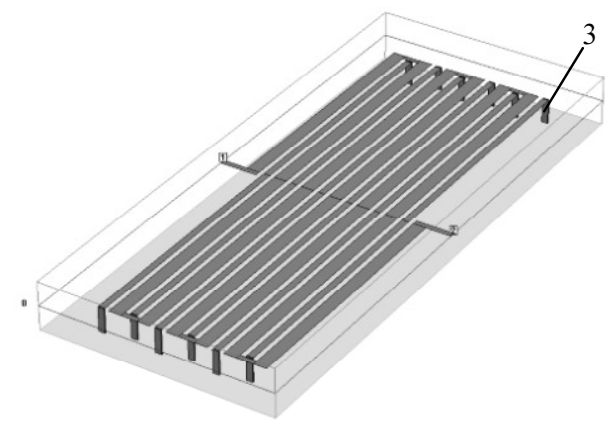

d)

2.3. pav. Meandrinių lètinimo sistemų trimačiai modeliai, kai papildomi ekranai įžeminti: a) - viename gale; b) - viduryje; c) - taške tarp ekrano galo ir jo vidurio; d) - iš abiejų galų; 1 - meandro formos laidininkas; 2 - papildomas ekranas; 3 - trumpiklis; 4 - oras; 5 - dielektrinis pagrindas; 6 - ižzemintas išorinis ekranas

Fig. 2.3. 3D models of meander slow-wave system with additional shields grounded at: a) - one edge; b) - center; c) - pint between the edge and a center; d) - both edges; 1 - meander-shape conductor; 2 - additional shield; 3 - grounded via; 4 - air; 5 - dielectric substrate; 6 - grounded external shield

Papildomi ekranai trumpikliais sujungiami su išoriniu ekranu, kuris kaip taisyklè yra įžeminamas. Keičiantis papildomo ekrano įžeminimo taškui, keičiasi ir nagrinejjamos lètinimo sistemos savybès. Tokiu būdu, siekiant pagerinti meandrinès lètinimo sistemos dispersines savybes ir padidinti praleidžiamų dažnių juostos ploti, sukuriami ir tiriami keturi meandrinių letinimo sistemų su papildomais ekranais kompiuteriniai modeliai, kurių topologijos pavaizduotos 2.2 paveiksle. Šiuo atveju meandro formos laidininko plotis yra žymimas $w_{1}$, papil- 
domo ekrano plotis $-w_{2}$, o laidininko jungiančio gretimas meandro juosteles plotis $-w_{3}$. Tarpo tarp laidininko juostelès ir papildomo ekrano plotis pažymètas $s_{1}$.

Sudarytieji meandrinių lètinimo sistemų su papildomais ekranais modeliai skiriasi trumpiklių, jungiančių papildomą ir išorinį ekranus, išdèstymo padètimi išilgai papildomo ekrano. Pirmame modelyje (2.2 pav., a) papildomas ekranas yra izžeminamas viename gale, toje vietoje kur nèra meandro juostelių sujungimo. Antrame modelyje (2.2 pav., b), trumpiklis yra išdèstomas papildomo ekrano viduryje. Trečią modeli (2.2 pav., c) sudaro meandrinè lètinimo sistema su papildomais ekranais, izžemintais taške tarp papildomo ekrano galo ir jo vidurio. Ketvirtas modelis (2.2 pav., d) sudaromas, įžeminus papildomus ekranus iš abiejų galų.

Meandrinių lètinimo sistemų su papildomais ekranais savybių tyrimui, taikant momentu metodą, Sonnet ${ }^{\circledR}$ specializuotu programų paketu sukurti trimačiai kompiuteriniai modeliai pavaizduoti 2.3 paveiksle. Kiekviena sistema yra stačiakampio formos, sudaryta iš 7 lygiagrečių, tarpusavyje sujungtų laidininkų, kurie sudaro meandro formos laidininką ir 6 papildomų ekranų, trumpikliais sujungtų su išoriniu ekranu. Meandro juostelès ir papildomi ekranai patalpinti ant dielektrinès plokštelès su santykine dielektrine skvarba $\varepsilon_{\mathrm{r}}$. Šios plokštelès apatinè dalis padengta metalo sluoksniu, kuris sudaro išorinį ekraną. Virš plokštelès yra oras. Taigi sistemos skerspjūvyje yra du dielektriko sluoksniai. Apatinis dielektrinis sluoksnis turi santykinę dielektrinę skvarbą $\varepsilon_{\mathrm{r}}=7,3$. Tai stiklo kerami$\mathrm{ka}$, naudojama mikrobangų integrinių grandynu gamyboje (Umayahara, Nishikawa 2003). Viršutini sluoksni sudaro oras kurio santykiné dielektrinė skvarba lygi 1. Sistemos iejjimas ir išejimas yra išdèstyti ties meandro laidininko juostelès viduriu. Meandrinès lètinimo sistemos matmenys: $2 A=19,6 \mathrm{~mm}, w_{1}=$ $0,5 \mathrm{~mm}, w_{2}=0,25 \mathrm{~mm}, w_{3}=0,2 \mathrm{~mm}, s_{1}=0,2 \mathrm{~mm}, h=0,5 \mathrm{~mm}$. Tyrimu metu visi laidininkai laikyti idealiai laidžiais. Taigi tirta sistema be nuostolių.

\subsubsection{Meandrinès lètinimo sistemos su modifikuotomis kraštụ topologijomis}

Meandrinès lètinimo sistemos ilgą laiką buvo tiriamos taikant daugialaidžių linijų metodą kuriame daroma prielaida, kad sudarant meandro formos laidininką, gretimos juostelès kraštuose yra sujungiamos be galo plonu laidininku (Gurskas et al. 2010). Tokia prielaida neleidžia ịvertinti kraštuose vykstančius procesus, ì kuriuos tikslinga atsižvelgti projektuojant lètinimo įtaisus. Procesus meandrinès lètinimo sistemos kraštuose imanoma ịvertinti taikant skaitiniais metodais grịstus modelius. 


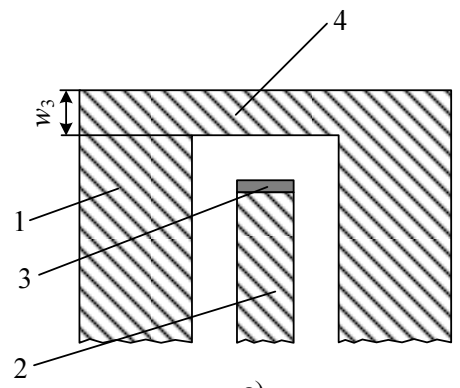

a)

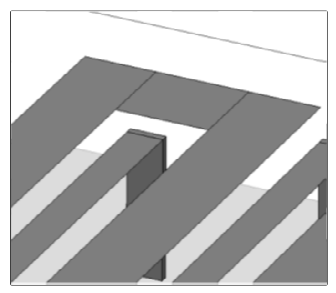

b)

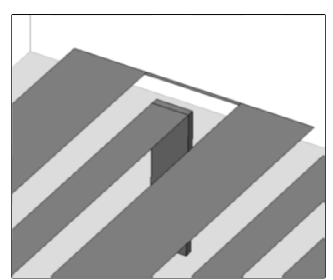

c)

2.4 pav. Laidininko, jungiančio gretimas meandro juosteles, pločio keitimas: a) - meandro krašto su juosteles jungiančiu laidininku topologija;

b) - didžiausias ir c) - mažiausias jungiančio laidininko plotis $w_{3}$; 1 - meandro juostelè; 2 - papildomas ekranas; 3 - sujungimo su išoriniu ekranu taškas; 4 - meandro juosteles jungiantis laidininkas

Fig. 2.4. Change of a width of a conductor connecting adjacent meander strips: a) - topology of the edge of a meander with a conductor connecting adjacent strips; b) - widest and c) - narrowest width $w_{3}$ of a connecting conductor; 3 - grounded via; 4 - conductor connecting adjacent meander strips

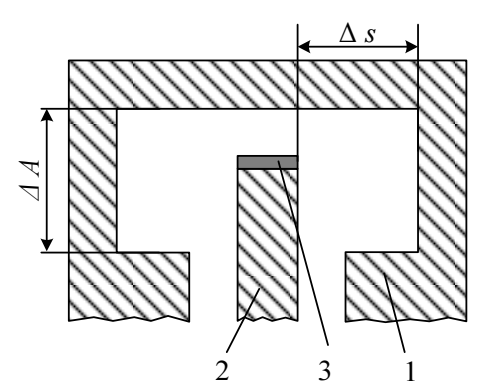

a)

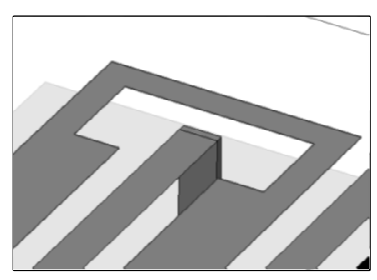

b)

2.5 pav. Meandrinès lètinimo sistemos su papildomais ekranais tarpu didinimo ties gretimų meandro laidininkų sujungimais tyrimas:

a) - topologija; b) - trimačio modelio fragmentas; 1 - meandro formos

laidininkas; 2 - papildomas ekranas; 3 - sujungimo su išoriniu ekranu taškas

Fig. 2.5. Investigation of gap increase of meander slow-wave system with additional shields in the area where meander strips form a loop:

a) - topology; b) - 3D view; 1 - meander shape conductor; 2 - additional shield; 3 - grounded via 


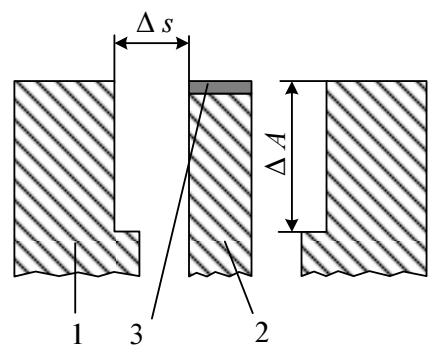

a)

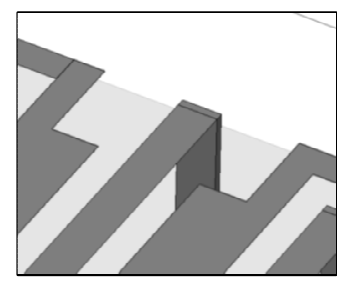

b)

2.6 pav. Meandrinès lètinimo sistemos su papildomais ekranais tarpų didinimo ties atvirais meandro laidininkais tyrimas: a) - topologija; b) - trimačio modelio fragmentas; 1 - meandro formos laidininkas;

2 - papildomas ekranas; 3 - sujungimo su išoriniu ekranu taškas

Fig. 2.6. Investigation of gap increase of meander slow-wave system with additional shields in the area where meander strips are open: a) - topology;

b) - 3D view; 1 - meander-shape conductor; 2 - additional shield;

3 - grounded via

Norint nustatyti meandro kraštų topologijos įtaką sistemos dispersinėms charakteristikoms, buvo sudarytos trys skirtingos meandrinès letinimo sistemos su papildomais ekranais įžemintais iš abieju galų (2.2 pav., d) topologijos. Pirmoji topologija pavaizduota 2.4 paveiksle, a. Siuo tyrimu siekiama nustatyti kaip keičiasi meandrinès lètinimo sistemos su papildomais ekranais dispersinès charakteristikos keičiant laidininko, jungiančio gretimas meandro juosteles, plotį $w_{3}$. 2.4 paveiksle taip pat parodyti trimačio modelio fragmentai iš kurių matyti du ištirti meandro juostelių sujungimo variantai: esant plačiam jungiančiam laidininkui (2.4 pav., b) ir esant siauram jungiančiam laidininkui (2.4 pav., c).

Antrojo ir trečiojo meandrinių lètinimo sistemų su papildomais ekranais tyrimų modelių topologijos yra pavaizduotos 2.5 ir 2.6 paveiksluose, a. Jos skirtos tarpų tarp meandro juostelių ir papildomų ekranų įtakos tyrimui. Iš paveikslų matyti, kad tyrimo metu $\Delta A$ ilgio meandro juostelès atkarpoje, esančioje viename ir kitame papildomo ekrano gale, buvo keičiamas tarpo $s_{1}$ plotis. Keičiamos dalies plotis buvo žymimas $\Delta s$ ir parenkamas didesnis už pradini plotị $s_{1}$. Tokiu būdu buvo didinamas tarpas papildomo ekrano įžeminimo taško ir meandrinės lètinimo sistemos laidininko aplinkoje. Taigi pirmuoju atveju (2.5 pav., a) tarpas buvo didinamas vietose, kur sujungiami gretimi meandro laidininkai, antruoju (2.6 pav., a) - vietose, kur meandro laidininkai atviri. Be to, paveiksluose pavaizduoti trimačio modelio fragmentai (2.5 ir 2.6 pav., b). 


\subsection{Meandrinių lètinimo sistemų su papildomais ekranais modelių tyrimo metodika}

Šiame poskyryje aprašomos meandrinių lètinimo sistemu su papildomais ekranais tyrimo metodikos. Pateikiamas modelių, sukurtų taikant specializuotą programų paketą Sonnet ${ }^{\circledR}$, dažninių charakteristikų apskaičiavimo algoritmas. Sistemos vèlinimo trukmè nustatoma iš sklaidos parametrų, gautu modeli analizuojant momentu metodu ir duomenis apdorojant MATLAB ${ }^{\circledR}$ paketu bei jam skirtu įrankiu SonnetLab Toolbox. Taip pat siūloma meandrinių lètinimo sistemų su papildomais ekranais iejjimo varžos nustatymo metodika, kuri reikalinga sistemos suderinimo su signalu traktu įvertinimui.

\subsubsection{Dažninių charakteristikų apskaičiavimo algoritmas}

Aukštadažnėms periodinėms sistemoms modeliuoti ir jų savybėms analizuoti tinka formalūs keturpolių ir daugiapolių naudojimu grịsti metodai (Štaras et al. 2010). Taikant šiuos metodus, sistemą modeliuojantys keturpoliai ir daugiapoliai dažniausiai apibūdinami apibendrintų $\underline{A} \underline{B} \underline{C} \underline{D}$ arba sklaidos $\underline{S}$ parametrų matricomis (Tascone et al. 2000).

Lètinimo sistemos signalų trakto grandinès schema, modeliuojama keturpoliu, pavaizduota 2.7 paveiksle, a. Schemoje $\underline{U}_{1}$ ir $\underline{I}_{1}$ žymi įtampos keturpolio įèjime ir ị keturpoli įtekančios srovès kompleksines amplitudes, $\underline{U}_{2}$ ir $\underline{I}_{2}-$ itampos keturpolio išèjime ir iš jo ištekančios srovès kompleksines amplitudes, $\underline{E}-$ signalų šaltinio kompleksinę elektrovarą, $\underline{Z}_{\mathrm{i}}$ - signalų šaltinio kompleksinę vidinę varžą, $\underline{Z}_{\mathrm{a}}$ - lètinimo sistemos kompleksinę apkrovos varžą.

$\underline{A} \underline{B} \underline{C} \underline{D}$ parametrai skirti taikyti sutelktuju parametru grandinèms, todèl pagal juos negalima įvertinti grandinèje vykstančių banginių procesų. Norint lètinimo sistemos modelyje ivertinti banginius procesus, reikia keturpoliui taikyti sklaidos parametrus (2.7 pav., b). Modeliuojant letinimo sistemą $\underline{S}$ parametrais, iejjimo ir išẻjimo įtampos bei srovès išskaidomos i sklaidos kompleksinius komponentus $\underline{a}_{i}, \underline{b}_{i}$, kurie proporcingi krintančių $i$ keturpolio polius ir atsispindejjusių nuo jų bangu įtampoms ir srovėms:

$$
\begin{gathered}
\underline{U}_{i}=\underline{U}_{\mathrm{K} i}+\underline{U}_{\mathrm{A} i}=\sqrt{\underline{Z}_{0 i}}\left(\underline{a}_{i}+\underline{b}_{i}\right), \\
\underline{I}_{i}=\frac{1}{\underline{Z}_{0 i}}\left(\underline{U}_{\mathrm{K} i}-\underline{U}_{\mathrm{A} i}\right)=\frac{1}{\sqrt{\underline{Z}_{0 i}}}\left(\underline{a}_{i}-\underline{b}_{i}\right),
\end{gathered}
$$

čia $\underline{U}_{i}, \underline{I}_{i}$ - keturpolio $i$-ojo poliaus bangos ịtampos ir srovès kompleksinès amplitudès, $\underline{U}_{\mathrm{K} i}, \underline{U}_{\mathrm{A} i}-\mathrm{i}$ keturpolio $i$-aji polių krintančios ir nuo jo atsispindejjusios 
bangu ịtampos kompleksinès amplitudès, $\underline{a}_{i}, \underline{b}_{i}-\mathrm{i}$ keturpolio $i$-ajji polių krintančio ir nuo jo atspindèjusio sklaidos komponento kompleksinès amplitudès, $\underline{Z}_{0 i}-$ keturpolio $i$-ojo poliaus banginè varža, $i=1,2$ - keturpolio iejjimo ir išejjimo polių porų eilès numeris.

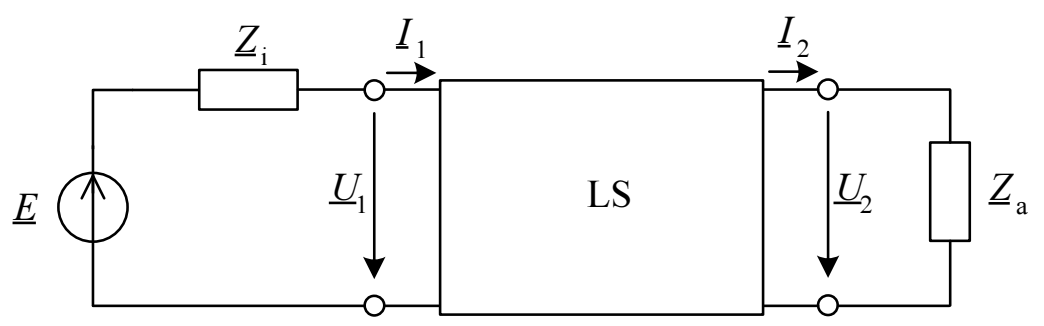

a)

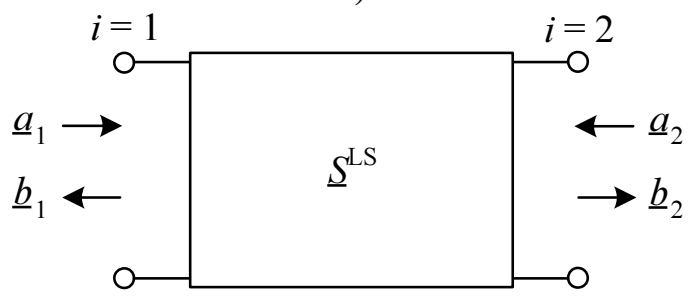

b)

2.7 pav. Lètinimo sistemos: a) signalų trakto schema; b) modeliavimui naudojamas keturpolis, apibūdinamas sklaidos parametrais $\underline{S}^{\mathrm{LS}}$ (ک̌taras et al. 2010)

Fig. 2.7. Slow-wave system: a) the model of the signal path; b) two-port circuit with $\underline{S}$ parameters used for modeling (Staras et al. 2010)

Iš (2.1) ir (2.2) lygčių išplaukia, kad sklaidos komponentai nusako bangų itampas arba sroves. Jie apskaičiuojami taip:

$$
\begin{gathered}
\underline{a}_{i}=\frac{\underline{U}_{\mathrm{K} i}}{\sqrt{\underline{Z}_{0 i}}}=\underline{I}_{\mathrm{K} i} \sqrt{\underline{Z}_{0 i}}=\frac{1}{2}\left(\frac{\underline{U}_{i}}{\sqrt{\underline{Z}_{0 i}}}+\underline{I}_{i} \sqrt{\underline{Z}_{0 i}}\right), \\
\underline{b}_{i}=\frac{\underline{U}_{\mathrm{A} i}}{\sqrt{\underline{Z}_{0 i}}}=\underline{I}_{\mathrm{A} i} \sqrt{\underline{Z}_{0 i}}=\frac{1}{2}\left(\frac{\underline{U}_{i}}{\sqrt{\underline{Z}_{0 i}}}-\underline{I}_{i} \sqrt{\underline{Z}_{0 i}}\right) .
\end{gathered}
$$


Atsispindejusius $\underline{b}_{1}, \underline{b}_{2}$ ir krintančius $\underline{a}_{1}, \underline{a}_{2}$ sklaidos komponentus keturpolio iejjime ir išejjime tarpusavyje sieja sklaidos parametrai $\underline{S}^{\mathrm{LS}}$ :

$$
\begin{aligned}
& \underline{b}_{1}=\underline{S}_{11}^{\mathrm{LS}} \underline{a}_{1}+\underline{S}_{12}^{\mathrm{LS}} \underline{a}_{2}, \\
& \underline{b}_{2}=\underline{S}_{21}^{\mathrm{LS}} \underline{a}_{1}+\underline{S}_{22}^{\mathrm{LS}} \underline{a}_{2},
\end{aligned}
$$

čia $\underline{S}_{11}^{\mathrm{LS}}, \underline{S}_{12}^{\mathrm{LS}}, \underline{S}_{21}^{\mathrm{LS}}, \underline{S}_{22}^{\mathrm{LS}}$ - keturpolio sklaidos arba $\underline{S}^{\mathrm{LS}}$ parametrai. Taigi apibūdinus lètinimo sistemą sklaidos parametrais, visuomet galima ịvertinti šioje sistemoje vykstančius banginius procesus ir apskaičiuoti jos svarbiausias dažnines charakteristikas.

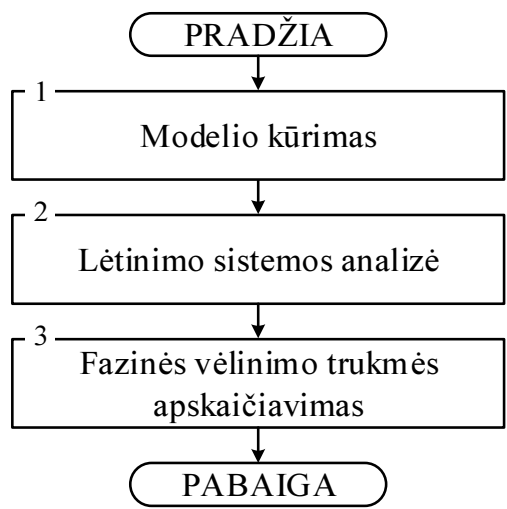

2.8 pav. Meandrinès lètinimo sistemos su papildomais ekranais fazinès vèlinimo trukmès apskaičiavimo algoritmas

Fig. 2.8. The calculation algorithm of the phase delay time of meander slow-wave system with additional shields

Meandrinès lètinimo sistemos su papildomais ekranais fazinès vèlinimo trukmès priklausomybę nuo dažnio galime rasti taikant 2.8 paveiksle pateiktą skaičiavimo algoritmą. Visų pirmą, taikant programų paketo Sonnet ${ }^{\circledR}$ grafinę aplinką, nubraižomas analizuojamos sistemos modelio eskizas ir nustatomi pagrindiniai parametrai: analizuojamos srities dydis, tinklelio tankis, dažnių ruožas, kuriame bus apskaičiuoti sistemos sklaidos parametrai. Taip pat apibrežziamos laidininko ir dielektrinio pagrindo savybès (1 blokas). Toliau, taikant momentų metodą, atliekama lètinimo sistemos analizè (2 blokas), kurios rezultatas yra apskaičiuotieji sklaidos parametrai. Gauti rezultatai išsaugomi tekstiniame faile, Touchstone ${ }^{\circledR}$ formatu. Šio formato, sukurto kompanijos Agilent Technologies, failai naudojami îvairiems daugiapolių parametrams saugoti. Tolimesni skaičiavimai vykdomi MATLAB $^{\circledR}$ terpeje, įrankiu SonnetLab 
Toolbox (3 blokas). Jame esančios funkcijos leidžia iš Touchstone ${ }^{\circledR}$ formatu išsaugoto failo išskirti reikiama sklaidos parametrą. Mūsų atveju, sistemos fazinè vèlinimo trukmè buvo nustatoma iš $\underline{S}_{21}^{\mathrm{LS}}$ parametro, kuris turi keturpolio perdavimo funkcijos fizikinę prasmę, taikant išraišką:

$$
t_{\mathrm{v}}=\frac{\theta_{\underline{S}_{21}^{\mathrm{LS}}}}{2 \pi \cdot f},
$$

čia $\theta_{\underline{S}_{21}^{\mathrm{LS}}}$ - fazès skirtumo kampas, apskaičiuojamas iš sklaidos parametro $\underline{S}_{21}^{\mathrm{LS}}(f)=e^{-j \theta_{S 21}}$, radianais; $f$ - dažnis, kuriame apskaičiuotas $\underline{S}_{21}^{\mathrm{LS}}(f)$ parametras, hercais.

\subsection{2. lèjimo varžos nustatymo metodika}

Dažnai lètinimo sistemų suderinimo su signalų traktais nustatymui naudojama ne lètinimo sistemos banginè varža, o jos iejjimo varža (Štaras et al. 2010). Modeliuojamų lètinimo sistemų iejjimo varža ties $n$-tuoju laidininku apskaičiuojama, kaip tai ịprasta keturpoliuose, pagal ịtampos $\underline{U}_{n}(x)$ ir srovès $\underline{I}_{n}(x)$ kompleksinių amplitudžių šiame laidininke santykị:

$$
\underline{Z}_{\mathrm{IN} n}=\frac{\underline{U}_{n}(x)}{\underline{I}_{n}(x)} .
$$

Literatūroje nèra duomenų apie meandrinių lètinimo sistemų su papildomais ekranais iejjimo varžos ir jos sklaidos parametrų dažnines charakteristikas, todèl šiame skyrelyje pateikiama tokių lètinimo sistemu iejjimo varžos nustatymo, taikant momentų metodu grịstą specializuotą programų paketą Sonnet ${ }^{\circledR}$, metodika.

İejimo varžos dažninių charakteristikų tyrimui sukurtas meandrinès lètinimo sistemos su papildomais ekranais modelis, pavaizduotas 2.9 paveiksle. Jis nedaug skiriasi nuo modelių, pateiktų 2.3 paveiksle. Siekiant išmatuoti iejjimo varžą sistemos kraštuose, šoniniai meandro laidininkai buvo pailginti dydžiu $A$. Be to, prie pailgintų meandro laidininkų atsirado papildomi ekranai. Tokiu būdu, naują sistemą sudaro ne 6 , o 8 papildomi ekranai.

Meandrinių lètinimo sistemų su papildomais ekranais įejjimo varža buvo nustatoma pagal darbe (Skudutis, Daškevičius 2002) aprašomą spiralinių lètinimo sistemų dažninių charakteristikų skaičiavimo metodiką. Iejjimo varža žemuosiuose dažniuose buvo apskaičiuojama dviejose vietose: sistemos kraštuose, kurie 2.9 paveiksle žymimi skaičiais 1 ir 2 ir viduryje, kuris pažymètas skaičiumi 3. 
2.10 paveiksle pavaizduota įèjimo varžos žemuosiuose dažniuose nustatymo sistemos kraštuose principinè schema. Iš schemos analizès išplaukia, kad grandineje nebus atspindžių, jeigu apkrovos ir generatoriaus varžos $\underline{Z}_{\mathrm{g}}$ ir $\underline{Z}_{\mathrm{a}}$ yra suderintos su sistemos iejjimo varža žemuosiuose dažniuose. Tokiu būdu, pasirinkus žemaji dažni $f$, sistemos iejjimo varžą galima rasti keičiant apkrovos ir generatoriaus varžas tol, kol gaunama mažiausia sklaidos parametro $\underline{S}_{11}^{\mathrm{LS}}$ vertè.

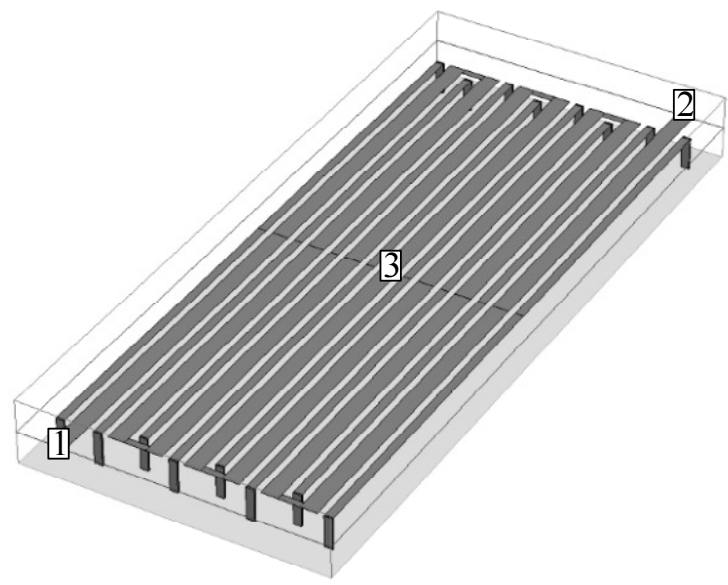

2.9 pav. Meandrinès lètinimo sistemos su papildomais ekranais modelis su iejjimo varžos nustatymo taškais

Fig. 2.9. Ports at which input impedance of a meander slow-wave system with additional shield was measured

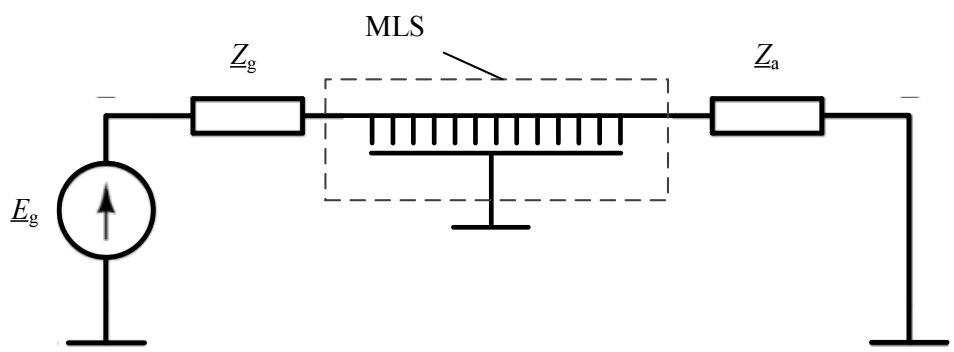

2.10 pav. İejjimo varžos žemuosiuose dažniuose nustatymo meandrinès lètinimo sistemos su papildomais ekranais kraštuose principinè schema

Fig. 2.10. A signal path developed for determination of the input impedance on the edge of a meander slow-wave system with additional shields 
Kadangi $\underline{S}_{11}^{\mathrm{LS}}$ parametras yra lètinimo sistemos atspindžio koeficientas, tai esant apkrovos, generatoriaus ir lètinimo sistemos varžų suderinamumui gaunami mažiausi atspindžiai. Tokiu būdų nustatoma iẹjimo varža lètinimo sistemos kraštuose žemuosiuose dažniuose $\underline{Z}_{\mathrm{IN}}(f)$.

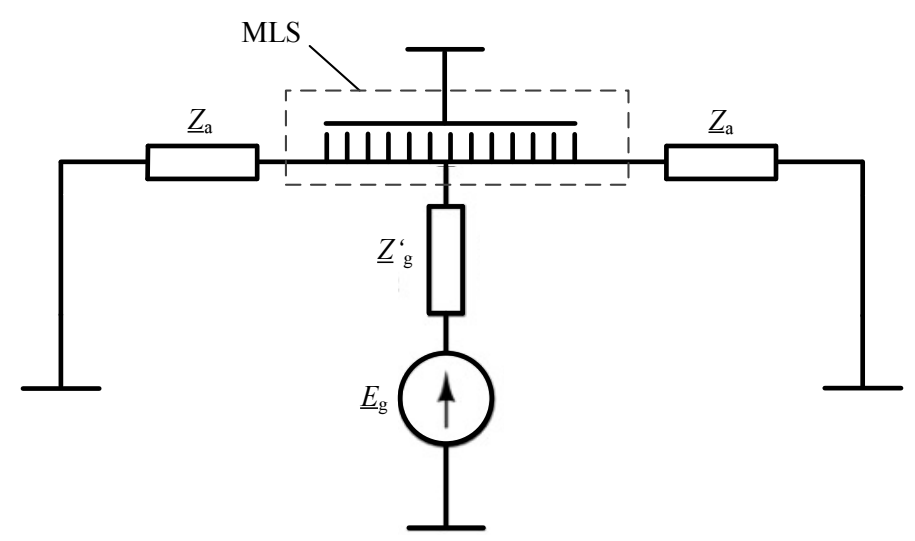

2.11 pav. İėjimo varžos žemuosiuose dažniuose nustatymo meandrinès lètinimo sistemos su papildomais ekranais viduryje principinè schema

Fig. 2.11. A signal path developed for determination of the input impedance in the center of a meander slow-wave system with additional shields

Nustatant ièjimo varžą meandrinès lètinimo sistemos su papildomais ekranais viduryje, naudojama grandinè, kurios principinè schema pavaizduota 2.11 paveiksle. Siuo atveju signalas yra siunčiamas i sistemos vidurị, o sistemos galai yra apkraunami varžomis, lygiomis sistemos iejjimo varžai žemujų dažnių srityje. Kadangi signalas siunčiamas lygiagrečiai ị dvi lètinimo sistemos puses, signalo šaltinio varža suderinimo etape turi būti du kartus mažesnè už sistemos ièjimo varžą žemuosiuose dažniuose. Taigi ji turi būti lygi pusei apkrovos varžos $\underline{Z}_{\mathrm{g}}{ }_{\mathrm{g}}=\underline{Z}_{\mathrm{a}} / 2$.

Sudarant modeli su Sonnet ${ }^{\circledR}$ programų paketu, lètinimo sistemos iejjimo ir išejjimo prievaduose prijungiami signalu šaltiniai ir apkrovos varžos, kurių apibendrinta principinè schema parodyta 2.12 paveiksle. Ją apibūdina keturi parametrai: aktyvioji varža $R$, reaktyvioji varža $X$, induktyvumas $L$ ir talpa $C$. Šių parametrų dydžius galima keisti. Tam Sonnet ${ }^{\mathbb{B}}$ programų pakete naudojama generatoriaus ir apkrovos varžų nustatymo 2.1 lentelè. Tyrimo metu buvo keičiama 
tik aktyvioji varža. Taigi $\underline{Z}_{\mathrm{g}}=R_{\mathrm{g}}, \underline{Z}_{\mathrm{a}}=R_{\mathrm{a}}$, o $R_{\mathrm{g}}=R_{\mathrm{a}}=Z_{\check{Z} \mathrm{D}}$. Gautoji $Z_{\check{Z} \mathrm{D}}$ vertè yra meandrinès lètinimo sistemos su papildomais ekranais įejjimo varža žemuosiuose dažniuose.

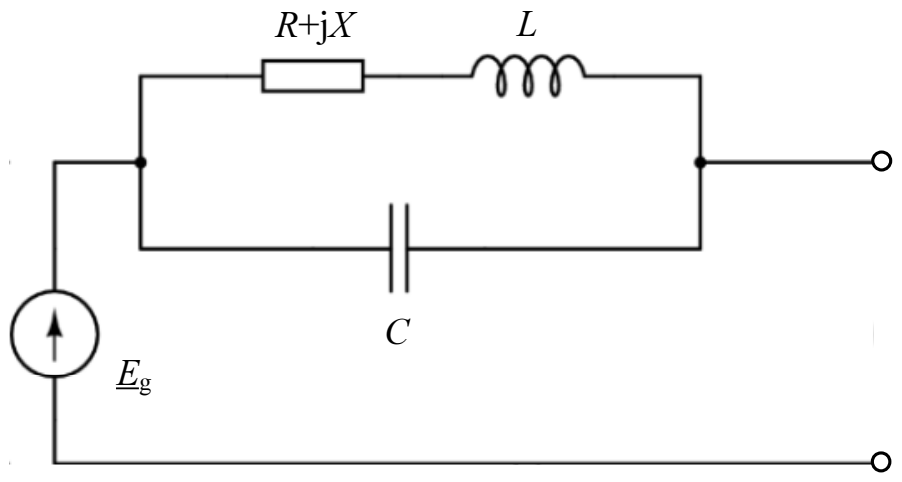

2.12 pav. Lètinimo sistemos ịejjimo ir išèjimo prievaduose prijungtų signalų šaltinių ir apkrovos varžų apibendrinta principinè schema

Fig. 2.12. Equivalent circuit of a signal generator and load resistances connected to a port of the slow-wave system

2.1 lentelè. Sonnet ${ }^{\circledR}$ programų paketo generatoriaus ir apkrovos varžų nustatymo lentelè Table 2.1. Settings for source and load resistances in Sonnet ${ }^{\mathbb{B}}$

\begin{tabular}{|c|c|c|c|c|}
\hline $\begin{array}{c}\text { Prievado nu- } \\
\text { meris }\end{array}$ & $\begin{array}{c}\text { Aktyvioji } \\
\text { varža, } \Omega\end{array}$ & $\begin{array}{c}\text { Reaktyvioji } \\
\text { varža, } \Omega\end{array}$ & Induktyvumas, $\mathrm{nH}$ & Talpa, $\mathrm{pF}$ \\
\hline 1 & 50 & 0 & 0 & 0 \\
\hline 2 & 50 & 0 & 0 & 0 \\
\hline 3 & 25 & 0 & 0 & 0 \\
\hline
\end{tabular}

İejimo varža žemuosiuose dažniuose buvo nustatoma iš $\underline{S}_{11}^{\mathrm{LS}}$ parametro. Atlikus sistemos analizę momentu metodu ir nustačius $\underline{S}_{11}^{\mathrm{LS}}$ parametro vertes, iejjimo varža gali būti apskaičiuota pagal išraišką:

$$
\underline{Z}_{\mathrm{IN}}=Z_{\mathrm{a}}\left(\frac{1+\underline{S}_{11}^{\mathrm{LS}}}{1-\underline{S}_{11}^{\mathrm{LS}}}\right),
$$

čia $Z_{\mathrm{a}}$ yra suderintoji apkrovos varžos vertè. Bendruoju atveju ièjimo varža $\underline{Z}_{\mathrm{IN}}$ yra kompleksinè ir lygi: 


$$
\underline{Z}_{\mathrm{IN}}=R_{\mathrm{IN}}+\mathrm{j} X_{\mathrm{IN}}
$$

Taigi iš kompleksinès įjjimo varžos vertès galima nustatyti aktyviąją

$$
R_{\mathrm{IN}}=\operatorname{Re}\left[\underline{Z}_{\mathrm{IN}}\right]
$$

ir reaktyviają

$$
X_{\mathrm{IN}}=\operatorname{Im}\left[\underline{Z}_{\mathrm{IN}}\right],
$$

iejjimo varžos dalis.

\subsection{Elektrinio lauko meandrinèse lètinimo sistemose trimačio pasiskirstymo modeliavimo metodika}

Taikant momentų metodą sukurtos metodikos krūvio pasiskirstymui meandrinių lètinimo sistemų dvimačiuose modeliuose (skersiniame jų pjūvyje) rasti. Šiame poskyryje siūloma metodika, kuri leidžia apskaičiuoti krūvio pasiskirstymą meandrinèse struktūrose trimatejje erdveje.

\subsubsection{Momentų metodo taikymas}

Didžioji dalis elektromagnetinių uždavinių gali būti išreikšta nehomogenine lygtimi (Sadiku 2001)

$$
L \Phi=g
$$

čia $L$ yra operatorius, kuris gali būti diferencialinis, integralinis arba integralinisdiferencialinis, $g$ - žinoma sužadinimo funkcija, kurios reikšmè šiame darbe lygi ị laidininką siunčiamam potencialui, o $\Phi$ - nežinoma funkcija, kurią reikia nustatyti. Šiame skyrelyje darysime prielaidą, jog $L$ yra integralinis arba integralinis-diferencialinis operatorius.

Sprendžiat elektromagnetinius uždavinius, sprendiniai dažnai yra ieškomi integralinių lygčių forma. (2.13) lygtị vadinsime integraline, jei joje esanti nežinoma funkcija $\Phi$ bus po integralo ženklu. Paprasčiausiais tokių lygčių pavyzdžiais galima laikyti Furjè ir Laplaso transformacijas. Integralinių lygčių sprendimui taikomas momentų metodas, kurị elektromagnetizmo uždaviniams spręsti pritaikè Haringtonas (Harrington 1967; Harrington 1968).

Siekdami paprasčiau atskleisti skaičiavimų momentų metodu algoritmą, panagrinėkime vienalytę perdavimo liniją laisvoje erdvèje. Jos skerspjūvis, pavaizduotas 2.13 paveiksle, gali būti analizuojamas kaip dvimatis uždavinys. Sakyki- 
me, kad laidininkų plotis $w$, atstumas tarp jų $2 h$. Viršutinio laidininko potencialas yra 1 voltas, apatinio - minus 1 voltas.

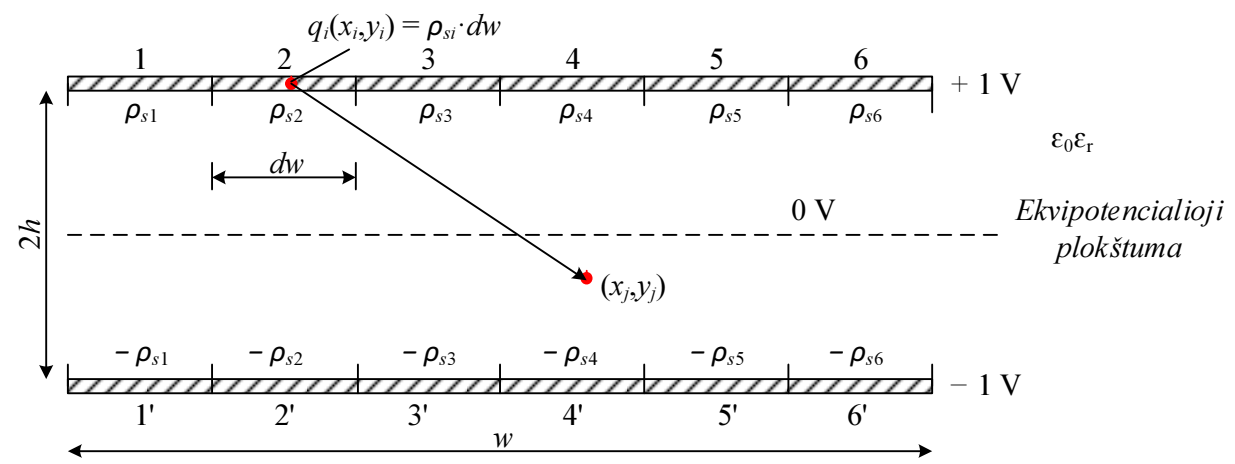

2.13 pav. Vienalytès perdavimo linijos skerspjūvis

Fig. 2.13. Cross-section of a homogeneous transmission line

Elektrinio lauko, atsiradusio dèl vienetinio krūvio $q_{i}$, esančio $P_{i}\left(x_{i}, y_{i}\right)$ taške, potencialas $\varphi_{j}$, esantis kitame $P_{j}\left(x_{j}, y_{j}\right)$ taške, gali būti nustatytas iš išraiškos:

$$
\varphi\left(x_{j}, y_{j}\right)=-\int_{L} \vec{E} d \vec{l} .
$$

Dvimatejje koordinačių sistemoje laisvoje erdvejje

$$
\vec{E}=\frac{q_{i}}{2 \pi \varepsilon_{0} r} \vec{r}^{0} .
$$

Nagrinejjamu atveju, integravimo kelio ir jègos linijos kryptys sutampa, todèl $\vec{r}^{0} \cdot d \vec{l}=d r$ ir galime užrašyti

$$
\varphi\left(x_{j}, y_{j}\right)=-\frac{q_{i}}{2 \pi \varepsilon_{o}} \int_{L} \frac{d r}{r}=-\frac{q_{i}}{2 \pi \varepsilon_{0}} \ln r,
$$

čia $r$ - atstumas nuo taškinio krūvio iki stebejjimo taško. Stačiakampejje koordinačių sistemoje

$$
r=\sqrt{\left(x_{i}-x_{j}\right)^{2}+\left(y_{i}-y_{j}\right)^{2}},
$$

todèl 


$$
\varphi\left(x_{j}, y_{j}\right)=-\frac{q_{i}}{2 \pi \varepsilon_{0}} \ln \sqrt{\left(x_{i}-x_{j}\right)^{2}+\left(y_{i}-y_{j}\right)^{2}} .
$$

Pagal priimtą sąlygą krūvis $q_{i}$ yra vienetinis ir randasi ties plona laidžia styga (kitų laidininkų nèra), todèl (2.18) išraišką galima užrašyti kitaip:

$$
G\left(P_{j}, P_{i}\right)=-\frac{1}{2 \pi \varepsilon_{0}} \ln \sqrt{\left(x_{i}-x_{j}\right)^{2}+\left(y_{i}-y_{j}\right)^{2}} .
$$

Ši funkcija yra žinoma kaip tam tikros srities Gryno funkcija. Jeigu nagrinèjama terpé yra nevienalytė ir susideda iš įvairių dielektrikų, turèsime îvairias Gryno funkcijas, priklausančias nuo krūvio ir stebėjimo taško tarpusavio padèties. Potencialų, atsirandančių dèl atskirų krūvių, kurių krūvio tankis $\rho\left(P_{i}\right)$ laidininke kinta, superpozicija išreiškiama integraline lygtimi (Fooks, Zakarevicius 1990)

$$
\varphi\left(x_{j}, y_{j}\right)=\int G\left(P_{j}, P_{i}\right) \rho\left(P_{i}\right) d P_{i} .
$$

Lygtys, sudarytos laidininkų potencialams, yra naudingos, nes jos yra taikomos skaičiuojant elektrines talpas. Tokiu būdu, jeigu laidininkas padalintas ị dalines sritis, (2.20) lygti galima užrašyti kiekvienos srities geometriniam centrui ir gauti matricinę lygti:

$$
[\varphi]=[\mathbf{A}] \times[\mathbf{q}],
$$

čia $[\boldsymbol{\varphi}]$ - potencialų taškuose $\left(x_{i}, y_{i}\right)$ vektorius-stulpelis, $[\mathbf{q}]$ - krūvių taškuose $\left(x_{j}, y_{j}\right)$ matrica-stulpelis, [A] - koeficientų matrica. Invertuojant (2.21) lygtį, gauname

$$
[\mathbf{q}]=[\mathbf{A}]^{-1} \times[\varphi],
$$

ir galime nustatyti bendrą krūvị arba krūvio pasiskirstymą nagrinèjamame laidininke, o sumuojant visų dalinių sričių krūvius, ir talpą ilgio vienetui.

\subsubsection{Siūloma metodika}

Nagrinèkime meandrinès lètinimo sistemos stačiakampę atkarpą, kuri pavaizduota 2.14 paveiksle. Atkarpa yra padalinta ị 6 dalines sritis, vienos matmenys yra $a \times a$, todèl bendras atkarpos ilgis $L=2 a$, o plotis $W=3 a$. Nulinio potencialo plokštuma sukuriama, išdèsčius to paties dydžio ir priešingo ženklo krūvị atstumu $2 h$ nuo tikrojo krūvio. Taip pat reikètų pažymèti, $\operatorname{kad} h=a$.

Matematinis meandrinès lètinimo sistemos stačiakampès atkarpos modelis bus sudarytas iš tiesinių lygčių sistemos, kuri aprašo potencialų priklausomybę 
nuo krūvio tankių $\rho_{i j}$. Pritaikant momentų metodą ir dalinių atvaizdų principą (Urbanavičius, Martavičius 2006) bei atliekant tris žingsnius, galime rasti kiekvieno krūvio įtaką potencialui tam tikrame taške:

1. Rasti savaimini potencialą taške $P_{i i}$, kuris atsiranda dèl krūvio $q_{i i}$ ir jo pirmo dalinio atvaizdo esančių tame pačiame taške. Irodoma, kad tolygiai ịkrautos $a \times a$ kvadratinès plokštelès centre potencialas bus lygus

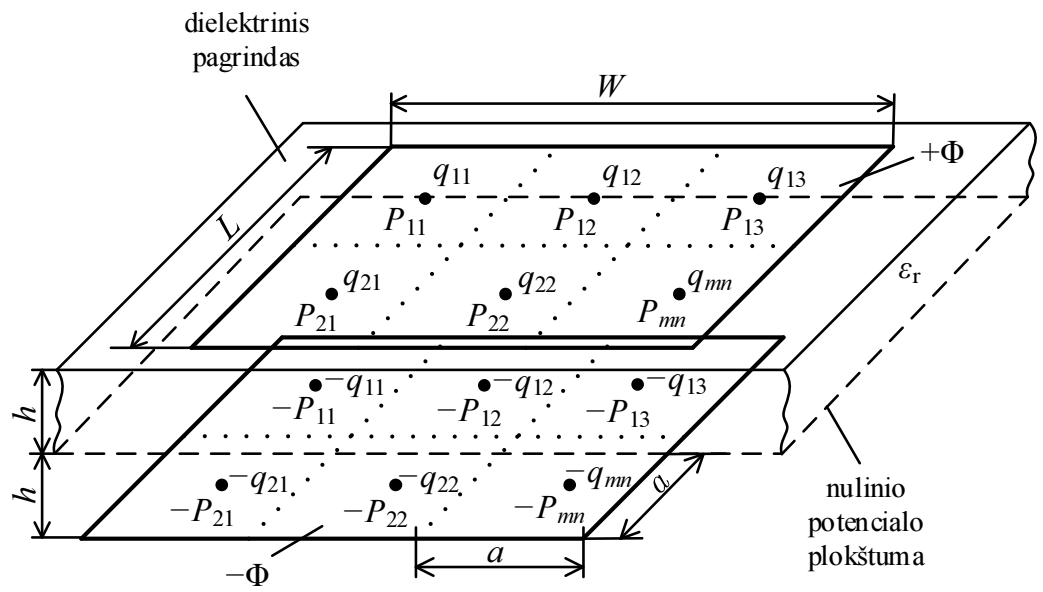

2.14 pav. Meandrinès lètinimo sistemos stačiakampẻ atkarpa

Fig. 2.14. Rectangular section of meander slow-wave system

$$
\varphi_{0,0}=\frac{a \rho_{S 0}}{\pi \varepsilon} \ln (1+\sqrt{2}),
$$

todèl šiuo atveju

$$
\varphi_{\mathrm{a}}\left(P_{i i}: P_{i i}\right)=\frac{a(1+K) q_{i i}}{\pi \varepsilon_{0}} \ln (1+\sqrt{2}),
$$

čia $K$ - atspindžio koeficientas, kuris priklauso nuo terpių dielektrinès skvarbos:

$$
K=-\frac{\varepsilon_{\mathrm{r}}-1}{\varepsilon_{\mathrm{r}}+1} .
$$

2. Rasti potencialą, kuris atsiranda dèl kitų krūvio $q_{i i}$ dalinių atvaizdų: 


$$
\varphi_{\mathrm{b}}\left(P_{i i}: P_{i i}\right)=-\frac{a^{2} K\left(1-K^{2}\right) q_{i i}}{4 \pi \varepsilon_{0}} \sum_{n=1}^{\infty} K^{2(n-1)} \frac{1}{2 n h},
$$

čia $n$ - dalinių atvaizdų kiekis.

3. Rasti potencialą, kuris atsiranda dèl veidrodinio krūvio $-q_{i i}$ ir visų jo dalinių atvaizdų, kurie yra taške $-P_{i i}$ :

$$
\varphi\left(P_{i i}:-P_{i i}\right)=-\frac{a^{2}\left(1-K^{2}\right) q_{i i}}{4 \pi \varepsilon_{0}} \sum_{n=1}^{\infty} K^{2(n-1)} \frac{1}{(2 n-1) h} .
$$

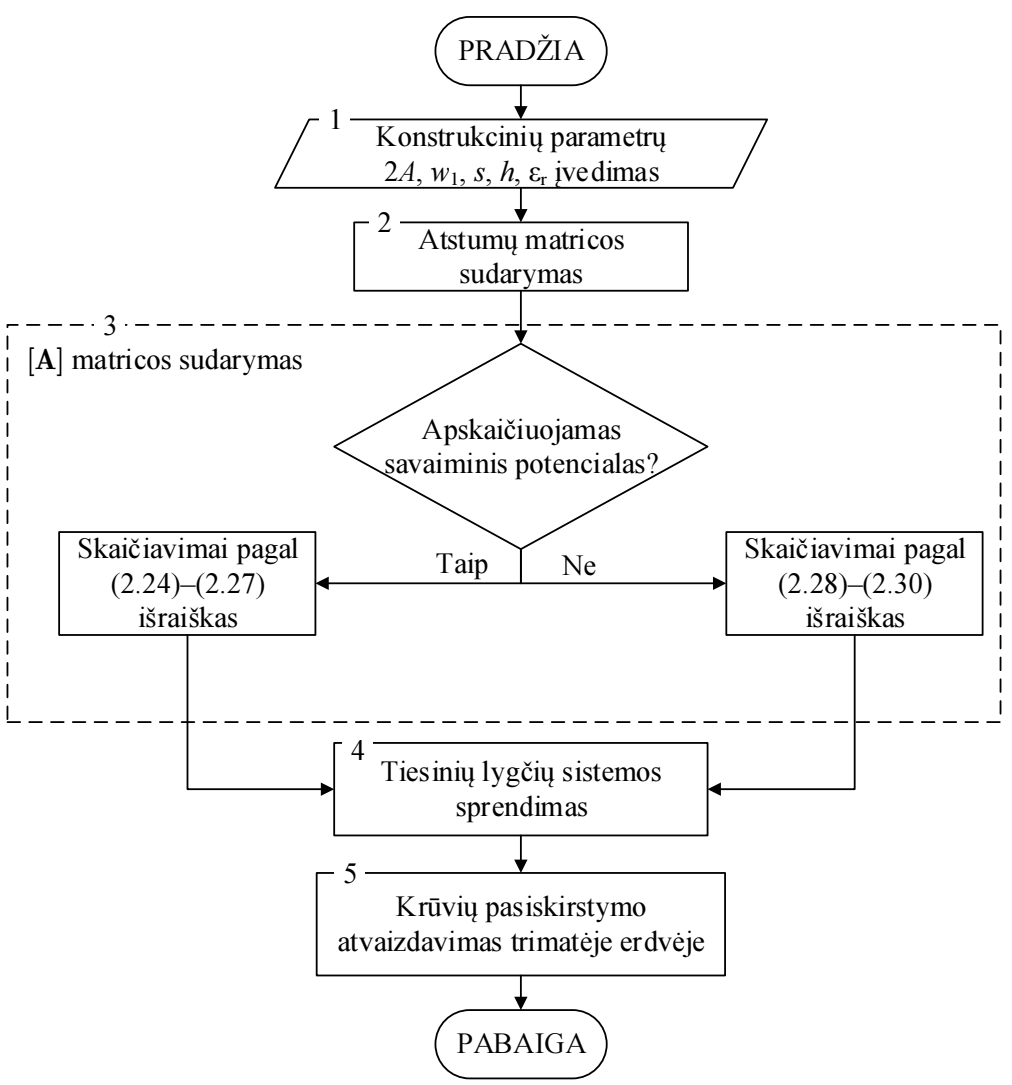

2.15 pav. Elektrinio lauko meandrinèse lètinimo sistemose trimačio pasiskirstymo modeliavimo algoritmas

Fig. 2.15. Algorithm for modeling of three-dimensional electric field distribution of meander slow-wave system 
Potencialo taške $P_{i j}$, kuris atsiranda dèl krūvio $q_{m n}$, esančio taške $P_{m n}$, nustatymui pakeičiamos 1-3 žingsnio išraiškos. Tuomet (2.24) išraiška atrodys taip:

$$
\varphi_{\mathrm{a}}\left(P_{i j}: P_{m n}\right)=\frac{a^{2}(1+K) q_{m n}}{4 \pi \varepsilon_{0}} \frac{1}{l},
$$

čia $l$ yra atstumas tarp tašku $P_{i j}$ ir $P_{m n}$, apskaičiuojamas pagal formulę $l=\sqrt{(i-m)^{2}+(j-n)^{2}}$.

Antrojo žingsnio (2.26) išraiška pasikeičia ị:

$$
\varphi_{\mathrm{b}}\left(P_{i j}: P_{m n}\right)=-\frac{a^{2} K\left(1-K^{2}\right) q_{m n}}{4 \pi \varepsilon_{0}} \sum_{n=1}^{\infty} K^{2(n-1)} \frac{1}{\sqrt{l^{2}+(2 n h)^{2}}} .
$$

Trečiame žingsnyje esanti išraiška pasikeičia į:

$$
\varphi\left(P_{i j}:-P_{m n}\right)=-\frac{a^{2}\left(1-K^{2}\right) q_{m n}}{4 \pi \varepsilon_{0}} \sum_{n=1}^{\infty} K^{2(n-1)} \frac{1}{\sqrt{l^{2}+[(2 n-1) h]^{2}}} .
$$

Atlikę skaičiavimus aukščiau parodytu būdu, pagal (2.21) galèsime sudaryti matricinę lygti, o nežinomus krūvius rasti taikant (2.22) išraišką.

Elektrinio lauko meandrinèse lètinimo sistemose trimačio pasiskirstymo modelio algoritmas yra pateiktas 2.15 paveiksle. Pagal ši algoritmą, pirmuoju žingsniu įvedami pradiniai konstrukciniai parametrai: meandro laidininko ilgis $2 A$ ir plotis $w_{1}$, tarpo tarp laidininku plotis $s$, pagrindo dielektrinè skvarba $\varepsilon_{\mathrm{r}}$ bei storis $h$. Antrame žingsnyje sistema yra dalinama ị stačiakampes dalis bei sudaroma atstumų matrica, kurioje saugoma informacija apie stačiakampių dalių tarpusavio išdèstymą. Trečiame žingsnyje, pagal (2.24)-(2.30) sudaroma [A] matrica. Matricos $[\mathbf{A}]$ elementas $\mathbf{A}_{i j}$ apibūdina $i$-osios dalinès srities potencialą, kuris atsiranda dèl $j$-oje dalinèje srityje esančio krūvio. Ketvirtame žingsnyje nežinomi krūviai randami pagal (2.22) išraišką sprendžiant tiesinių lygčių sistemą. Penktame žingsnyje krūvių pasiskirstymas atvaizduojamas trimatejje erdvéje.

\subsection{Antrojo skyriaus išvados}

Remiantis sudarytais meandrinių lètinimo sistemų kompiuteriniais modeliais ir pasiūlytomis jų tyrimo metodikomis galima daryti šias išvadas: 
1. Meandrinèse lètinimo sistemose su papildomais ekranais vykstančius procesus galima ištirti naudojantis sukurtais jų modeliais, kurie skiriasi trumpiklių, jungiančių papildomą ir išorinį ekranus, išdèstymo padètimi išilgai papildomo ekrano. Tyrimams geriausiai tinka meandrinių lètinimo sistemų modeliai, kurių papildomi ekranai įžeminami: viename gale, iš abiejų galų, viduryje ir taške tarp papildomo ekrano galo ir vidurio.

2. Projektuojant meandrines lètinimo sistemas su papildomais ekranais tikslinga atsižvelgti ị kraštuose, kurių topologija gali turèti didelę įtaką sistemos savybèms, vykstančius procesus. Todèl reikia naudoti sukurtus modelius, atspindinčius pokyčius meandrinès lètinimo sistemos su papildomais ekranais gretimų juostelių sujungimo vietoje ir tarpuose ties meandro kilpomis ir atviraja jo dalimi.

3. Meandrinių lètinimo sistemų su papildomais ekranais dažnines savybes galima ištirti jų modelius analizuojant momentų metodu. Fazinès vèlinimo trukmès dažninès priklausomybès nustatymui reikia naudoti sklaidos parametrą $\underline{S}_{21}^{\mathrm{LS}}$, turintį keturpolio perdavimo funkcijos fizikinę prasmę.

4. Norint nustatyti meandrinès lètinimo sistemos su papildomais ekranais iejjimo varžą žemuosiuose dažniuose, reikia keisti apkrovos ir generatoriaus varžas tol, kol gaunama mažiausia sklaidos parametro $\underline{S}_{11}^{\mathrm{LS}}$ vertè. Nustatant iejjimo varžą sistemos kraštuose apkrovos ir generatoriaus varžos turi būti lygios sistemos įejjimo varžai žemuosiuose dažniuose. Tuo tarpu nustatant iejjimo varžą lètinimo sistemos viduryje, generatoriaus varža suderinimo etape turi būti du kartus mažesnè už sistemos iejjimo varžą žemuosiuose dažniuose ir lygi pusei apkrovos varžos.

5. Siekiant pavaizduoti krūvio pasiskirstymą meandrinès lètinimo sistemos gretimų juostelių sujungimo vietoje ir išryškinti elektromagnetini ryši tarp gretimų meandro juostelių, reikia kurti metodikas, leidžiančias apskaičiuoti krūvio pasiskirstymą trimatejje erdvėje. 



\section{Meandrinių lètinimo sistemų su papildomais ekranais savybès}

Šiame skyriuje pateikiami meandrinių lètinimo sistemų su papildomais ekranais tyrimo rezultatai, gauti remiantis antrame skyriuje pasiūlytu dažninių charakteristikų apskaičiavimo algoritmu ir įejjimo varžos nustatymo metodika. Nagrinèjama kaip keičiasi sistemos vẻlinimo trukmè esant skirtingiems papildomų ekranų įžeminimo taškams ir ịvairioms kraštu topologijoms. Taip pat analizuojamos iejjimo varžos ir $\underline{S}_{11}^{\mathrm{LS}}$ parametro priklausomybès kintant dažniui. Be to, pateikiami elektrinio lauko meandrinèse lètinimo sistemose trimačio pasiskirstymo tyrimo rezultatai.

Skyriaus tematika paskelbti keturi autoriaus straipsniai (Metlevskis, Urbanavičius 2011; Metlevskis, Martavičius 2012; Metlevskis, Martavičius 2012; Metlevskis, Martavičius 2014). 


\subsection{Papildomų ekranụ ịžeminimo taško ịtakos sistemos dažninèms charakteristikoms tyrimo rezultatai}

Vieni iš pagrindinių meandrinę lètinimo sistemą apibūdinančių parametrų yra jos fazinio vèlinimo trukmé $t_{\mathrm{v}}$ ir praleidžiamųjų dažnių juostos plotis $\Delta F$. Bendruoju atveju fazinio vẻlinimo trukmè nustatoma arba apskaičiuojama žemuju dažnių srityje. Meandrinès lètinimo sistemos praleidžiamujų dažnių juostos plotị nustato žemesnysis iš dviejų dažnių: dažnio $f_{\text {maxDACh}}$, kuriam esant sistemos dažninè amplitudès charakteristika kerta $-3 \mathrm{~dB}$ lygi, arba dažnio $f_{\text {maxDFCh, }}$ kuriam esant fazès dažninè charakteristika nukrypsta 0,35 radiano nuo tiesinès charakteristikos. Praktika rodo, kad, kai meandrinès linijos fazinè vèlinimo trukmé neviršija kelių dešimčių nanosekundžių, nuostoliai šioje linijoje nedideli ir galima sakyti, kad lètinimo sistemos praleidžiamujų dažnių juostos ploti lemia jos DFCh eiga. Tuomet linijos fazinès vèlinimo trukmès dažninè priklausomybè $t_{\mathrm{v}}(\omega)$ turi atitikti sąlygą (Staras et al. 2010):

$$
\Delta t_{\mathrm{v}} \leq \frac{0,35}{\omega},
$$

čia $\Delta t_{\mathrm{v}}=t_{\mathrm{v}}(\omega)-t_{\mathrm{v} \text { nom }}-$ vèlinimo trukmès pokytis praleidžiamųjų dažnių juostos pločio ribose; $t_{\mathrm{v} \text { nom }}$ - nominali vèlinimo trukmè, $\omega=2 \pi f$ - kampinis dažnis.

Papildomų ekranų įžeminimo taško ịtakai meandrinès lètinimo sistemos dažninèms charakteristikoms nustatyti, buvo ištirta sistema su tokiais konstrukciniais parametrais: meandro laidininko ilgis $2 A=19,6 \mathrm{~mm}$, jo plotis $w_{1}=0,5 \mathrm{~mm}$, papildomo ekrano plotis $w_{2}=0,25 \mathrm{~mm}$, laidininko, jungiančio gretimas meandro juosteles plotis $w_{3}=0,2 \mathrm{~mm}$, tarpo tarp meandro laidininko ir papildomo ekrano plotis $s_{1}=0,2 \mathrm{~mm}$, pagrindo storis $h=0,5 \mathrm{~mm}$, jo santykine dielektrinè skvarba $\varepsilon_{\mathrm{r}}=7,3$. Parinkti konstrukciniai parametrai, esant galimybei, leistų lengvai pagaminti ir ištirti sistemą eksperimento metu. Tokių matmenų sistemą tikslinga analizuoti dažnių ruože iki $3 \mathrm{GHz}$. Norint nagrinèti sistemą platesniame dažnių ruože, proporcingai turètų būti mažinami ir konstrukciniai sistemos parametrai.

Tyrimų metu visi laidininkai laikyti idealiai laidžiais. Taigi tirta sistema be nuostolių, todèl jos praleidžiamujų dažniu juostos plotis $\Delta F$ buvo nustatomas iš DFCh kaip parodyta 3.1 paveiksle. Čia pateikiamos meandrinès lètinimo sistemos be papildomų ekranų idealioji ir realioji DFCh. Iš grafiko matyti, kad $0,35 \mathrm{rad}$ skirtumas tarp idealios ir apskaičiuotos DFCh susidaro ties $1,16 \mathrm{GHz}$, taigi galima teigti, kad nagrinejjamos meandrinès lètinimo sistemos be papildomų ekranų praleidžiamujų dažnių juostos plotis $\Delta F$ taip pat lygus $1,16 \mathrm{GHz}$. 


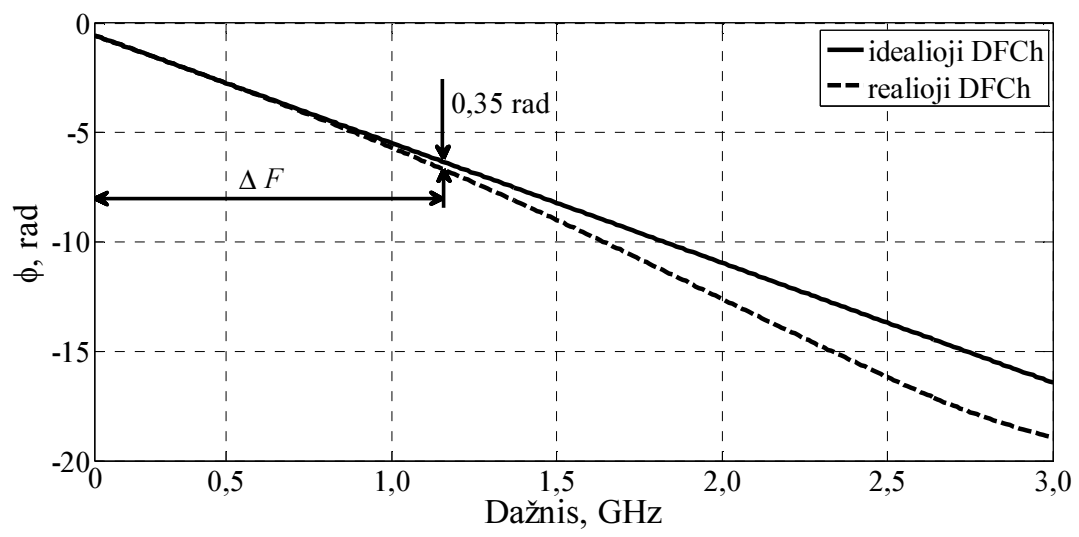

3.1 pav. Meandrinès lètinimo sistemos be papildomų ekranų praleidžiamujų dažniu juostos pločio nustatymas

Fig. 3.1. Bandwidth calculation of meander slow-wave system with additional shields

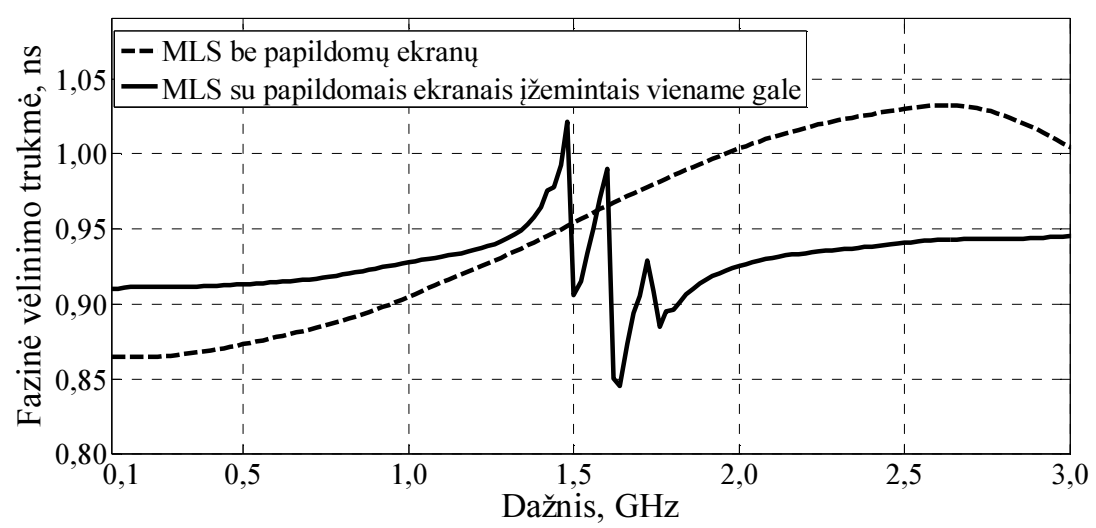

3.2 pav. Meandrinès lètinimo sistemos fazinès vèlinimo trukmès priklausomybè nuo dažnio, kai papildomi ekranai yra ịžeminti viename gale

Fig. 3.2. Phase delay time dependence on the frequency of meander slowwave system with additional shields grounded at one edge.

Meandrinès lètinimo sistemos fazinès vèlinimo trukmès priklausomybė nuo dažnio, kai papildomi ekranai yra ižzeminti viename gale, vietoje kur nèra meandro juostelių sujungimų (2.3 pav., a), pavaizduota 3.2 paveiksle. Palyginimui grafike taip pat pavaizduota kreivè, vaizduojanti tokiu pat matmenų meandrinès lètinimo sistemos be papildomų ekranų fazinę vẻlinimo trukmę kintant dažniui. 
Iš 3.2 paveikslo matyti, kad įterpus papildomus ekranus, sistemos fazinè vèlinimo trukmė žemuosiuose dažniuose padidèja, o jos dispersija sumažeja. Iš DFCh nustatyta, kad įžeminus ekranus viename gale, sistemos pralaidumo juosta tampa 1,17 kartų platesnè lyginant su analogiška meandrine lètinimo sistema be papildomų ekranų ir siekia 1,36 GHz. Taigi praleidžiamųų dažnių juostos pločio ribose fazinès vèlinimo trukmès dispersija sumažeja 1,74 karto. Be to reikètų pastebèti, kad dèl papildomų ekranų ịterpimo 1,4-1,8 GHz dažnių srityje atsiranda rezonansiniai reiškiniai ir lètinimo sistema igyja užtvarinio filtro savybes. Už rezonansinių reiškinių ribos (3.1) sąlyga tenkinama dažnių ruože iki $2,2 \mathrm{GHz}$, todèl tokią sistemą galima naudoti ir aukštesniuose dažniuose.

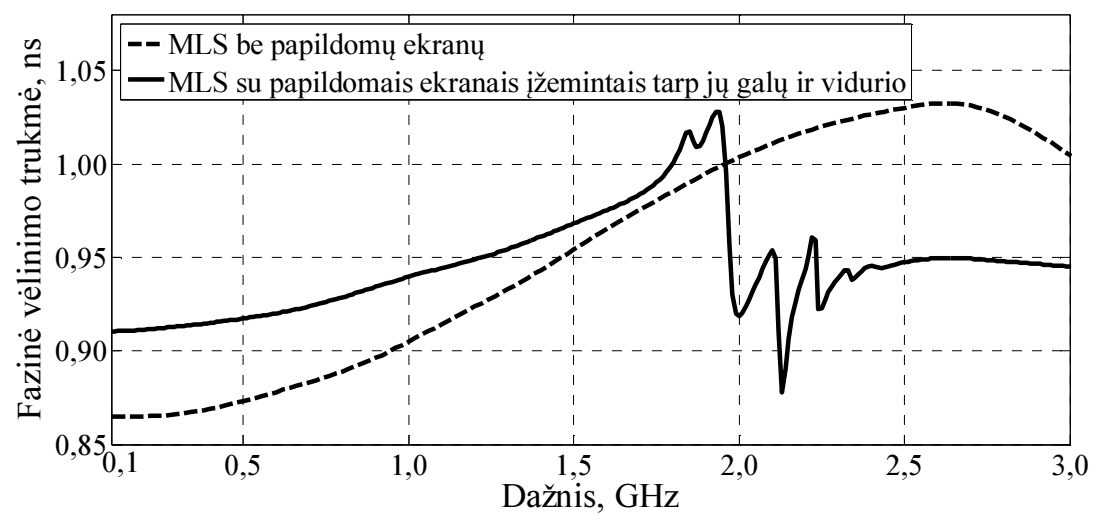

3.3 pav. Meandrinès lètinimo sistemos fazinès vèlinimo trukmès priklausomybè nuo dažnio, kai papildomi ekranai yra ižeminti taške tarp jų galų ir vidurio

Fig. 3.3. Phase delay time dependence on the frequency of meander slowwave system with additional shields grounded at a point between the edge and a center

Fazinès vèlinimo trukmès priklausomybè nuo dažnio, kai meandrinès lètinimo sistemos papildomi ekranai ịžeminami taške tarp jų galų ir vidurio (2.3 pav., c), pateikiama 3.3 paveiksle. Iš paveikslo matyti, kad perkèlus ižeminimo tašką $5 \mathrm{~mm}$ link papildomo ekrano vidurio, sistemos fazinè vèlinimo trukmé žemuosiuose dažniuose padidèja, o jos dispersija sumažèja. Tokios sistemos praleidžiamujjų dažnių juostos plotis $\Delta F=1,3 \mathrm{GHz}$. Taigi lyginant su meandrine lètinimo sistema be papildomų ekranų, pralaidumo juostos plotis padidejja 1,12 karto, o sistemos fazinès vélinimo trukmès dispersija jo ribose sumažèja 1,55 karto. Be to, jžeminus papildomus ekranus tarp jų galų ir vidurio, padidejja lètinimo sistemos rezonansinis dažnis, o rezonansiniai reiškiniai pasislenka i aukštesniuosius dažnius ir pastebimi $1,85-2,45 \mathrm{GHz}$ dažnių ruože. 
Dažnių srityje nuo 2,5 GHz fazinès vèlinimo trukmès dažninès priklausomybès nuokrypis nuo tiesinès charakteristikos yra didesnis nei 0,35 radiano ir ji netenkina (3.1) sąlygos. Dèl to naudoti tokią sistemą aukštesniuose dažniuose nerekomenduojama.

Taip pat reikètų atkreipti dèmesị i tai, kad pralaidumo juostos pločio ribose sistemos su papildomais ekranais įžemintais tarp jų galų ir vidurio fazinès vèlinimo trukmès charakteristika yra statesnè nei sistemos su papildomais ekranais ižemintais viename gale (3.2 pav.). Taigi perkèlus įžeminimo tašką $5 \mathrm{~mm}$ link papildomo ekrano vidurio, sistemos fazinès vèlinimo trukmès dispersija padidèja apie 1,3 karto.

Meandrinès lètinimo sistemos fazinès vèlinimo trukmès priklausomybè nuo dažnio, kai papildomi ekranai yra ižzeminti viduryje (2.3 pav., b), pavaizduota 3.4 paveiksle. Iš paveikslo matyti, kad ižzeminus papildomus ekranus viduryje, sistemos fazinè vẻlinimo trukmè žemuosiuose dažniuose padideja. Lyginant su meandrine letinimo sistema be papildomų ekranų, pralaidumo juostos plotis $\Delta F$ sumažeja iki 1,09 GHz arba 1,06 karto, o fazinès vèlinimo trukmès dispersija šiame dažnių ruože padideja apie 1,1 karto. Be to, papildomų ekranų ižeminimas viduryje rezonansinius reiškinius paslenka dar labiau ị aukštesniuosius dažnius ir jie prasideda nuo 2,8 GHz. Apskritai galima teigti, kad pralaidumo juostos pločio ribose abiejų sistemų fazinès vèlinimo trukmès kitimo pobūdis išlieka panašus, tačiau papildomų ekranų ižeminimas viduryje jos vertę padidina nuo 0,86 iki 0,91 ns arba apie $6 \%$.

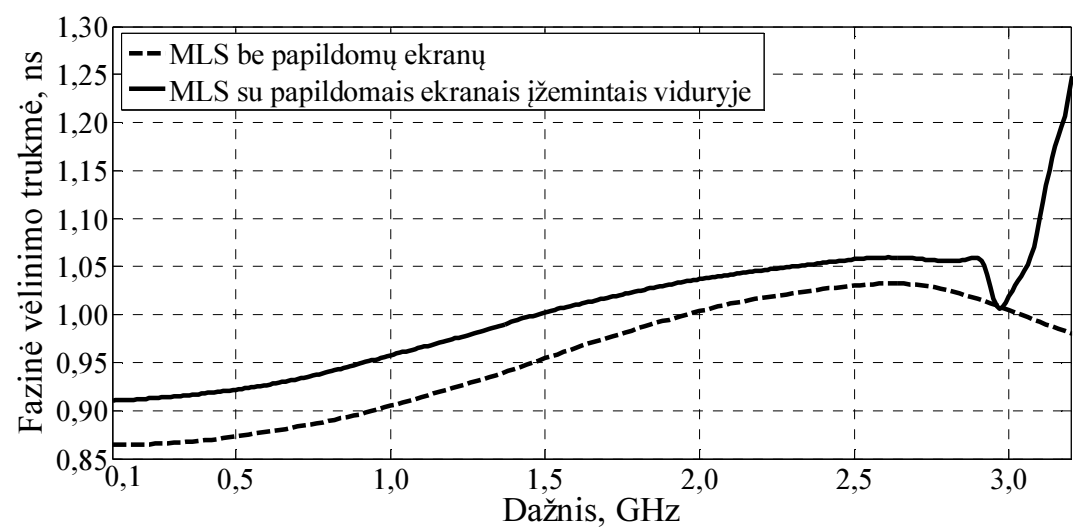

3.4 pav. Meandrinès lètinimo sistemos fazinès vèlinimo trukmès priklausomybė nuo dažnio, kai papildomi ekranai yra įžeminti centre

Fig. 3.4. Phase delay time dependence on the frequency of meander slowwave system with additional shields grounded at the center 
Meandrinès lètinimo sistemos su papildomais ekranais įžemintais viduryje dispersinès savybès yra prastesnès ir lyginant su kitomis sistemomis. Praleidžiamujų dažnių juostos pločio ribose fazinès vèlinimo trukmès dispersija padidèja apie 2,5 karto lyginant su sistema, kurios papildomi ekranai izžeminti viename gale ir 1,6 karto lyginant su sistema, kurios papildomi ekranai įžeminti tarp jų galų ir vidurio.

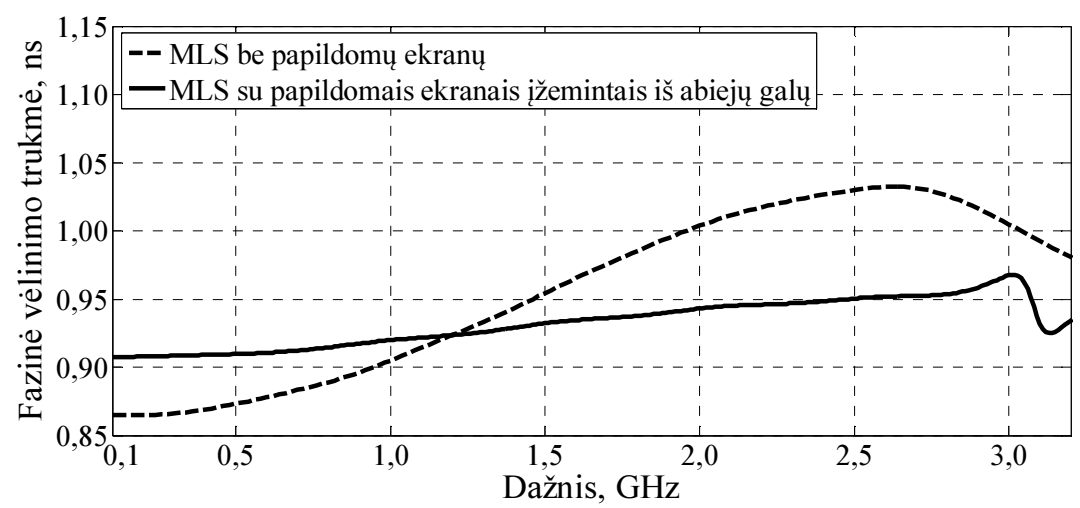

3.5 pav. Meandrinès lètinimo sistemos fazinès vélinimo trukmès priklausomybè nuo dažnio, kai papildomi ekranai yra įžeminti iš abiejų galų Fig. 3.5. Phase delay time dependence on the frequency of meander slowwave system with additional shields grounded at both edges

Fazinès vèlinimo trukmès priklausomybè nuo dažnio, kai meandrinès lètinimo sistemos papildomi ekranai įžeminami iš abiejų galų (2.3 pav, d), pateikiama 3.5 paveiksle. Iš paveikslo matyti, kad dèl papildomų ekranų iterpimo, sistemos fazinio vélinimo trukmè žemuosiuose dažniuose padidejja, o atsiradę rezonansiniai reiškiniai prasideda nuo $2,8 \mathrm{GHz}$. Iš DFCh nustatyta, kad nagrinèjamos sistemos pralaidumo juosta $\Delta F=1,97 \mathrm{GHz}$. Fazinès vèlinimo trukmés dispersija šiame dažnių ruože yra $\Delta t_{\mathrm{v}}=0,035 \mathrm{~ns}$. Meandrinèje lètinimo sistemoje be papildomų ekranų fazinès vèlinimo trukmès dispersija tame pačiame dažnių ruože didesnè ir yra 0,135 ns. Taigi ịterpus ị sistemą papildomus ekranus, įžemintus iš abiejų galų, lètinimo sistemos fazinès vèlinimo trukmès dispersija dažnių ruože iki 1,97 GHz sumažèja apie 3,89 karto.

Rezultatų palyginimui, visu ištirtų modelių fazinès vèlinimo trukmès priklausomybès nuo dažnio kreivès pavaizduotos viename grafike, 3.6 paveiksle. Be to, fazinès vèlinimo trukmès žemuosiuose dažniuose ir pralaidumo juostos pločio vertès esant skirtingiems papildomų ekranų ižeminimo taškams pateiktos 3.1 lentelèje. 


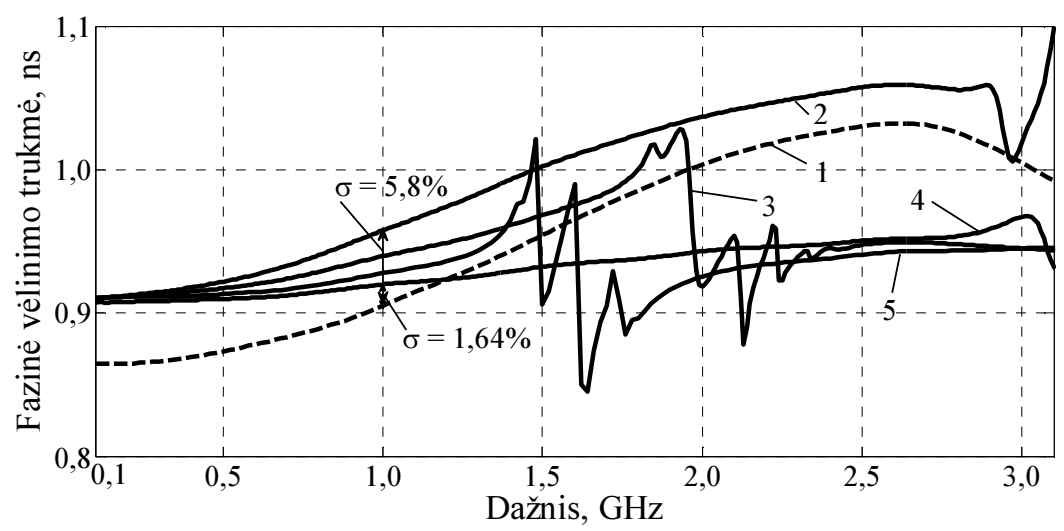

3.6 pav. Meandrinių lètinimo sistemų fazinès vèlinimo trukmès palyginimas, kai tiriama sistema: 1 - be papildomų ekranų; su papildomais ekranais įžemintais: 2 - viduryje; 3 - tarp jų galų ir vidurio; 4 - iš abiejų galų; 5 - viename gale

Fig. 3.6. Comparison of phase delay time of meander slow-wave systems:

1 - without additional shields; with additional shields grounded at: 2 - center; 3 - point between the edge and the center; 4 - both edges;

5 - one edge

3.1 lentelè. Meandrinių lètinimo sistemų fazinès vèlinimo trukmès žemuosiuose dažniuose ir pralaidumo juostos pločio vertès esant skirtingiems papildomų ekranų ižeminimo taškams

Table 3.1. Values of phase delay time in lower frequencies and bandwidth of meander slow-wave system with different grounding points of additional shields

\begin{tabular}{|c|c|c|}
\hline Papildomo ekrano ịžeminimo taškas & $t_{\mathrm{v} \check{\mathrm{D}} \mathrm{D}} \mathrm{ns}$ & $\Delta F, \mathrm{GHz}$ \\
\hline Be papildomų ekranų & 0,865 & 1,16 \\
\hline Viename gale & 0,910 & 1,36 \\
\hline Tarp galo ir vidurio & 0,910 & 1,30 \\
\hline Viduryje & 0,911 & 1,09 \\
\hline Iš abiejų galų & 0,907 & 1,97 \\
\hline
\end{tabular}

Iš 3.6 paveiksle ir 3.1 lentelëje pateiktų duomenų matyti, kad apskritai papildomų ekranų įterpimas didina sistemos fazinę vėlinimo trukmę žemuosiuose dažniuose apie $5 \%$. Dažnių ruože iki $1 \mathrm{GHz}$, santykinis vėlinimo trukmès padidejjimas kinta nuo 1,64 \%, kai papildomi ekranai įžeminami iš abiejų galų iki $5,8 \%$, esant papildomų ekranų įžeminimui viduryje. Aukštesniuose dažniuose, 
už rezonansinių reiškinių ribos, papildomų ekranų ịterpimas mažina sistemos fazinę vèlinimo trukmę, išskyrus atveji kai papildomi ekranai įžeminami viduryje. Šiuo atveju fazinès vèlinimo trukmès vertè yra didesnè visame nagrinèjamame dažnių ruože.

Iš 3.1 lentelès taip pat matyti, kad beveik visų meandrinių lètinimo sistemų su papildomais ekranais praleidžiamujų dažnių juosta yra platesnè už tokių pat konstrukcinių parametrų meandrinès lètinimo sistemos be papildomų ekranų. Siauresne nei meandrinès lètinimo sistemos be papildomų ekranų pralaidumo juosta pasižymi tik viena iš tirtų sistemų, kurioje papildomi ekranai įžeminami viduryje. Plačiausia praleidžiamųjų dažnių juosta pasižymi sistema, kurioje papildomi ekranai yra įžeminami iš abiejų galų.

Apibendrinant galima teigti, kad geresnèmis dispersinėmis savybèmis pasižymi meandriné lètinimo sistema su papildomais ekranais, įžemintais iš abiejų galų. Šios sistemos fazinès vèlinimo trukmès dispersija yra mažiausia. Be to, ji pasižymi plačiausia praleidžiamųjų dažnių juosta. Tokią sistemą gali būti naudojama dažnių ruože iki 1,97 GHz.

\subsection{Kraštų topologijų ịtakos sistemos dispersinėms savybèms tyrimo rezultatai}

3.1 poskyryje buvo nustatyta, kad geresnėmis dispersinėmis savybėmis pasižymi lètinimo sistema, kurioje papildomų ekranų abu galai yra sujungti su išorinių ekranu (2.3 pav., d). Todèl šiame poskyryje pateikiami tokios meandrinès lètinimo sistemos kraštu topologijos ịtakos dispersinèms savybėms tyrimo rezultatai.

3.7 paveiksle pavaizduota fazinès vèlinimo trukmès priklausomybė nuo dažnio, keičiant laidininko, jungiančio gretimas meandro juosteles plotị $w_{3}$ (2.4 pav.). Fazinès vẻlinimo trukmès žemuosiuose dažniuose ir pralaidumo juostos pločio vertès, gauti šio eksperimento metu, pateiktos 3.2 lentelèje. Iš pateiktų duomenų matyti, kad keičiantis pločiui $w_{3}$, sistemos fazinè vélinimo trukmè didejja.

Sumažinus jungiančio laidininko plotị 8 kartus, fazinè vèlinimo trukmè padidèja $0,8 \%$. Tačiau toks $w_{3}$ mažinimas siaurina sistemos pralaidumo juostą $7 \%$ iki $1,82 \mathrm{GHz}$. Minètas fazinès vèlinimo trukmès padidèjimas išlieka pastovus visame pralaidumo juostos dažnių ruože.

Padidinus jungiančio laidininko plotị $w_{3} 3$ kartus, vèlinimo trukmé padidèja $1,4 \%$, tačiau praleidžiamujų dažnių juostos plotis sumažèja dar labiau - iki $1,72 \mathrm{GHz}$ arba $13 \%$. Taigi galima daryti išvadą, kad didesnis efektas pastebimas didinant jungiančio laidininko plotị $w_{3}$. Jis paaiškinamas talpinių netolygumų sudarymu meandriniame laidininke. 


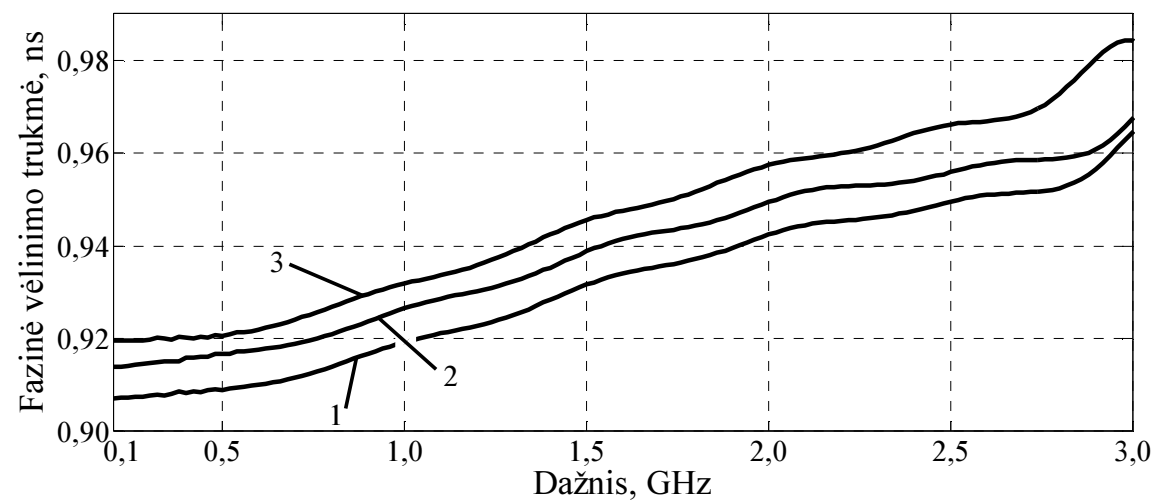

3.7 pav. Fazinės vẻlinimo trukmès priklausomybė nuo dažnio, keičiant laidininko, jungiančio gretimas meandro juosteles, plotị $w_{3}: 1-$ sistema su pradiniais konstrukciniais parametrais; $2-w_{3}=0,025 \mathrm{~mm}$;

$$
3-w_{3}=0,6 \mathrm{~mm}
$$

Fig. 3.7. Phase delay time dependence on frequency when width $w_{3}$ of a conductor connecting adjacent meander strips is changed: 1 - system with initial dimensions; $2-w_{3}=0.025 \mathrm{~mm} ; 3-w_{3}=0.6 \mathrm{~mm}$

3.2 lentelè. Meandrinių lètinimo sistemų su papildomais ekranais, įžemintais iš abiejų galų fazinès vėlinimo trukmès žemuosiuose dažniuose ir pralaidumo juostos pločio vertès keičiant laidininko, jungiančio gretimas meandro juosteles plotị $w_{3}$

Table 3.2. Values of phase delay time in lower frequencies and bandwidth of meander slow-wave system with additional shields grounded at both edges when width $w_{3}$ of a conductor connecting adjacent meander strips is changed

\begin{tabular}{|c|c|c|c|}
\hline $\begin{array}{c}\text { Lètinimo } \\
\text { sistemos } \\
\text { žymèjimas }\end{array}$ & $w_{3}, \mathrm{~mm}$ & $t_{\mathrm{v} \check{\mathrm{D}} \mathrm{,ns}}$ & $\Delta F, \mathrm{GHz}$ \\
\hline 1 & 0,2 & 0,907 & 1,97 \\
\hline 2 & 0,025 & 0,914 & 1,82 \\
\hline 3 & 0,6 & 0,919 & 1,72 \\
\hline
\end{tabular}

Fazinès vèlinimo trukmès priklausomybè nuo dažnio, didejjant tarpui meandrinès lètinimo sistemos kraštuose ties gretimų meandro laidininkų sujungimais (2.5 pav.), pateikiama 3.8 paveiksle. Kartu, 3.3 lenteleje, pateikiamos ištirtų sistemų fazinès vèlinimo trukmès žemuosiuose dažniuose ir pralaidumo juostos pločio vertès. 
Iš lenteleje pateiktų duomenų matyti, kad didejjant dydžiui $\Delta s$, o kartu ir tarpui, fazinè vèlinimo trukmė žemuosiuose dažniuose taip pat didejja. Tarpo pločiui $\Delta s$ padidejjus 1,5 karto, vèlinimo trukmé padidejja $0,8 \%$, tuo tarpu ploti padidinus 2,5 karto, vélinimo trukmé padidèja 2,7 \%. Iš 3.8 paveiksle pateikto grafiko matyti, kad toks vèlinimo trukmių padidejjimas išlieka pastovus vidutiniujų bei aukštesniujų dažnių ruože. Tačiau toks topologijos keitimas šiek tiek siaurina sistemos pralaidumo juostą. Pirmuoju atveju pralaidumo juosta susiaurèja iki $1,81 \mathrm{GHz}$ arba $8,2 \%$, antruoju - iki $1,73 \mathrm{GHz}$ arba $12,2 \%$.

Dèl topologijos pasikeitimų padidèjusị fazinę vèlinimo trukmę galima sumažinti, mažinant juostelių ilgi $2 A$. Tokiu būdu žemuosiuose dažniuose suvienodinto fazinès vèlinimo trukmès priklausomybè nuo dažnio pateikiama 3.8 paveiksle, 4 kreive. Dispersinès savybès šiuo atveju nepagerejja, tačiau galima sumažinti bendrą sistemos plotą. Iš 3.3 lentelès matyti, kad vienodos fazinès vèlinimo trukmès vertès žemuosiuose dažniuose gaunamos sumažinus juostelių ilgi $2 A$ iki $19 \mathrm{~mm}$, dèl ko bendras sistemos plotas sumažèja $3 \%$. Tai labai svarbu taikant meandrines lètinimo sistemas šiuolaikiniuose integriniuose grandynuose.

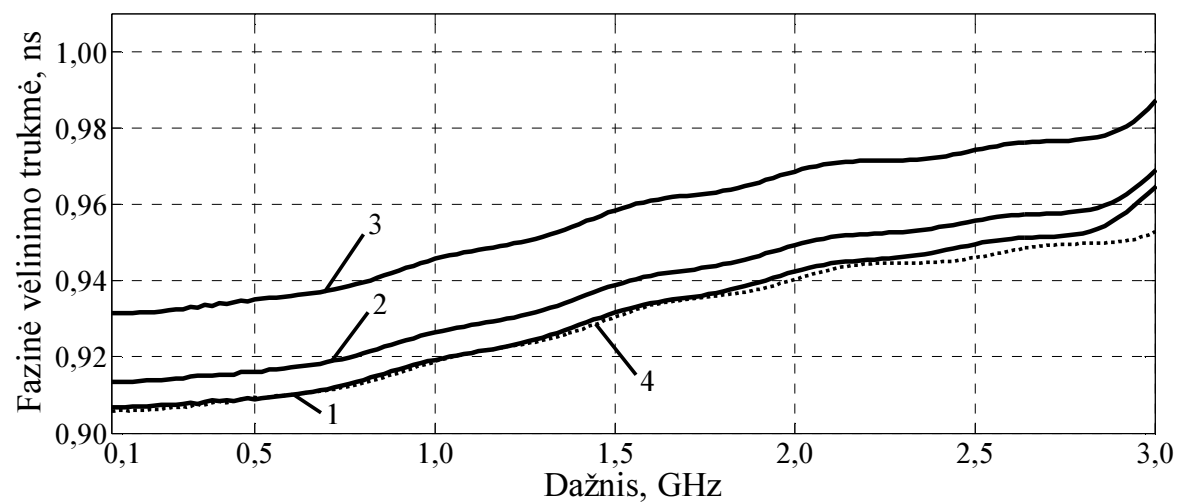

3.8 pav. Fazinès vèlinimo trukmès priklausomybè nuo dažnio, didinant tarpą meandrinès lètinimo sistemos kraštuose ties gretimų meandro laidininkų sujungimais: 1 - sistema su pradiniais konstrukciniais parametrais; $2-\Delta s=0,3 \mathrm{~mm}, \Delta A=0,6 \mathrm{~mm}, 2 A=19,6 \mathrm{~mm}$; $3-\Delta s=0,5 \mathrm{~mm}, \Delta A=0,6 \mathrm{~mm}, 2 A=19,6 \mathrm{~mm} ; 4-\Delta s=0,5 \mathrm{~mm}$, $\Delta A=0,6 \mathrm{~mm}, 2 A=19 \mathrm{~mm}$

Fig. 3.8. Phase delay time dependence on frequency when a width of a gap is increased in the area where strips of meander form a loop: 1 -system with initial dimensions; $2-\Delta s=0.3 \mathrm{~mm}, \Delta A=0.6 \mathrm{~mm}, 2 A=19.6 \mathrm{~mm}$;

$3-\Delta s=0.5 \mathrm{~mm}, \Delta A=0.6 \mathrm{~mm}, 2 A=19.6 \mathrm{~mm} ; 4-\Delta s=0.5 \mathrm{~mm}$, $\Delta A=0.6 \mathrm{~mm}, 2 A=19 \mathrm{~mm}$ 
3.3 lentelè. Meandrinių lètinimo sistemų su papildomais ekranais ižemintais iš abiejų galų fazinès vèlinimo trukmès žemuosiuose dažniuose ir pralaidumo juostos pločio vertès keičiantis tarpui ties meandro laidininkų sujungimais

Table 3.3. Values of phase delay time in lower frequencies and bandwidth of meander slow-wave system with additional shields grounded at both edges when a width of a gap in the area where strips of meander form a loop is changed

\begin{tabular}{|c|c|c|c|c|c|}
\hline $\begin{array}{l}\text { Lètinimo } \\
\text { sistemos } \\
\text { žymèjimas }\end{array}$ & $2 A, \mathrm{~mm}$ & $\Delta A, \mathrm{~mm}$ & $\Delta s, \mathrm{~mm}$ & $t_{\mathrm{v} \check{\mathrm{D}} \mathrm{D}}, \mathrm{ns}$ & $\Delta F, \mathrm{GHz}$ \\
\hline 1 & \multirow{3}{*}{19,6} & \multirow{4}{*}{0,6} & 0,2 & 0,907 & 1,97 \\
\hline 2 & & & 0,3 & 0,914 & 1,81 \\
\hline 3 & & & 0,5 & 0,932 & 1,73 \\
\hline 4 & 19 & & 0,5 & 0,907 & 1,71 \\
\hline
\end{tabular}

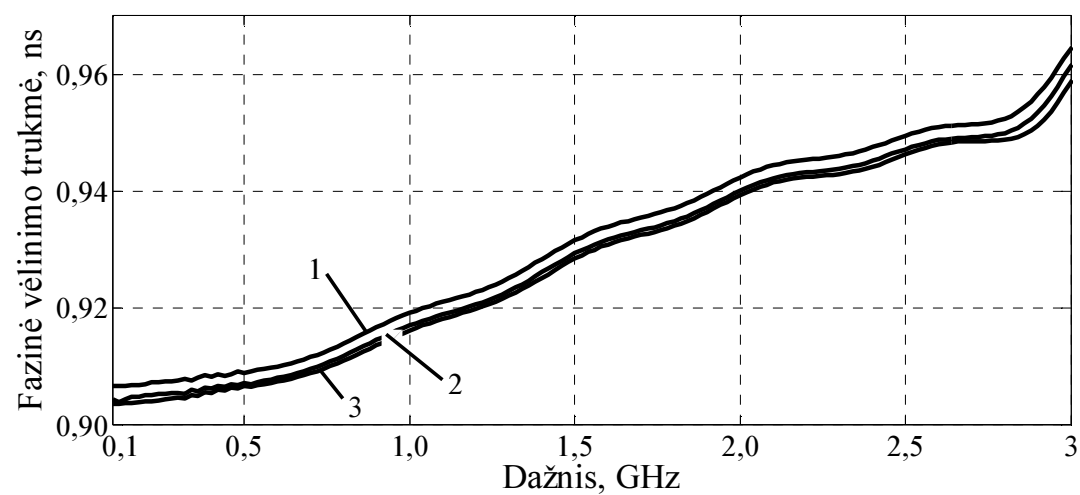

3.9 pav. Fazinès vèlinimo trukmès priklausomybè nuo dažnio, didinant tarpą meandrinès lètinimo sistemos kraštuose ties atvira meandro dalimi: 1 - sistema su pradiniais parametrais; $2-\Delta s=0,3 \mathrm{~mm}, \Delta A=0,6 \mathrm{~mm}$;

$$
3-\Delta s=0,5 \mathrm{~mm}, \Delta A=0,6 \mathrm{~mm}
$$

Fig. 3.9. Phase delay time dependence on frequency when a width of a gap is increased in the area where meander strips are open: $1-$ system with initial dimensions; $2-\Delta s=0.3 \mathrm{~mm}, \Delta A=0.6 \mathrm{~mm} ; 3-\Delta s=0.5 \mathrm{~mm}$,

$$
\Delta A=0.6 \mathrm{~mm}
$$

3.9 paveiksle pavaizduota fazinès vèlinimo trukmès priklausomybė nuo dažnio, didinant tarpą meandrinès lètinimo sistemos kraštuose ties atvira meandro dalimi (2.6 pav.). Tuo pačiu, 3.4 lentelejje palyginamos skaičiavimų metu gautos fazinès vèlinimo trukmès žemuosiuose dažniuose bei pralaidumo juostos pločio vertès. 
3.4 lentelè. Meandrinių lètinimo sistemų su papildomais ekranais ižemintais iš abiejų galụ fazinès vèlinimo trukmès žemuosiuose dažniuose ir pralaidumo juostos pločio vertès keičiantis tarpui ties atvira meandro dalimi

Table 3.4. Values of phase delay time in lower frequencies and bandwidth of meander slow-wave system with additional shields grounded at both edges when a width of a gap in the area where strips of meander are open is changed

\begin{tabular}{|c|c|c|c|c|}
\hline $\begin{array}{l}\text { Lètinimo } \\
\text { sistemos } \\
\text { žymėjimas }\end{array}$ & $\Delta A, \mathrm{~mm}$ & $\Delta s, \mathrm{~mm}$ & $t_{\mathrm{v} \check{Z} \mathrm{D}}, \mathrm{ns}$ & $\Delta F, \mathrm{GHz}$ \\
\hline 1 & \multirow{3}{*}{0,6} & 0,2 & 0,907 & 1,97 \\
\hline 2 & & 0,3 & 0,904 & 1,80 \\
\hline 3 & & 0,5 & 0,903 & 1,80 \\
\hline
\end{tabular}

Iš 3.4 lentelès matyti, kad priešingai nei tarpo pločio didinimu ties meandro laidininkų sujungimais atveju (3.3 lentelè), tarpo pločio didinimas ties atvira meandro dalimi mažina sistemos fazinę vèlinimo trukmę. Tačiau pastebima mažesnè įtaka sistemos dispersinèms savybèms. Pavyzdžiui, padidinus tarpo plotị ties atvira meandro dalimi 2,5 karto, sistemos vẻlinimo trukmé sumažèja vos $0,4 \%$, kai toks pat pločio padidejjimas ties meandro laidininko sujungimais padidina sistemos fazinę vèlinimo trukmę $2,7 \%$. Sistemos praleidžiamujų dažnių juostos plotis abiem nagrinètais atvejais irgi mažejja - iki 1,8 GHz.

Iš 3.9 paveikslo matyti, kad fazinès vèlinimo trukmès sumažèjimas pastebimas visame nagrinejjamame dažnių ruože. Taigi pasikeitimas šioje meandrinės lètinimo sistemos su papildomais ekranais topologijos dalyje turi mažai ịtakos sistemos dispersinėms savybėms. Tai paaiškinama maža elektromagnetine sąveika šioje lètinimo sistemos srityje. Todèl daryti topologijos pakeitimus sistemos kraštuose, ties atvira meandro dalimi nerekomenduojama.

\section{3. lëjimo varžos dažninès charakteristikos}

3.10 paveiksle pateikiama $S_{11}$ parametro priklausomybè nuo dažnio, nustatant žemuosiuose dažniuose meandrinès lètinimo sistemos su papildomais ekranais iejjimo varžą jos kraštuose. Atliekant sistemos analizę momentų metodu, Sonnet $^{\circledR}$ modeliavimo terpeje pagal nutylejimą laikoma, kad generatoriaus ir apkrovos varžos lygios $50 \Omega$. $S_{11}$ parametras, atitinkantis tokias varžų vertes, pavaizduotas 3.10 paveiksle pateiktame grafike, 1 kreive. Suderintos sistemos $S_{11}$ parametro priklausomybė nuo dažnio yra pavaizduota 2 kreive. Iš grafiko matyti, kad suderinus apkrovos ir generatoriaus varžas, $S_{11}$ parametro verte žemuosiuose dažniuose sumažèja praktiškai iki 0 . 


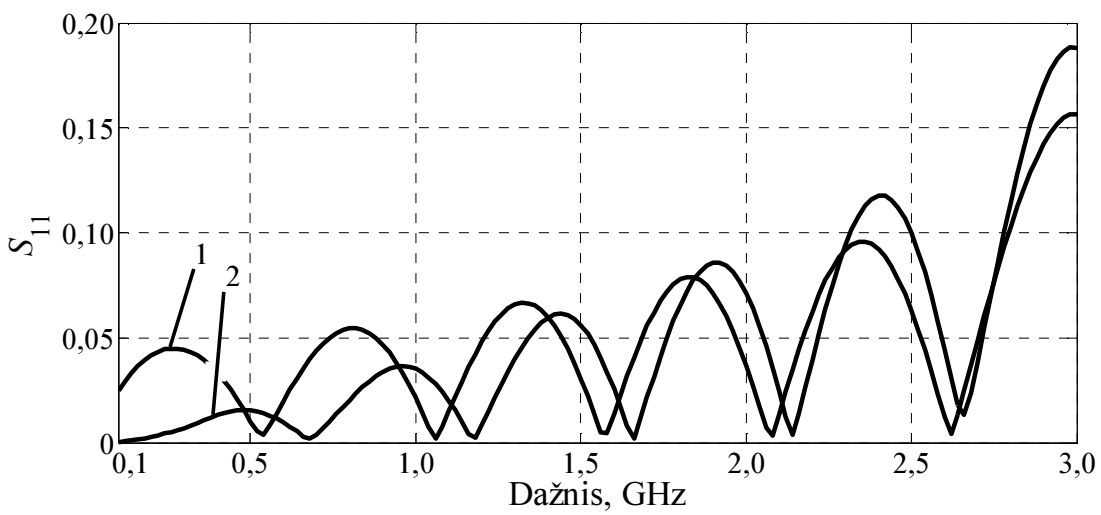

3.10 pav. $S_{11}$ parametro priklausomybè nuo dažnio, nustatant žemuosiuose dažniuose meandrinès lètinimo sistemos su papildomais ekranais įejjimo varžą jos kraštuose: 1 - kai $R_{\mathrm{g}}=R_{\mathrm{a}}=50 \Omega ; 2$ - esant suderintoms apkrovos ir generatoriaus varžoms $R_{\mathrm{g}}=R_{\mathrm{a}}=48 \Omega$

Fig. 3.10. Frequency response of $\mathrm{S} 11$ parameter when determining input impedance in the lower frequencies on the edges of a meander slow-system with additional shields: 1 - when $R_{\mathrm{g}}=R_{\mathrm{a}}=50 \Omega$; when load and source resistances are matched to the system's input impedance $R_{\mathrm{g}}=R_{\mathrm{a}}=48 \Omega$

$S_{11}$ parametro priklausomybė nuo dažnio, nustatant žemuosiuose dažniuose meandrinès lètinimo sistemos su papildomais ekranais iejjimo varžą jos viduryje, yra pateikta 3.11 paveiksle. Šiuo atveju 1 kreivė atitinka atveji, kuomet apkrovos varžos $R_{\mathrm{a}}=50 \Omega$, o generatoriaus varža $R_{\mathrm{g}}=25 \Omega$ (2.1 lentelè). Kreivè 2 atvaizduoja $S_{11}$ parametro priklausomybę nuo dažnio esant suderintoms apkrovos ir generatoriaus varžoms. Iš 3.11 paveiksle pateikto grafiko matyti, kad ir šiuo atveju suderinus apkrovos ir generatoriaus varžas, $S_{11}$ parametro verte žemuosiuose dažniuose taip pat sumažèja.

Meandrinès lètinimo sistemos su papildomais ekranais iejjimo varžos dažninių charakteristikų tyrimo rezultatai pateikiami 3.12 ir 3.13 paveiksluose. 3.12 paveiksle pateiktame grafike pavaizduota iejjimo varžos priklausomybè nuo dažnio sistemos kraštuose. Grafiko 1 kreivè parodo aktyviosios $R$, o 2 - reaktyviosios $X$ varžų pokyčius. Iš grafiko matyti, kad iejjimo varža tiriamos sistemos kraštuose išlieka beveik pastovi dažnių ruože iki $1,5 \mathrm{GHz}$ ir yra artima $48 \Omega$. Aukštesniuose dažniuose pastebimi iejimo varžos svyravimai. İejimo varžos ties sistemos kraštais svyravimus nulemia sistemos kraštų, kuriuose pakinta elektromagnetinio lauko struktūra, efektai ir elektromagnetinis ryšys tarp gretimų meandrinio laidininko juostelių, dèl kurių atsiranda iejjimo varžos nesuderinamumas su generatoriaus ir apkrovos varžomis ir sistemoje vyksta krentančios ir 


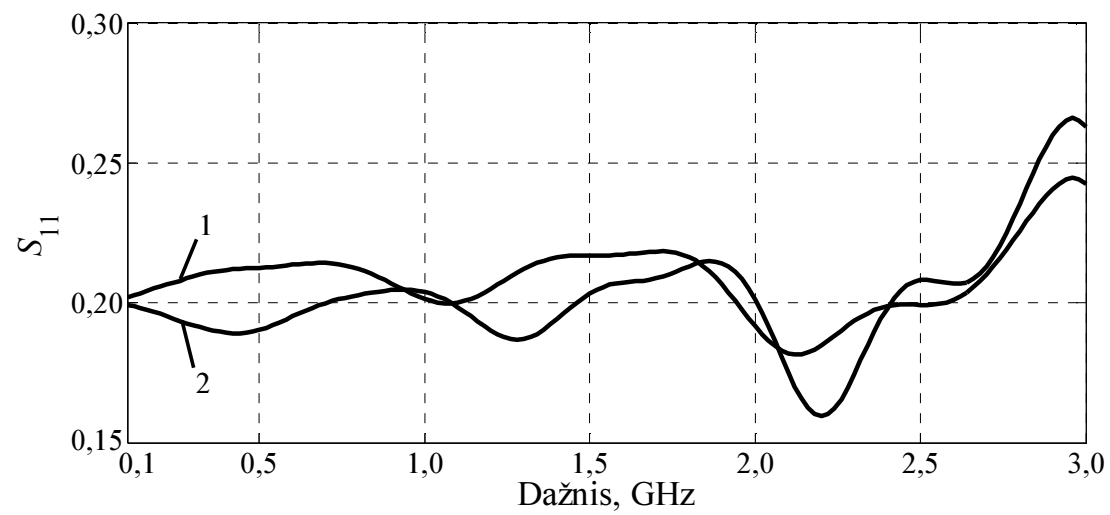

3.11 pav. $S_{11}$ parametro priklausomybè nuo dažnio, nustatant žemuosiuose dažniuose meandrinès lètinimo sistemos su papildomais ekranais iejjimo varžą jos viduryje: 1 - kai $R_{\mathrm{a}}=50 \Omega, R_{\mathrm{g}}=25 \Omega ; 2$ - esant suderintoms apkrovos ir generatoriaus varžoms $R_{\mathrm{a}}=46,7 \Omega, R_{\mathrm{g}}=23,35 \Omega$

Fig. 3.11. Frequency response of $S_{11}$ parameter when determining input impedance in the lower frequencies in the center of a meander slow-wave system with additional shields: 1 - when $R_{\mathrm{a}}=50 \Omega, R_{\mathrm{g}}=25 \Omega ; 2$ - when load and source resistances are matched to the system's input impedance

$$
R_{\mathrm{a}}=46.7 \Omega, R_{\mathrm{g}}=23.35 \Omega
$$

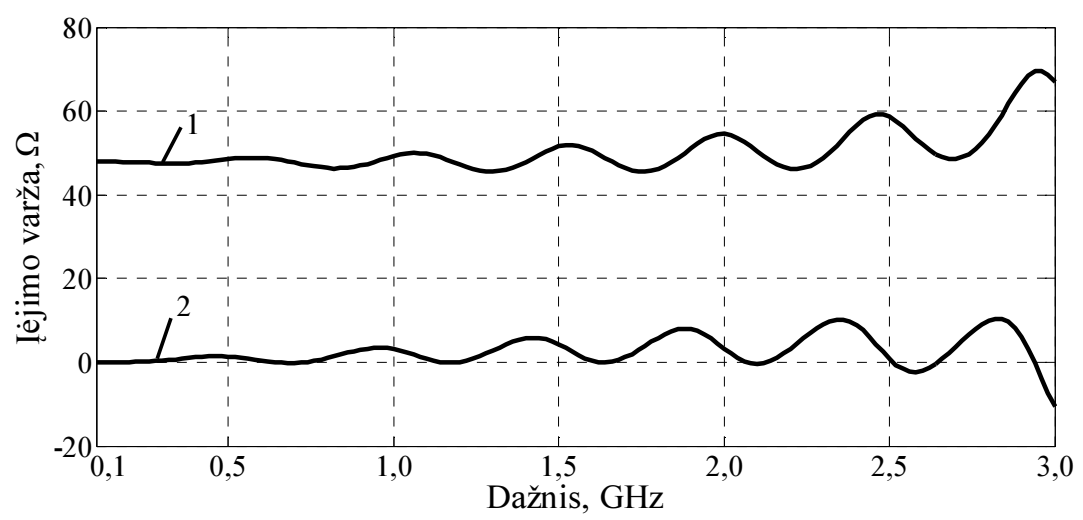

3.12 pav. İejjimo varžos priklausomybè nuo dažnio meandrinès lètinimo sistemos su papildomais ekranais kraštuose: 1 - aktyvioji varža $R$;

2 - reaktyvioji varža $X$

Fig. 3.12. Frequency response of the input impedance on the edges of a meander slow-wave system with additional shields: 1 - resistance $R$; 


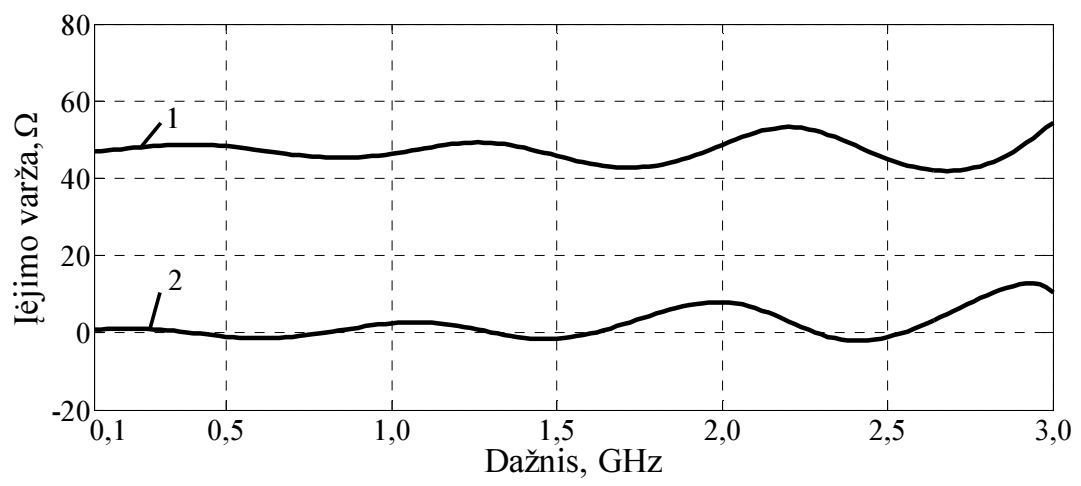

3.13 pav. İejimo varžos priklausomybè nuo dažnio meandrinès lètinimo sistemos su papildomais ekranais viduryje: 1 - aktyvioji varža $R$;

\section{2 - reaktyvioji varža $X$}

Fig. 3.13. Frequency response of the input impedance in the center of a meander slow-wave system with additional shields: 1 - resistance $R$;

2 - reactance $X$.

atsispindejjusios bangų superpozicija. Be to, reikètų pastebèti, kad sistemos įejjimo varžos reaktyvioji dalis yra labai maža ir visame dažnių ruože yra arti nulio, todèl galima daryti išvadą, kad iẹjimo varža meandrinès lètinimo sistemos su papildomais ekranais kraštuose yra beveik aktyvioji.

3.13 paveiksle pateikiama iejjimo varžos priklausomybè nuo dažnio meandrinès lètinimo sistemos su papildomais ekranais viduryje. Šiuo atveju matome, kad iejjimo varža tiriamos sistemos viduryje išlieka pastovi platesniame dažniu ruože - iki $2 \mathrm{GHz}$. Tai paaiškinama tuo, kad šioje vietoje nèra kraštų efektų turinčių įtakos iejjimo varžai. Sistemos viduryje ièjimo varža kinta dèl elektromagnetinio ryšio tarp gretimų meandrinio laidininko juostelių. İejimo varžos verte žemuosiuose dažniuose yra tokia pati kaip ir sistemos kraštuose. Reaktyvioji iejjimo varžos dalis sistemos viduryje, kaip ir kraštuose yra arti nulio, todèl įejjimo varža meandrinès lètinimo sistemos su papildomais ekranais viduryje taip pat yra beveik aktyvioji.

\subsection{Elektrinio lauko meandrinèse lètinimo sistemose trimačio pasiskirstymo tyrimo rezultatai}

Siekiant ištirti elektrinio lauko pasiskirstymą, buvo sudarytas meandrinès lètinimo sistemos modelis, kurio sandara aprašoma 2.1.1 skyrelyje. Meandras bu- 
vo sudarytas iš 12 juostelių, kurių konstrukciniu parametrų santykis yra toks: $A / h=4, w / h=1, s / h=0,25$. Viena meandro laidininko juostelè $x$ ašies kryptimi yra padalinta ị 8 dalines sritis, $y$ ašies kryptimi - į 80 dalinių sričių.

Krūvio pasiskirstymas, kai ị meandro formos laidininką siunčiamas $+1 \mathrm{~V}$ potencialas, pavaizduotas 3.14 paveiksle. Iš paveikslo matyti, kad didesnis krūvis yra sukauptas šoninèse meandro juostelèse. Be to, reikètų atkreipti dèmesi i staigu krūvio padidejjimą laidininkų kraštuose. Toks padidejimas parodo, kad siūloma metodika ịvertina elektrinio lauko sklaidą laidžios struktūros kraštuose.

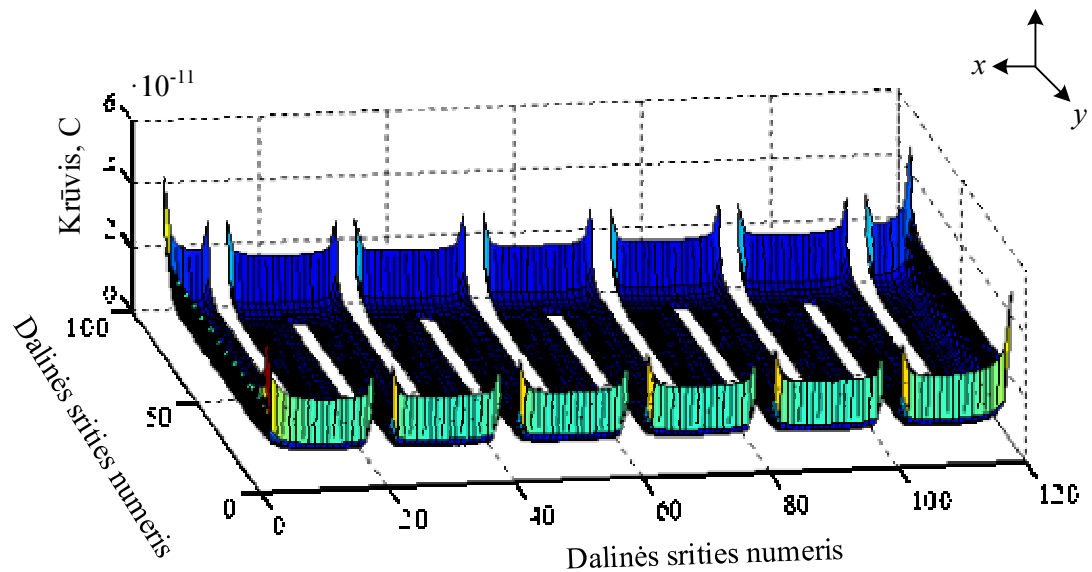

3.14 pav. Krūvio pasiskirstymas meandrinèje lètinimo sistemoje ị laidininką siunčiant $+1 \mathrm{~V}$ potencialą

Fig. 3.14. Surface charge distribution on meander slow-wave system when potential of $+1 \mathrm{~V}$ is applied to the conductor

Krūvio pasiskirstymas meandro laidininko dalyje, kur sujungiamos dvi gretimos meandro juostelès pateiktas 3.15 paveiksle. Čia išryškintas krūvio pasiskirstymas vidiniuose meandro kampuose bei šoninejje juosteleje. Iš paveikslo taip pat matyti, kad ties vidiniu meandro kampu krūvis sumažeja. Toks sumažèjimas aiškinamas tuo, kad gretimuose juostelių kraštuose esantys vienodo ženklo krūviai mažina vienas kitą.

Be to, 3.15 paveiksle aiškiau matomas krūvio pasiskirstymas kiekvienoje juostelèje. Šiuo atveju didesnis krūvis kaupiasi juostelių kraštuose. Tai paaiškinama tuo, kad i nagrinejjamą lètinimo sistemą siunčiamas $+1 \mathrm{~V}$ potencialas ir vienodo ženklo krūviai stumia vienas kitą laidininkų kraštų ir kampų link. 


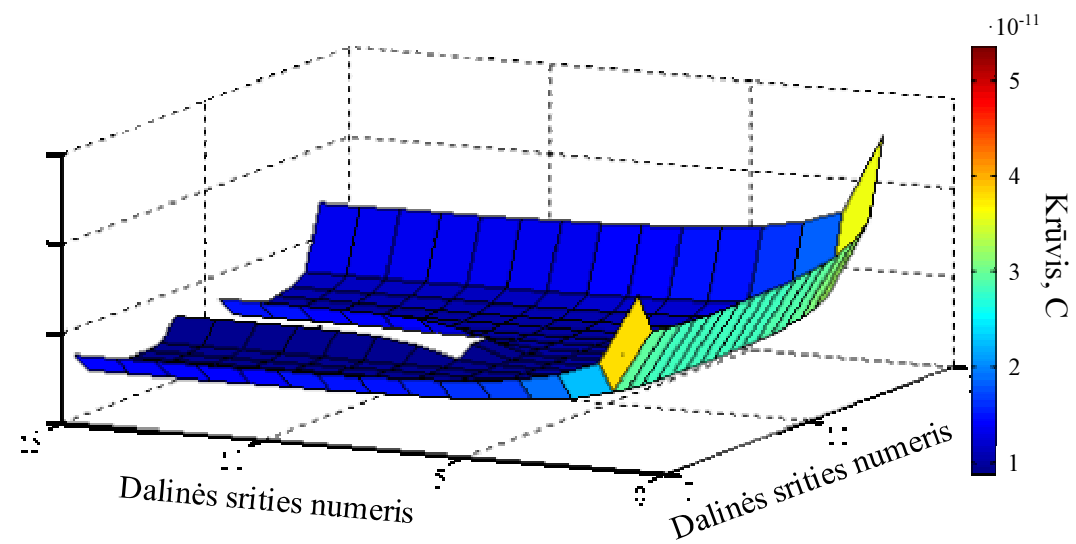

3.15 pav. Krūvio pasiskirstymas meandro laidininko dalyje, kur sujungiamos dvi gretimos meandro juostelès.

Fig. 3.15. Surface charge distribution on meander slow-wave system in the area where adjacent strips are connected

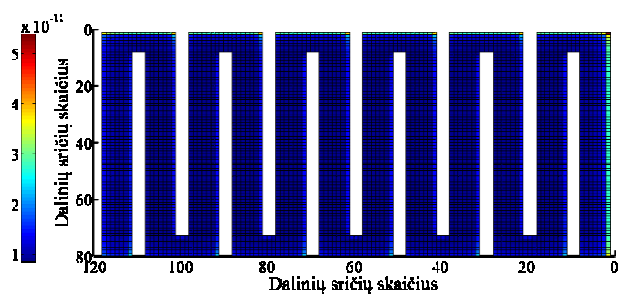

a)

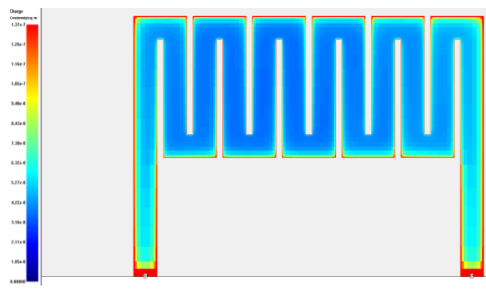

b)

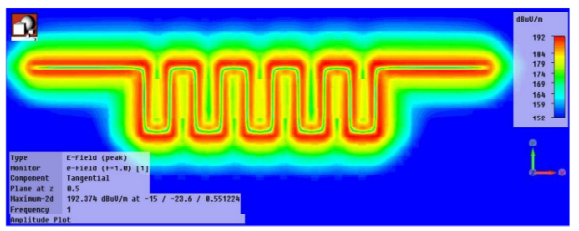

c)

3.16 pav. Elektrinio lauko pasiskirstymo meandrinèse lètinimo sistemose modeliavimas taikant: a) - siūlomą metodiką; b) - Sonnet ${ }^{\circledR}$ programų paketą; c) - darbe (Wei-Shan et al. 2009) gauti rezultatai

Fig. 3.16. Modeling of distribution of electric field in the meander slowwave system using: a) - proposed technique; b) Sonnet ${ }^{\circledR}$ software;

c) - results obtained in (Wei-Shan et al. 2009) 
3.16 paveiksle pateikiamas elektrinio lauko pasiskirstymo meandrinejje lètinimo sistemoje vaizdas iš viršaus gautas taikant siūlomą metodiką. Rezultatų palyginimui 3.16 paveiksle taip pat pateikiami krūvio tankio pasiskirstymas gautas su Sonnet ${ }^{\circledR}$ programu paketu (3.16 pav., b) ir darbe (Wei-Shan et al. 2009) gauti rezultatai (3.16 pav., c).

Vienas iš meandrinès lètinimo sistemos modeliavimo su Sonnet ${ }^{\circledR}$ programų paketų rezultatų gali būti krūvio tankio joje pasiskirstymas. Šiuo atveju (3.16 pav., b) pateikiamas krūvio tankio pasiskirstymas tokių pat konstrukcinių parametrų, kaip ir siūlomo modelio, sistemoje. Iš paveikslo matyti, kad abejose sistemose didesnis krūvis kaupiasi šoninèse meandro juostelèse. Be to, matomas ir staigus krūvio padidèjimas laidininkų kraštuose.

Darbe (Wei-Shan et al. 2009) analizuojami parametrai turintys itakos meandrinès sistemos vẻlinimo trukmei. Tyrimai atliekami esant $1 \mathrm{GHz}$ dažnio signalui. Iš pavaizduoto elektrinio lauko pasiskirstymo meandrineje lètinimo sistemoje (3.16 pav., c), matyti, kad stipresnis elektrinis laukas taip pat gaunamas juostelių kraštuose, tuo tarpu ties vidiniais kampais elektrinis laukas yra žymiai mažesnis. Nors pavaizduotoje sistemoje tarpai tarp laidininkų yra dideli $(s / h=10)$, pasiskirstymo pobūdis yra panašus ị paveiksle (3.16 pav., a) pavaizduotus rezultatus.

Taigi iš rezultatų palyginimų galima teigti, kad siūloma analizès metodika tinka elektrinio lauko meandrinèse lètinimo sistemose trimačio pasiskirstymo modeliavimui. Be to, ją galima naudoti ir uždavinių sprendimui aukštesniuose dažniuose.

\subsection{Trečiojo skyriaus išvados}

Remiantis atliktais tyrimais ir jų rezultatų analize galima padaryti šias išvadas:

1. Papildomų ekranų itterpimas didina sistemos fazinę vèlinimo trukmę žemuosiuose dažniuose ir tokiu būdu mažina jos dispersiją. Meandrinè lètinimo sistema su papildomais ekranais izžemintais iš abiejų galų pasižymi mažiausia vẻlinimo trukmès dispersija. Itterpus i sistemą papildomus ekranus, ižemintus iš abiejų galų, lètinimo sistemos vèlinimo trukmès dispersija dažnių ruože iki $1,97 \mathrm{GHz}$ sumažèja apie 3,89 karto ir neviršija $\Delta t_{\mathrm{v}}=0,035 \mathrm{~ns}$.

2. Laidininko, jungiančio gretimas meandro juosteles, pločio keitimas didina sistemos vèlinimo trukmę. Didesnis efektas pastebimas didinant jungiančio laidininko plotị. Padidinus jungiančio laidininko plotị 3 kartus, vèlinimo trukmè padidèja 1,4\% ir toks padidejimas išlieka pastovus siauresniame dažnių ruože - iki 1,72 GHz. Vèlinimo 
trukmès padidejjimas paaiškinamas talpinių netolygumų sudarymu meandriniame laidininke.

3. Tarpo didinimas sistemos kraštuose ties meandro kilpomis didina sistemos fazinę vèlinimo trukmę. Tarpo ploti padidinus 2,5 karto, fazinè vèlinimo trukmè padideja $2,7 \%$. Tuo tarpu tarpo didinimas ties meandro atviraja dalimi turi mažą efektą, todèl topologijos keitimas šios sistemos dalyje nerekomenduojamas.

4. Dèl tarpo didinimo kraštuose ties meandro kilpomis padidejusi fazinè vèlinimo trukmè žemuosiuose dažniuose gali būti sumažinta, mažinant juostelès ilgi $2 A$. Tokiu būdu, nekeičiant dispersinių savybiu sumažinamas bendras sistemos užimamas plotas. Esant meandrinio laidininko ilgiui $19 \mathrm{~mm}$, tarpo pločiui $0,5 \mathrm{~mm}$ ir tarpo ilgiui $0,6 \mathrm{~mm}$, sistemos plotas sumažeja apie $3 \%$.

5. İejjimo varža kraštuose yra pastovi dažnių ruože iki $1,5 \mathrm{GHz}$, sistemos viduryje - iki $2 \mathrm{GHz}$, o jos vertè žemuosiuose dažniuose yra tokia pati kaip ir sistemos kraštuose.

6. Ištirtas elektrinio lauko pasiskirstymas meandrinèje lètinimo sistemoje ir jos dalyje, kur sujungiamos dvi gretimos juostelès. Nustatyta, kad didesnis krūvis yra sukaupiamas šoninèse meandro juostelèse. Be to, pastebimas staigus krūvio padidejjimas laidininkų kraštuose. Toks padidèjimas parodo, kad siūloma metodika įvertina elektrinio lauko sklaidą laidžios struktūros kraštuose. 



\section{4}

\section{Meandrinių lètinimo sistemy su papildomais ekranais parametrinè sintezè}

Šiame skyriuje pasiūloma meandrinių lètinimo sistemų su papildomais ekranais ¡̇žemintais iš abiejų galų parametrinès sintezès metodika. Aptariamas apibendrintas lètinimo sistemų automatizuoto projektavimo procesas ir atliekamas meandrinių lètinimo sistemų su papildomais ekranais elektrinių charakteristiku jautrumo jos konstrukcinių parametrų keitimui įvertinimas nustatant įtakos koeficientus.

İvertinus konstrukcinių parametrų ịtaką lètinimo sistemos elektrinèms charakteristikoms, sudaromas meandrinių lètinimo sistemų su papildomais ekranais j̇žemintais iš abiejų galų parametrinès sintezès algoritmas, kuris patikrinamas atliekant keturių lètinimo sistemų sintezę.

Skyriuje pateikta medžiaga buvo pristatyta šešioliktoje respublikinèje Lietuvos jaunujų mokslininkų konferencijoje „Mokslas - Lietuvos ateitis“. 


\subsection{Specializuotų programų paketų taikymo meandrinių lètinimo sistemų parametrinei sintezei galimybių analizè}

Šiuolaikiniai mikrobangų įtaisai, tarp jų ir lètinimo sistemos, projektuojami taikant automatizuoto projektavimo kompiuterizuotas sistemas, kurias valdo specializuoti programų paketai.

Monografijoje (Štaras et al. 2010) teigiama, kad mikrobangų įtaisu projektavimas vykdomas keliais etapais - tai konstrukcijos pradinio varianto analize ir sintezé; pradinio varianto koregavimas ir jei reikia, naujojo varianto analizé; konstrukcijos optimizavimas; projektinès dokumentacijos rengimas.

Pažymètina, kad automatinès sintezès ir optimizavimo algoritmai automatizuoto projektavimo sistemose igyvendinami panašiais būdais. Ir sintezès, ir optimizavimo ciklą sudaro analizè, gautų charakteristikų palyginimas su reikalingomis bei ịtaiso konstrukcijos parametrų keitimo procedūros.

Apibendrintoji automatizuoto lètinimo sistemų projektavimo proceso schema pateikta 4.1 paveiksle. Pirmuoju projektavimo etapu (1-4 blokai) projektuotojas, pritaikydamas savo patirtị ir sintezès metodus, sintezuoja pradinị lètinimo sistemos variantą. Sintezei taikomi pradinę konstrukciją atitinkantis matematinis lètinimo sistemos modelis ir techniniais reikalavimais pagristi pradiniai duomenys.

Šiame skyriuje plačiau aptariamas antrasis projektavimo etapas (5-6 blokai), kuriame analizuojamas lètinimo sistemos modelis. Šiam tikslui gali būti taikomi programų paketai, pagrịsti matematiniais modeliais, sukurtais lètinimo sistemų savybèms tirti. Mūsų atveju tai Sonnet ${ }^{\circledR}$ programų pakete esantis variklis em ${ }^{\circledR}$, skirtas aukštadažnių planariujų grandynų analizei momentų metodu. Analizès metu apskaičiuotos charakteristikos lyginamos su techniniais reikalavimais. Jeigu palyginimo rezultatai yra nepatenkinami, modelio parametrai keičiami ir vèl kartojama analizès procedūra.

Trečiuoju projektavimo etapu gaminamas projektuojamos létinimo sistemos bandomasis maketas ir matuojamos jo charakteristikos (7 blokas). Ištyrus bandomaji sistemos maketą rengiama konstrukcijos technologine dokumentacija (8 blokas) ir gaminama suprojektuotoji lètinimo sistema.

Reikètu atkreipti dèmesi i 4.1 paveiksle pateikto algoritmo 9 ir 10 blokus. Analizès metu apskaičiuotos charakteristikos lyginamos su techniniais reikalavimais. Jeigu palyginimo rezultatai yra nepatenkinami, modelio parametrai keičiami ir vèl kartojama analizès procedūra. Tokių būdų vykdoma sistemos parametriné sintezè ir optimizavimas. Optimizavimo procesui palengvinti, prieš nustatant pakeitimus, gali būti analizuojamas lètinimo sistemos parametru jautrumas keitimams. Jautrumo analizei taikomi tie patys matematiniai modeliai. 
Sekančiame poskyryje aptarsime meandrinių lètinimo sistemų su papildomais ekranais elektrinių charakteristikų jautrumą jos konstrukcinių parametrų keitimui.

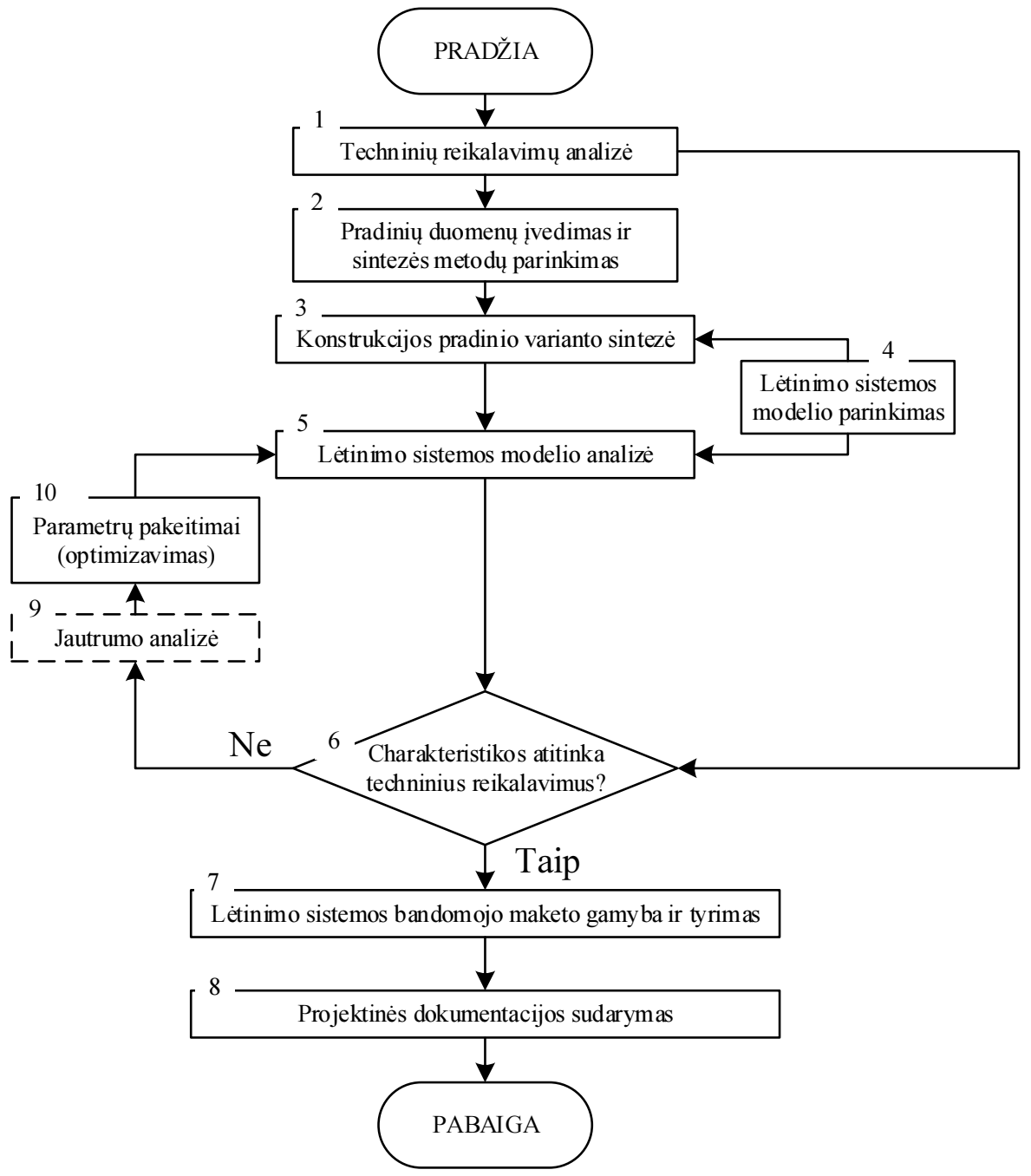

4.1 pav. Apibendrintoji lètinimo sistemų automatizuoto projektavimo proceso schema (Štaras et al. 2010)

Fig. 4.1. The block diagram illustrating the process of computer aided design of slow-wave system (Štaras et al. 2010) 


\subsection{Meandrinių létinimo sistemụ su papildomais ekranais konstrukciniu parametru itakos koeficientai}

Meandrinių lètinimo sistemų su papildomais ekranais parametriné sintezè - tai automatizuoto projektavimo proceso dalis, kurios metu siekiant gauti reikiamas itaiso išejimo elektrines charakteristikas keičiami jo konstrukciniai parametrai.

Pagrindinès lètinimo sistemos elektrinès charakteristikos yra tokios: praleidžiamujjų dažnių juostos plotis $\Delta F$, vélinimo trukmé $t_{\mathrm{v}}$, ir banginè varža $Z_{\mathrm{B}}$. Apskritai šios charakteristikos (išskyrus $\Delta F$ ) nustatomos arba apskaičiuojamos žemujų dažnių srityje. Monografijoje (Štaras et al. 2010) teigiama, kad meandrinių lètinimo sistemu vienalyčiame dielektrike bangine $Z_{\mathrm{B}}$ ir iejjimo $Z_{\mathrm{IN}}$ varžos sutampa, o nevienalyčiame dielektrike skiriasi labai nedaug. Todèl toliau skyriuje bus naudojama įejjimo varžos $Z_{\mathrm{IN}}$ sąvoka.

Pagrindiniai meandrinès lètinimo sistemos su papildomais ekranais konstrukciniai parametrai yra tokie: dielektrinio pagrindo storis $h$ ir santykine dielektrinè skvarba $\varepsilon_{\mathrm{r}}$, vienos meandro laidininko juostelès ilgis $2 A$ ir jos plotis $w_{1}$, papildomo ekrano plotis $w_{2}$ ir tarpo tarp gretimu juosteliu plotis $s$.

Konstrukciniu parametru itaka sistemos elektrinès charakteristikoms yra nevienoda. Todèl, norint pasiekti optimalius sintezès rezultatus, būtina ištirti pagrindinių meandrinès lètinimo sistemos su papildomais ekranais konstrukcinių parametru itaką jos elektrinèms charakteristikoms. Tyrimo rezultatai leis patobulinti tokių sistemų sintezès algoritmus.

Tyrimams buvo panaudota meandrinès lètinimo sistemos su papildomais ekranais įžemintais iš abiejų galų konstrukcija, kurios topologijos fragmentas ir trimatis vaizdas pateikti 4.2 paveiksle. Tiriamos sistemos pradiniai matmenys yra tokie: $2 A=20 \mathrm{~mm} ; w_{1}=0,5 \mathrm{~mm} ; w_{2}=0,25 \mathrm{~mm} ; s=0,65 \mathrm{~mm} ; \varepsilon_{\mathrm{r}}=7,3$; $h=0,5 \mathrm{~mm}$.

İvertinti meandrinių lètinimo sistemų su papildomais ekranais konstrukcinių parametrų įtaka jos vélinimo trukmei, iejjimo varžai ir praleidžiamujų dažnių juostos pločiui galima nustatant itakos koeficientus. Tam tikro konstrukcinio parametro įtakos koeficientas gali būti išreikštas formule

$$
S=\left(\frac{\Delta p}{p_{0}}\right) /\left(\frac{\Delta d}{d}\right),
$$

čia $\Delta p$ - lètinimo sistemos elektrinès charakteristikos pokytis; $p_{0}$ - lètinimo sistemos su pradiniais konstrukciniais parametrais elektrinès charakteristikos verté; $\Delta d$ - pasirinkto konstrukcinio parametro pokytis; $d$ - pradine konstrukcinio parametro vertè. 


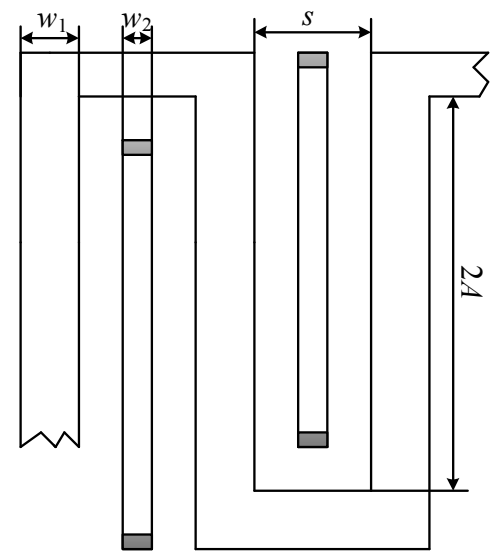

a)

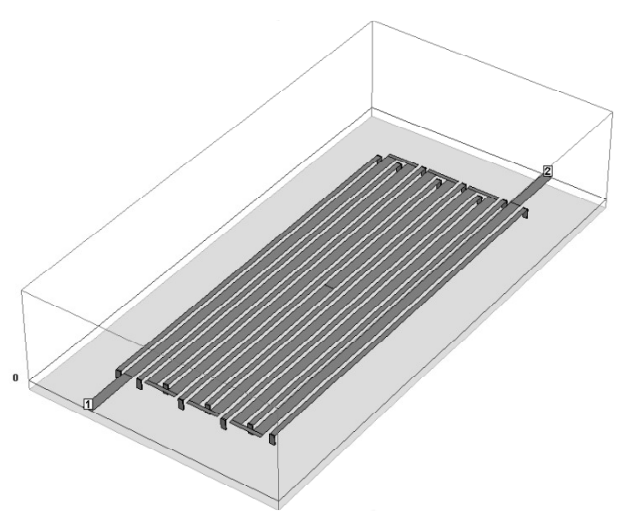

b)

4.2 pav. Meandrinès lètinimo sistemos su papildomais ekranais įžemintais iš abiejų galų: a) topologijos fragmentas; b) trimatis vaizdas

Fig. 4.2. Meander slow-wave system with additional shields grounded at both edges: a) topology fragment; b) 3D view

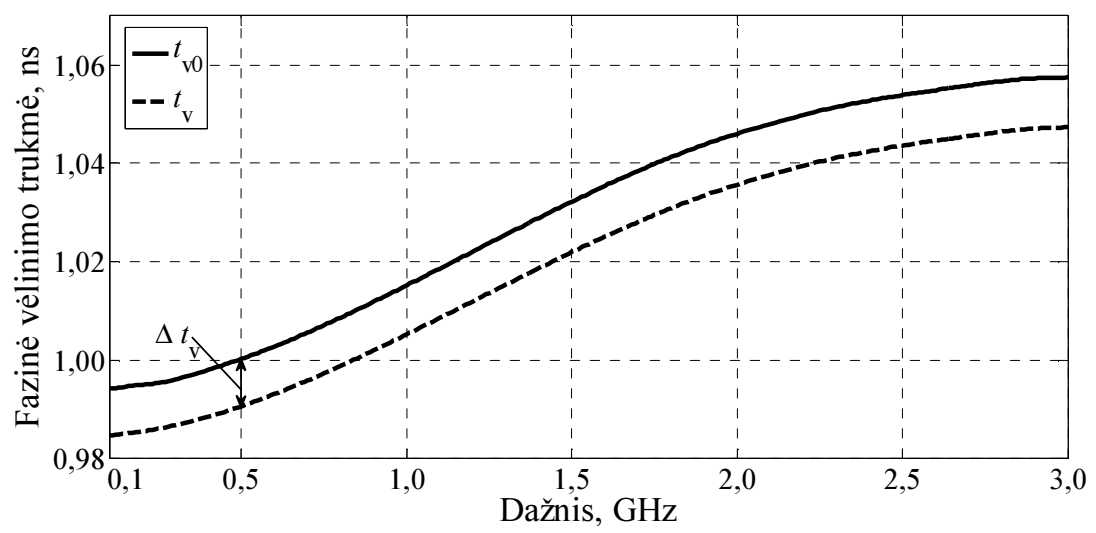

4.3 pav. Fazinès vèlinimo trukmès pokytis, sumažinus meandro formos laidininko juostelès ilgị $2 A$ vienu procentu

Fig. 4.3. Change in phase delay time when a length of a meander conductor is changed by one percent

Tyrimų metu, nustatant įtakos koeficientus, konstrukciniai parametrai buvo mažinami $1 \%$. Pavyzdžiui, fazinès vèlinimo trukmès pokytis, sumažinus 
meandro formos laidininko juostelès ilgi $2 A$ nuo $20 \mathrm{~mm}$ iki $19,8 \mathrm{~mm}$, pavaizduotas 4.3 paveiksle.

Iš 4.3 paveiksle pateikto grafiko matyti, kad sumažinus juostelès ilgi $2 A$ vienu procentu, sistemos fazinès vèlinimo trukmès vertè sumažejja. Tokiu būdu, nustačius fazinès vèlinimo trukmès pokytị žemuosiuose dažniuose $\Delta t_{\mathrm{v}}$, galima apskaičiuoti konstrukcinio parametro $2 A$ ịtakos koeficientą pagal 4.1 išraišką. Sekančiuose skyreliuose pateiksime meandrinių lètinimo sistemų su papildomais ekranais įžemintais iš abiejų galų konstrukcinių parametrų įtakos koeficientus ir ivertinsime sistemos fazinès vèlinimo trukmès, iejimo varžos ir praleidžiamujų dažnių juostos pločio jautrumą konstrukcinių parametrų keitimui.

\subsubsection{Konstrukcinių parametru ịtaka sistemos fazinei vèlinimo trukmei}

Meandrinès lètinimo sistemos su papildomais ekranais įžemintais iš abiejų galų fazinès vèlinimo trukmès jautrumo laidininko ilgio $2 A$ ir jo pločio $w_{1}$ pokyčiams tyrimo rezultatai yra pateikti 4.4 paveiksle.

a)

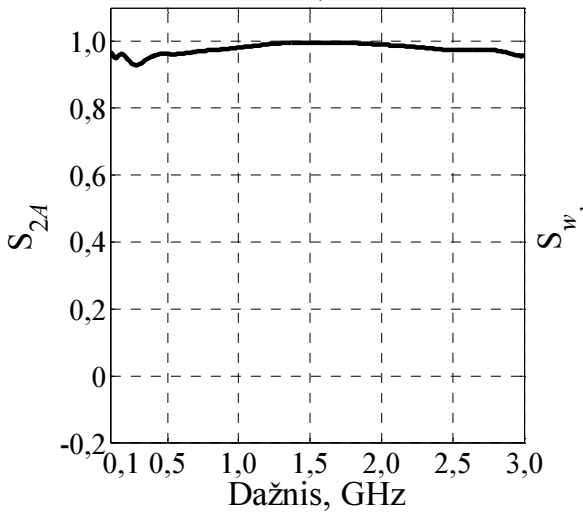

b)

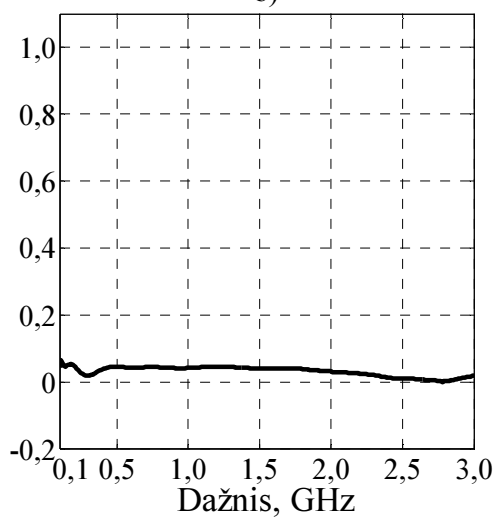

4.4 pav. İtakos, sistemos fazinei vėlinimo trukmei, koeficientai keičiant:

a) meandro laidininko ilgi $2 A$; b) meandro laidininko ploti $w_{1}$

Fig. 4.4. Impact coefficients on phase delay time of a system when changing: a) a length of meander conductor $2 A$; b) a width of meander conductor $w_{1}$

Čia pavaizduotos įtakos koeficientų vertès kintant dažniui, kai laidininko ilgis $2 A$ (4.4 pav., a) ir plotis $w_{1}$ (4.4 pav., b) mažinami vienu procentu. Iš grafikuose pateiktų kreivių matyti, kad sumažinus laidininko ilgị $2 A$ vienu procentu, sistemos fazinès vèlinimo trukmès vertè irgi sumažèja apie $1 \%$. Daug mažesnę 
itaką sistemos fazinei vèlinimo trukmei turi meandro laidininko pločio keitimas. Šiuo atveju, sumažèjus pločiui $w_{1}$ vienu procentu, fazinès vèlinimo trukmès vertè sumažeja vos $0,06 \%$.

4.5 paveiksle pateikiamos įtakos koeficientų vertès kintant dažniui, kai vienu procentu mažinamas tarpo tarp gretimų meandro laidininko juosteliu plotis $s$ (4.5 pav., a) ir papildomo ekrano plotis $w_{2}$ (4.5 pav., b). Iš grafikų matyti, kad sumažejus tarpui tarp gretimų meandro juostelių vienu procentu, fazinès vèlinimo trukmès vertė žemuosiuose dažniuose sumažèja apie $0,07 \%$. Tuo tarpu papildomo ekrano pločio $w_{2}$ keitimas įtakos fazinei vélinimo trukmei beveik neturi. Šiuo atveju įtakos koeficiento verte žemuosiuose dažniuose yra arti nulio.
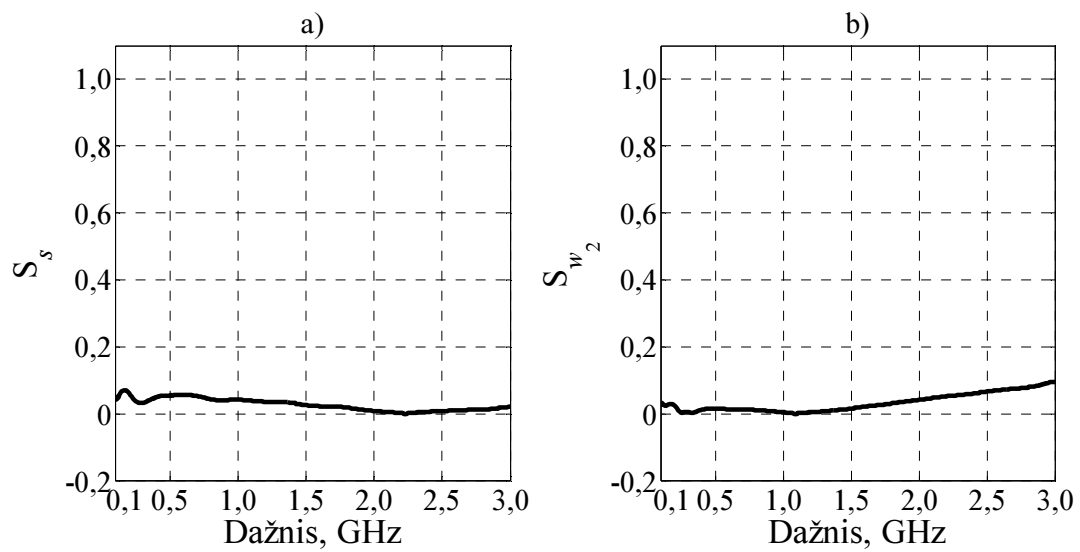

4.5 pav. a) İtakos, sistemos fazinei vèlinimo trukmei, koeficientai keičiant:

a) tarpo tarp gretimų meandro juostelių plotị $s$; b) papildomo ekrano plotị $w_{2}$

Fig. 4.5. Impact coefficients on phase delay time of a system when changing: a) a gap between adjacent meander conductors $s$; b) width of additional shield $w_{2}$

Meandrinès lètinimo sistemos su papildomais ekranais fazinès vèlinimo trukmès jautrumo, keičiant dielektrinio pagrindo parametrus, tyrimo rezultatai pateikiami 4.6 paveiksle. Čia parodyti santykinès dielektrinès skvarbos $\varepsilon_{\mathrm{r}}$ (4.6 pav., a) ir dielektrinio pagrindo storio $h$ (4.6 pav., b) įtakos koeficientai.

Iš pateiktu grafikų matyti, kad didesnę itaką sistemos fazinei vèlinimo trukmei turi santykinès dielektrinès skvarbos keitimas. Sumažinus $\varepsilon_{\mathrm{r}}$ vienu procentu, fazinè vèlinimo trukmè sumažeja apie $0,5 \%$. Tuo tarpu dielektrinio pagrindo storio $h$ įtakos koeficientas yra neigiamas. Tai reiškia, kad sumažejjus sto- 
riui $h$ vienu procentu, sistemos fazinès vèlinimo trukmès vertè padideja apie $0,1 \%$.

a)

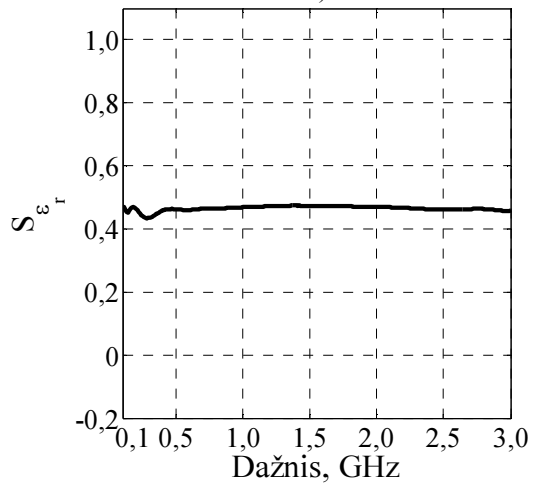

b)

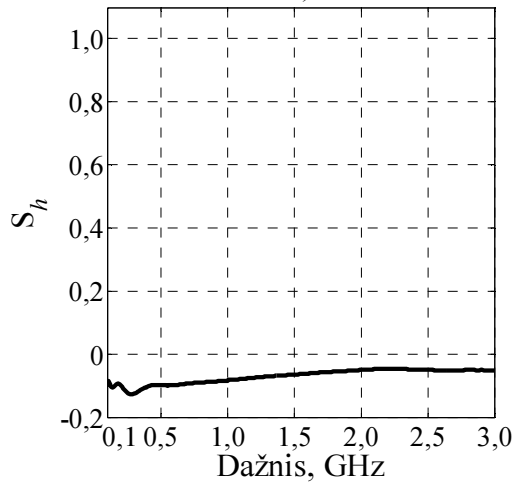

4.6 pav. Itakos, sistemos fazinei vèlinimo trukmei, koeficientai keičiant: a) dielektrinio pagrindo santykinę dielektrinę skvarbą $\varepsilon_{\mathrm{r}}$; b) dielektrinio pagrindo stori $h$

Fig. 4.6. Impact coefficients on phase delay time of a system when changing: a) a relative permittivity $\varepsilon_{\mathrm{r}}$; b) height of a dielectric substrate $h$

Apibendrinant rezultatus galima teigti, kad didžiausia įtaką meandrinès lètinimo sistemos su papildomais ekranais įžemintais iš abiejų galų fazinei vèlinimo trukmei turi laidininko ilgio $2 A$ keitimas. Mažesnè įtaka pastebima keičiant dielektrinio pagrindo parametrus: santykinę dielektrinę skvarbą $\varepsilon_{\mathrm{r}}$ ir stori $h$. Keičiant kitus konstrukcinius parametrus, tokius kaip meandro laidininko plotis $w_{1}$, papildomo ekrano plotis $w_{2}$ ir tarpo tarp gretimu meandro juosteliu plotis $s$, sistemos fazinè vèlinimo trukmé beveik nesikeičia. Taigi norint pakeisti lètinimo sistemos fazinę vėlinimo trukmę, reikia keisti meandro laidininko ilgi $2 A$ arba ju skaičių, o taip pat dielektrinio pagrindo medžiagą.

\subsubsection{Konstrukcinių parametrų ịtaka sistemos jejjimo varžai}

Meandrinès lètinimo sistemos su papildomais ekranais įžemintais iš abiejų galų iejjimo varžos jautrumo, laidininko ilgio $2 A$ ir jo pločio $w_{1}$ pokyčiams, tyrimo rezultatai yra pateikti 4.7 paveiksle.

Čia pavaizduotos įtakos koeficientų vertès kintant dažniui, kai laidininko ilgis $2 A$ (4.7 pav., a) ir plotis $w_{1}(4.7$ pav., b) mažinami vienu procentu. Iš grafikuose pateiktų kreivių matyti, kad sumažinus laidininko ilgi $2 A$ vienu procentu, itakos koeficientas yra arti nulio, t.y. sistemos iejjimo varžos vertè beveik nesi- 
keičia. Didesnę įtaką sistemos įejjimo varžai turi meandro laidininko pločio keitimas. Šiuo atveju, sumažejus pločiui $w_{1}$ vienu procentu, iejjimo varžos vertè žemuosiuose dažniuose sumažejja 0,3 \%. Taip pat reikètų atkreipti dèmesį i tai, kad

a)

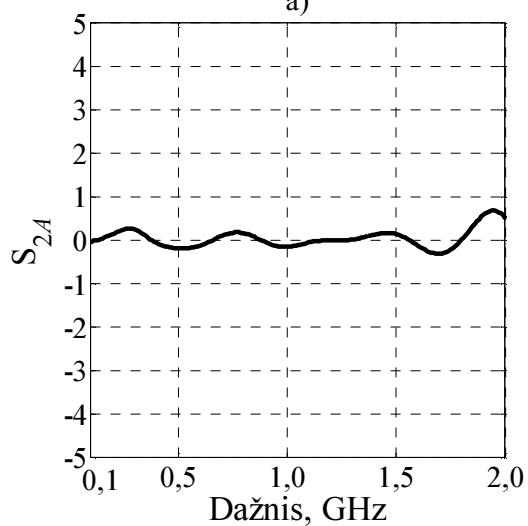

b)

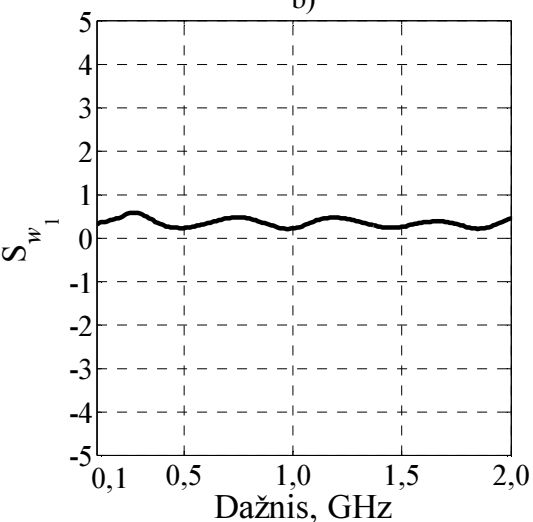

4.7 pav. İtakos, sistemos iejjimo varžai, koeficientai keičiant: a) meandro laidininko ilgị $2 A$; b) meandro laidininko ploti $w_{1}$

Fig. 4.7. Impact coefficients on input impedance of a system when changing: a) a length of meander conductor $2 A$; b) a width of meander conductor $w_{1}$

a)

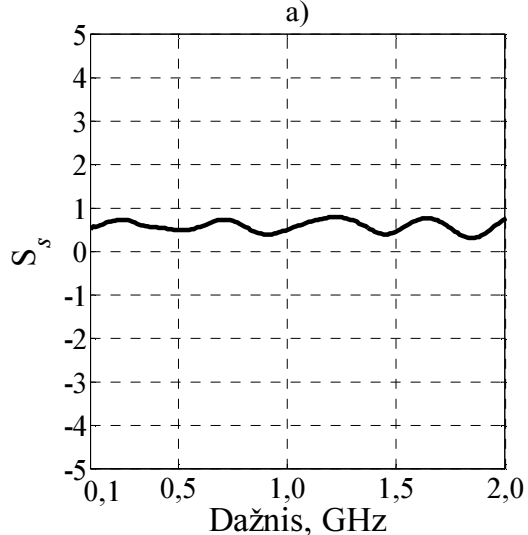

b)

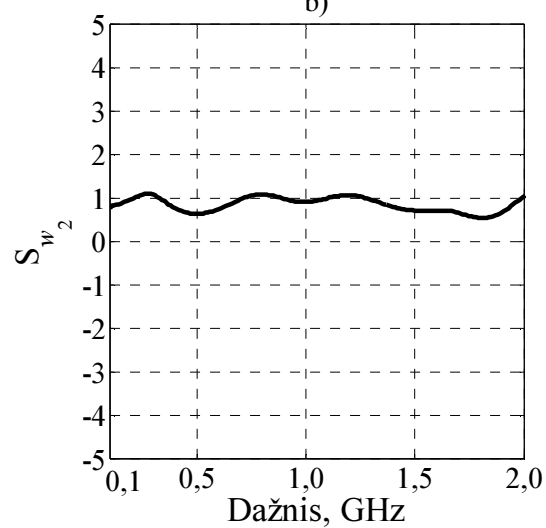

4.8 pav. İtakos, sistemos įejjimo varžai, koeficientai keičiant: a) tarpo tarp gretimų meandro juostelių plotị $s ;$ b) papildomo ekrano plotị $w_{2}$

Fig. 4.8. Impact coefficients on input impedance of a system when changing: a) a gap between adjacent meander conductors $s$; b) width of additional shield $w_{2}$ 
aukštesniuosiuose dažniuose pastebimi kreivių svyravimai, kurie atsiranda dèl ièjimo varžos nesuderinamumo su generatoriaus apkrova didèjant dažniui.

4.8 paveiksle pateikiamos įtakos koeficientų vertès kintant dažniui, kai vienu procentu mažinamas tarpo tarp gretimų meandro laidininko juostelių plotis $s$ (4.8 pav., a) ir papildomo ekrano plotis $w_{2}$ (4.8 pav., b). Iš grafiku matyti, kad sumažèjus tarpui tarp gretimu meandro juostelių vienu procentu, iejjimo varžos verte žemuosiuose dažniuose sumažeja apie 0,5 \%. Tuo tarpu papildomo ekrano pločio $w_{2}$ keitimas turi didesnę itaką sistemos iejjimo varžai. Siuo atveju įtakos koeficiento verte žemuosiuose dažniuose yra arti vieneto, todèl sumažinus $w_{2}$ vienu procentu, sistemos įejjimo varža taip pat sumažèja apie $1 \%$.

Meandrinès lètinimo sistemos su papildomais ekranais iejjimo varžos jautrumo, keičiant dielektrinio pagrindo parametrus, tyrimo rezultatai pateikiami 4.9 paveiksle. Čia parodyti santykinès dielektrinès skvarbos $\varepsilon_{\mathrm{r}}(4.9$ pav., a) ir dielektrinio pagrindo storio $h(4.9$ pav., b) įtakos koeficientai.

a)

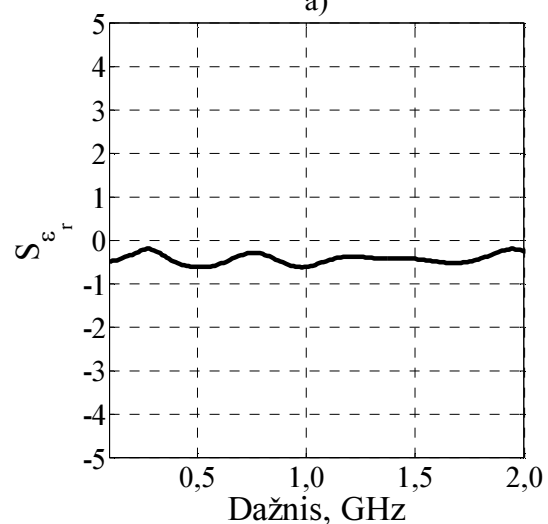

b)

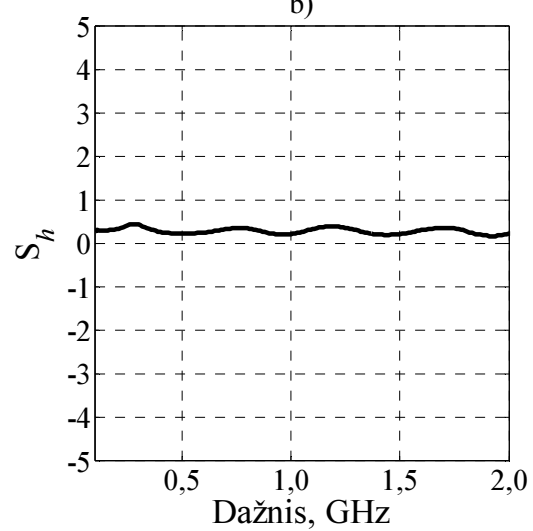

4.9 pav. Itakos, sistemos ịejimo varžai, koeficientai keičiant: a) dielektrinio pagrindo santykinę dielektrinę skvarbą $\varepsilon_{\mathrm{r}}$; b) dielektrinio pagrindo storị $h$

Fig. 4.9. Impact coefficients on input impedance of a system when changing: a) a relative permittivity $\varepsilon_{\mathrm{r}}$; b) height of a dielectric substrate $h$

Iš pateiktų grafikų matyti, kad didesnę įtaką sistemos įejjimo varžai turi santykinès dielektrinès skvarbos keitimas. Sumažinus $\varepsilon_{\mathrm{r}}$ vienu procentu, įtakos koeficientas $S_{\text {er }}$ igyja neigiamą vertę, o sistemos iejjimo varža padidèja apie $0,5 \%$. Tuo tarpu dielektrinio pagrindo storio $h$ įtakos koeficientas yra teigiamas. Tai reiškia, kad sumažejus storiui $h$ vienu procentu, sistemos iejjimo varžos vertè sumažèja apie $0,2 \%$. 
Apibendrinant rezultatus galima teigti, kad didžiausia įtaką meandrinès lètinimo sistemos su papildomais ekranais izžemintais iš abiejų galų įejjimo varžai turi papildomo ekrano pločio $w_{2}$ keitimas. Mažesnè įtaka pastebima keičiant tarpo tarp gretimų meandro juostelių plotị $s$ ir pagrindo santykinę dielektrinę skvarbą $\varepsilon_{\mathrm{r}}$. Kitų konstrukcinių parametrų, tokių kaip dielektrinio pagrindo storis $h$ ir meandro laidininko plotis $w_{1}$, itakos koeficientai yra dar mažesni ir siekia $0,2-0,3$. Tuo tarpu meandro laidininko ilgio $2 A$ keitimas sistemos iejjimo varžos žemuosiuose dažniuose nekeičia. Be to reikètų pastebèti, kad kintant dažniui, iejjimo varžos įtakos koeficientų kreivèse pastebimi svyravimai. Kaip buvo minèta 3.3 poskyryje, svyravimus nulemia sistemos kraštų, kuriuose pakinta iejjimo varžos dydis ir atsiranda signalų trakto nesuderinamumas.

\subsubsection{Konstrukcinių parametrų ịtaka sistemos praleidžiamujjų dažnių juostos pločiui}

4.2.1 ir 4.2.2 skyreliuose pateiktu konstrukciniu parametru įtakos koeficientų meandrinių lètinimo sistemų su papildomais ekranais izžemintais iš abiejų galų fazinei vèlinimo trukmei ir iejjimo varžai tyrimo rezultatai apibendrinti 4.1 lentelèje. Čia taip pat parodytas sistemos praleidžiamųư dažnių juostos pločio jautrumas konstrukcinių parametrų keitimui išreikštas per įtakos koeficientus.

4.1 lentelè. Meandrinių lètinimo sistemų su papildomais ekranais ižemintais iš abiejų galų konstrukcinių parametrų įtaka jos elektrinèms charakteristikoms

Table 4.1. Influence of constructive parameters of meander slow-wave system with additional shields grounded at both edges on it's electrical parameters

\begin{tabular}{|c|c|c|c|}
\hline \multirow{2}{*}{ Konstrukcijos ir topologijos parametrai } & \multicolumn{3}{|c|}{$\begin{array}{c}\text { Itakos koeficientai, mažèjant } \\
\text { atitinkamam konstrukcijos } \\
\text { parametrui 1\% }\end{array}$} \\
\cline { 2 - 4 } & $Z_{\mathrm{IN}}$ & $t_{\mathrm{v}}$ & $\Delta F$ \\
\hline Meandro laidininko ilgis $2 A$ & 0 & 1 & $-1,36$ \\
\hline Meandro laidininko plotis $w_{1}$ & 0,3 & 0,06 & $-0,68$ \\
\hline Papildomo ekrano plotis $w_{2}$ & 1 & 0 & 0 \\
\hline Tarpo tarp gretimu meandro laidininku plotis $s$ & 0,5 & 0,07 & $-0,68$ \\
\hline Pagrindo santykinè dielektrinè skvarba $\varepsilon_{\mathrm{r}}$ & $-0,5$ & 0,5 & $-1,36$ \\
\hline Dielektrinio pagrindo storis $h$ & 0,2 & $-0,1$ & $-0,68$ \\
\hline
\end{tabular}


Iš 4.1 lentelès matyti, kad didžiausią ịtaką sistemos praleidžiamuju dažnių juostos pločiui turi meandro laidininko ilgio $2 A$ ir pagrindo santykinès dielektrinès skvarbos $\varepsilon_{\mathrm{r}}$ keitimas. Sumažinus šiuos didžius $1 \%, \Delta F$ padidèja apie $1,36 \%$. Nemažą įtaką praleidžiamujų dažnių juostos pločiui turi ir meandro laidininko pločio $w_{1}$, tarpo tarp gretimų meandro laidininko pločio $s$ ir dielektrinio pagrindo storio $h$ pokyčiai. Sumažinus šiuos dydžius $1 \%, \Delta F$ padideja $0,68 \%$. Papildomo ekrano pločio $w_{2}$ keitimas, itakos sistemos praleidžiamujų dažnių juostos pločiui neturi.

Apibendrinant galima teigti, kad tam tikras meandrinès lètinimo sistemos su papildomais ekranais įžemintais iš abiejų galų elektrinis parametras priklauso nuo kelių konstrukcinių parametrų. Pavyzdžiui, reikiamas įejjimo varžos $Z_{\mathrm{IN}}$ vertes galima gauti keičiant tarpo tarp gretimų meandro laidininkų plotị $s$, pagrindo santykinę dielektrinę skvarbą $\varepsilon_{\mathrm{r}}$ arba meandro laidininko plotị $w_{1}$. Reikiama vèlinimo trukmès vertę galima gauti keičiant meandro laidininko ilgi $2 \mathrm{~A}$ arba dielektrinio pagrindo parametrus $\varepsilon_{\mathrm{r}}$ ir $h$.

Tačiau ne visi šie parametrai keistini. Kai kurių konstrukcinių parametrų keitimą riboja pasirinkta gamybos technologija, todèl jie negali būti laisvai varijuojami. Tokie parametrai yra dielektrinio pagrindo storis $h$ ir jo santykine dielektriné skvarba $\varepsilon_{\mathrm{r}}$. Tai įvertinus, varijuojamų konstrukcijos parametrų skaičius sumažèja, o sintezès procesas tampa paprastesnis. Taigi pagrindiniai sintezès metų varijuojami parametrai yra šie: meandro laidininko ilgis $2 A$ ir jo plotis $w_{1}$, papildomo ekrano plotis $w_{2}$ ir tarpo tarp gretimų meandro juosteliu plotis $s$.

Kai konstrukcijos parametrų įtaka sistemoms elektrinėms charakteristikoms yra žinoma, gali būti sudarytas meandrinių lètinimo sistemų su papildomais ekranais įžemintais iš abiejų galų sintezès algoritmas.

\subsection{Meandrinių létinimo sistemụ su papildomais ekranais parametrinès sintezès algoritmas}

Ivertinus 4.2.1-4.2.3 skyreliuose pateiktus duomenis buvo sudarytas meandrinių lètinimo sistemų su papildomais ekranais įžemintais iš abiejų galų sintezès algoritmas.

Parametrinè sintezè, kurios algoritmas pavaizduotas 4.10 paveiksle, pradedama reikiamų elektrinių charakteristikų - praleidžiamujų dažnių juostos pločio $\Delta F_{\text {reik }}$, fazinès vèlinimo trukmès $t_{\text {vreik }}$ ir iejjimo varžos $Z_{\text {INreik }}$ ịvedimu (1 blokas). Toliau projektuotojas, naudodamasis savo patirtimi parenka pradinius sistemos konstrukcinius parametrus (2 blokas) ir susintezuoja pradinị meandrinès lètinimo sistemos konstrukcijos variantą. Tai daroma iteraciniu būdu, MATLAB ${ }^{\mathrm{TM}}$ terpe valdant kompiuterizuotą projektavimo sistemą. Be to, šiame sintezès etape galima keisti tuos konstrukcinius parametrus, kurių keitimas tolimesniuose etapuose 
nėra numatytas - tai meandro laidininkų skaičius $N$, pagrindo santykinè dielektrinè skvarba $\varepsilon_{\mathrm{r}}$ ir jo storis $h$. Ivedus pradinius sistemos konstrukcinius parametrus, naudojant instrumentinių priemonių komplektą (angl. toolbox) SonnetLab nubraižomas pradinis lètinimo sistemos variantas, kuris vèliau analizuojamas Sonnet $^{\circledR}$ programų pakete esančiu varikliu em ${ }^{\circledR}$, skirtu aukštadažnių planariujų grandynų analizei momentų metodu.

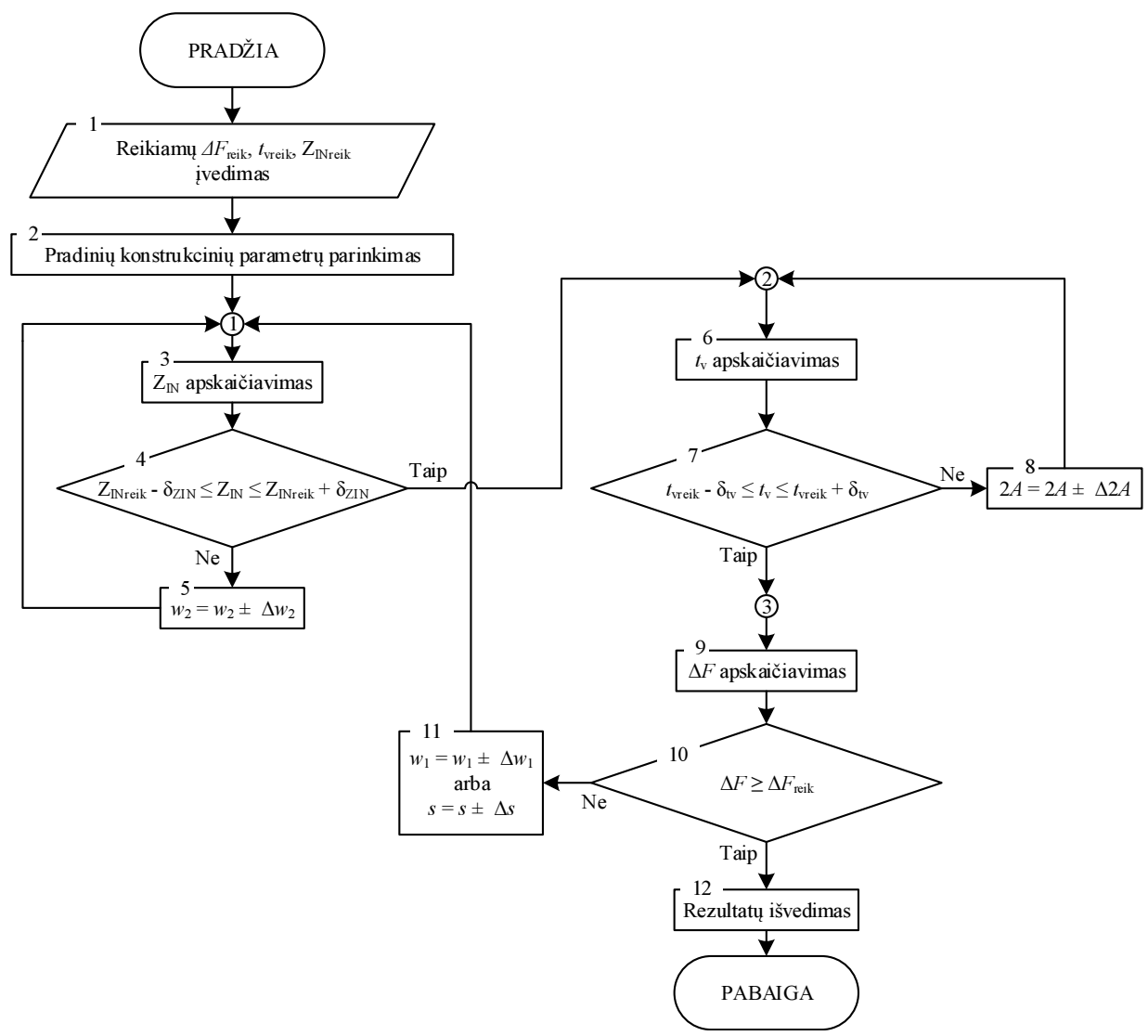

4.10 pav. Meandrinių lètinimo sistemų su papildomais ekranais įžemintais iš abiejų galų parametrinès sintezės algoritmas

Fig. 4.10. Algorithm for synthesis of a meander slow-wave system with additional shields grounded at both edges

Parinkus pradines konstrukcinių parametrų vertes prasideda automatinès sintezès procesas, kuri sudaro tris ciklai. Kiekvieno ciklo metu konstrukcinis parametras, turintis didžiausią įtaką vienai iš elektrinių charakteristikų, keičia- 
mas tol, kol bus gauta reikiama šios elektrinès charakteristikos vertė žemujų dažnių srityje. Šio proceso metu kitų konstrukcinių parametrų vertès yra fiksuotos.

Pirmuoju ciklu (3-5 blokai) papildomo ekrano plotis $w_{2}$ keičiamas tol, kol gaunama reikiama iejjimo varžos žemuosiuose dažniuose verte $Z_{\mathrm{IN}}$. Antruoju ciklu (6-8 blokai) meandro laidininko ilgis $2 A$ keičiamas tol, kol gaunama reikiama vèlinimo trukmès žemujų dažnių srityje $t_{\mathrm{v}}$ vertè. Trečiuoju ciklu (10 ir 11 blokai) gali būti keičiami meandro laidininko plotis $w_{1}$ arba tarpo tarp gretimų meandro juostelių plotis $s$, kurie lemia sistemos praleidžiamujjų dažnių juostos ploti $\Delta F$. Tačiau kintant šiems konstrukciniams parametrams keičiasi sistemos iejjimo varža $Z_{\mathrm{IN}}$ ir vélinimo trukmé $t_{\mathrm{v}}$, todèl po trečiojo ciklo grịžtama $i$ pirmaji.

Sintezès algoritmo patikros rezultatai apibendrinti 4.2 lentelejje. Čia pateikiamos keturių meandrinių lètinimo sistemų su papildomais ekranais įžemintais iš abiejų galų elektrinès charakteristikos ir sintezuoti šių sistemų konstrukciniai parametrai. Sintezès metu buvo naudojami du skirtingi dielektriniai pagrindai kompanijos Rogers Corporation RO3006 ${ }^{\mathrm{TM}}$ medžiaga, kurios santykiné dielektrinè skvarba $\varepsilon_{\mathrm{r}}=6,15$ ir plačiai spausdintiniu plokščiu gamyboje naudojama FR4 medžiaga, kurios $\varepsilon_{\mathrm{r}}=4,4$.

4.2 lentelè. Meandrinių lètinimo sistemų su papildomais ekranais ižemintais iš abiejų galu elektrinès charakteristikos ir sintezuoti konstrukciniai parametrai

Table 4.2. Electrical properties and constructive parameters of synthesized meander slow-wave system with additional shields grounded at both edges

\begin{tabular}{|c|c|c|c|c|c|c|c|c|c|c|}
\hline 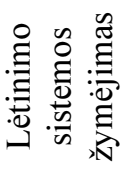 & $\begin{array}{l}\stackrel{a}{\leftrightarrows} \\
\stackrel{3}{3}\end{array}$ & $\begin{array}{l}\mathbf{C} \\
\hat{z} \\
\hat{N}\end{array}$ & 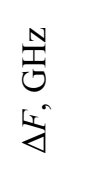 & $\begin{array}{l}\Xi \\
\Xi \\
\Xi\end{array}$ & $\omega$ & $\begin{array}{l}\Xi \\
\Xi \\
\Xi\end{array}$ & $\begin{array}{l}\Xi \\
\Xi \\
\hat{I}\end{array}$ & $\begin{array}{l}\Xi \\
\Xi \\
\tilde{\Xi}\end{array}$ & $\begin{array}{l}\Xi \\
\Xi \\
\overrightarrow{\mathbb{d}}\end{array}$ & $z$ \\
\hline LS1 & 1 & 50 & 2,72 & 0,13 & 6,15 & 0,22 & 0,47 & 0,9 & 25 & 5 \\
\hline LS2 & 1 & 75 & 2,72 & 0,25 & 6,15 & 0,18 & 0,8 & 0,9 & 25 & 5 \\
\hline LS3 & 3 & 50 & 1,82 & 0,13 & 6,15 & 0,22 & 0,4 & 0,9 & 25,5 & 15 \\
\hline LS4 & 1 & 50 & 2,67 & 0,3 & 4,4 & 0,62 & 0,85 & 0,42 & 29,4 & 5 \\
\hline
\end{tabular}

Iš 4.2 lentelëje pateiktų duomenų matyti, kad didesnè iejjimo varža, nekintant vèlinimo trukmei $t_{\mathrm{v}}$ ir praleidžiamujjų dažnių juostos pločiui $\Delta F$, gaunama padidinus dielektrinio pagrindo storị $h$ ir papildomo ekrano plotị $w_{2}$ bei sumažinus meandro laidininko ploti $w_{1}$ (LS1 ir LS2). 

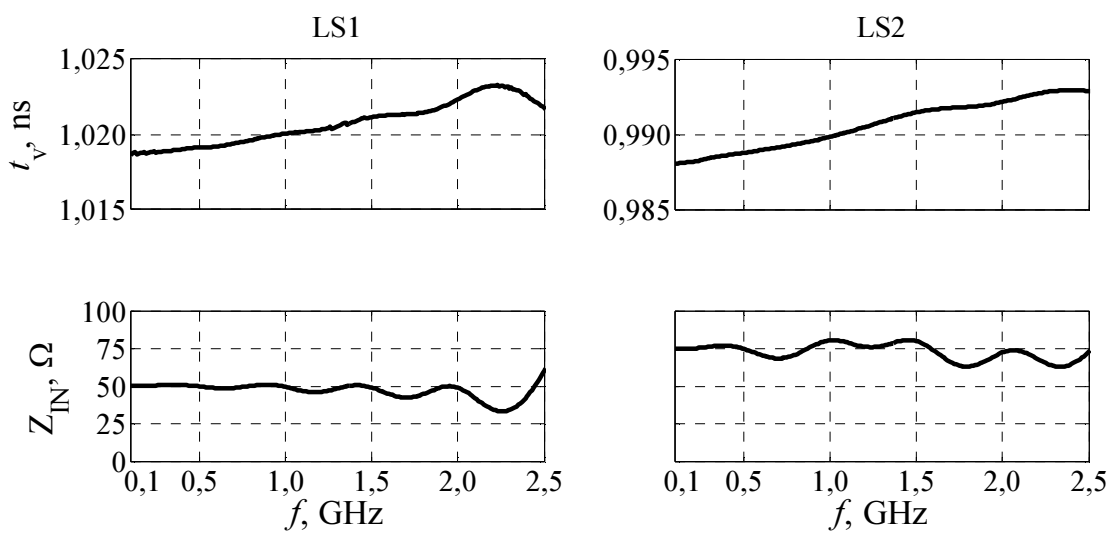

4.11 pav. Sintezuotų meandrinių lètinimo sistemų su papildomais ekranais įžemintais iš abiejų galų LS1 ir LS2 fazinès vèlinimo trukmès ir įèjimo varžos priklausomybès nuo dažnio

Fig. 4.11. Frequency response of phase delay time and input impedance of synthesized meander slow-wave system with additional shields grounded at both edges LS1 and LS2
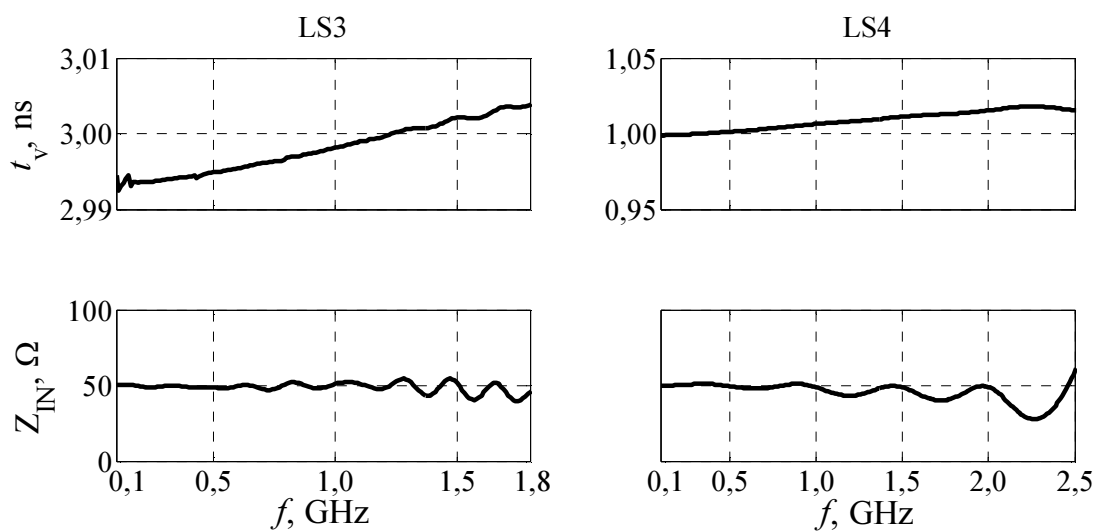

4.12 pav. Sintezuotų meandrinių lètinimo sistemų su papildomais ekranais įžemintais iš abiejų galų LS3 ir LS4 fazinès vẻlinimo trukmès ir įejjimo varžos priklausomybès nuo dažnio

Fig. 4.12. Frequency response of phase delay time and input impedance of synthesized meander slow-wave system with additional shields grounded at both edges LS3 and LS4

Trigubai didesnè vèlinimo trukmè, esant tokiai pačiai $50 \Omega$ iejjimo varžai, gaunama tris kartus padidinus laidininkų skaičių $N$, nežymiai padidinus meandro 
laidininko ilgị $2 A$ ir sumažinus papildomo ekrano plotị $w_{2}$ (LS1 ir LS3). Dėl šių pasikeitimų praleidžiamųjų dažnių juostos plotis $\Delta F$ sumažèja apie $33 \%$.

Pakeitus RO3006 ${ }^{\mathrm{TM}}$ dielektrinio pagrindo medžiagą i FR4, 1 nanosekundès vèlinimo trukmé ir $50 \Omega$ iejjimo varža gaunamos didinant meandro laidininko plotị $w_{1}$ ir ilgi $2 A$, taip pat didinant papildomo ekrano plotị $w_{2}$ bei mažinant tarpą tarp gretimų meandro juostelių $s$ (LS1 ir LS4). Praleidžiamųų dažnių juostos plotis šiuo atveju sumažeja apie $2 \%$.

4.2 lentelèje pateiktų sintezuotų lètinimo sistemų LS1-LS4 fazinès vèlinimo trukmès ir įejimo varžos dažninès priklausomybès pateiktos 4.11 ir 4.12 paveiksluose.

\subsection{Ketvirtojo skyriaus išvados}

Remiantis atliktais tyrimais ir jų rezultatų analize galima daryti šias išvadas:

1. Konstrukcinių parametru įtaka sistemos elektrinès charakteristikoms yra nevienoda. Todèl, sintezès procesui paspartinti būtina nustatyti meandrinių lètinimo sistemų su papildomais ekranais izžemintais iš abiejų galų konstrukcinių parametrų įtakos koeficientus įvertinančius sistemos fazinès vèlinimo trukmès, iejjimo varžos ir praleidžiamujjų dažnių juostos pločio jautrumą konstrukcinių parametrų keitimui.

2. Didžiausią įtaką meandrinès lètinimo sistemos su papildomais ekranais įžemintais iš abiejų galų fazinei vẻlinimo trukmei turi laidininko ilgio keitimas. Sumažinus laidininko ilgi vienu procentu, sistemos fazinès vèlinimo trukmès verte irgi sumažèja apie $1 \%$. Mažesnè itaka pastebima keičiant dielektrinio pagrindo parametrus: santykinę dielektrinę skvarbą ir storị . Keičiant kitus konstrukcinius parametrus - meandro laidininko ploti, papildomo ekrano ploti ir tarpo tarp gretimų meandro juostelių ploti, sistemos fazinè vèlinimo trukmè beveik nesikeičia.

3. Didžiausią įtaką meandrinès lètinimo sistemos su papildomais ekranais ižzemintais iš abiejų galų iejjimo varžai turi papildomo ekrano pločio $w_{2}$ keitimas. Sumažinus $w_{2}$ vienu procentu, sistemos iejejimo varža taip pat sumažèja apie $1 \%$. Mažesnè itaka pastebima keičiant tarpo tarp gretimų meandro juostelių plotị ir pagrindo santykinę dielektrinę skvarbą. Kitų konstrukcinių parametrų - dielektrinio pagrindo storio ir meandro laidininko pločio, itakos koeficientai yra dar mažesni ir siekia $0,2-0,3$. Tuo tarpu meandro laidininko ilgio keitimas sistemos įèjimo varžos žemuosiuose dažniuose nekeičia. 
4. Didžiausią įtaką sistemos praleidžiamụjų dažnių juostos pločiui turi meandro laidininko ilgio ir pagrindo santykinès dielektrinès skvarbos keitimas. Sumažinus šiuos didžius $1 \%$, praleidžiamujų dažnių juostos plotis padideja apie $1,36 \%$. Nemažą įtaką praleidžiamųjų dažnių juostos pločiui turi ir meandro laidininko pločio, tarpo tarp gretimų meandro laidininko pločio ir dielektrinio pagrindo storio pokyčiai. Sumažinus šiuos dydžius $1 \%$, praleidžiamujų dažnių juostos plotis padideja 0,68 \%. Papildomo ekrano pločio keitimas, itakos sistemos praleidžiamujų dažnių juostos pločiui neturi.

5. Konstrukcinių parametrų įtakos lètinimo sistemos elektrinèms charakteristikoms įvertinimas leido sudaryti meandrinių lètinimo sistemų su papildomais ekranais, ižemintais iš abieju galų parametrinès sintezès algoritmą, kurio tinkamumas patikrintas atliekant keturių lètinimo sistemų sintezę. 



\section{Bendrosios išvados}

1. Pasiūlyta metodika leidžia apskaičiuoti krūvio pasiskirstymą meandrinèse struktūrose trimateje erdveje. Krūvio pasiskirstymo tyrimas išryškino elektromagnetini ryši tarp gretimų meandro juostelių, kuris yra fazinès vèlinimo trukmès dispersijos priežastis. Todèl, siekiant pagerinti meandrinès letinimo sistemos dispersines savybes, sukurti ir ištirti keturi meandrinių lètinimo sistemų su papildomais ekranais kompiuteriniai modeliai, kurie skiriasi trumpiklių, jungiančių papildomą ir išorini ekranus, išdèstymo padètimi išilgai papildomo ekrano.

2. Kompiuteriniais eksperimentais parodyta, kad papildomų ekranų iterpimas didina sistemos vèlinimo trukmę žemuosiuose dažniuose ir tokiu būdu mažina jos dispersiją. Meandrinè lètinimo sistema su papildomais ekranais, įžemintais iš abiejų galų, pasižymi mažiausia vèlinimo trukmès dispersija. İterpus ì sistemą papildomus ekranus, ižemintus iš abiejų galų, lètinimo sistemos vèlinimo trukmès dispersija dažnių ruože iki $1,97 \mathrm{GHz}$ sumažèja apie 3,89 karto ir neviršija 0,035 ns.

3. Projektuojant meandrines lètinimo sistemas su papildomais ekranais tikslinga atsižvelgti ị kraštuose, kurių topologija gali turèti didelę itaką sistemos savybèms, vykstančius procesus. Šiuos procesus galima 
įvertinti tiriant modelius, atspindinčius pokyčius meandrinès lètinimo sistemos su papildomais ekranais gretimu juostelių sujungimo vietoje ir tarpuose ties meandro kilpomis ir atviraja jo dalimi.

4. Meandrinių lètinimo sistemų su papildomais ekranais ir modifikuotomis kraštų topologijomis tyrimas parodè, kad laidininko, jungiančio gretimas meandro juosteles, pločio keitimas didina sistemos vèlinimo trukmę. Tai paaiškinama talpinių netolygumų sudarymu meandriniame laidininke. Be to, sumažinti bendrą sistemos plotą nekeičiant jos dispersinių savybių galima didinant tarpą kraštuose ties meandro kilpomis. Esant meandrinio laidininko ilgiui $19 \mathrm{~mm}$, tarpo pločiui $0,5 \mathrm{~mm}$ ir tarpo ilgiui $0,6 \mathrm{~mm}$, sistemos plotas sumažèja apie $3 \%$.

5. Pasiūlyta meandrinès lètinimo sistemos su papildomais ekranais įèjimo varžos nustatymo metodika leido kompiuteriniais tyrimais įrodyti, kad iejjimo varža kraštuose yra pastovi dažnių ruože iki $1,5 \mathrm{GHz}$, sistemos viduryje - iki $2 \mathrm{GHz}$, o jos verte žemuosiuose dažniuose yra tokia pati kaip ir sistemos kraštuose.

6. Meandrinių lètinimo sistemų su papildomais ekranais, įžemintais iš abiejų galų konstrukcinių parametrų įtakos koeficientų nustatymas ir sistemos fazinès vélinimo trukmès, iejjimo varžos ir praleidžiamuju dažnių juostos pločio jautrumo konstrukcinių parametrų keitimui ivertinimas leido sudaryti meandrinių lètinimo sistemu su papildomais ekranais, įžemintais iš abiejų galų, parametrinès sintezès algoritmą, kuris patikrintas atliekant keturių lètinimo sistemų sintezę. 


\section{Literatūra ir šaltiniai}

Abbosh, A. M. 2009. Analytical Closed-Form Solutions for Different Configurations of Parallel-Coupled Microstrip Lines, IET Microwaves, Antennas \& Propagation 3(1): 137-147.

Abdulhadi, E. A; Abhari, R. 2012. Design and Experimental Evaluation of Miniaturized Monopole UHF RFID Tag Antennas, IEEE Antennas and Wireless Propagation Letters 11: $248-251$.

Amini, M. H.; Hassani, H. R. 2013. Compact Polarisation Reconfigurable Printed Monopole Antenna at $2.4 \mathrm{GHz}$, Electronics Letters 49(17): 1049-1050.

Bai, N; Gu, L; Shen, C; Feng, J; Liao, F; Sun, X. 2013. S-Shaped Microstrip MeanderLine Slow-Wave Structure for W-Band Travelling-Wave Tube, in IEEE Fourteenth International Vacuum Electronics Conference (IVEC), Paris, France, 1-2.

Ban, Y. L.; Liu, C. L.; Li, J. L. W.; Guo, J.; Kang, Y. 2013. Small-Size Coupled-Fed Antenna With Two Printed Distributed Inductors for Seven-Band WWAN/LTE Mobile Handset, IEEE Transactions on Antennas and Propagation 61(11): 5780-5784.

Bhattacharjee, P. S.; Das, S.; Chowdhury, S. K. 1995. Characteristic Impedance of Coupled Microstrip Lines, in IEEE International Symposium on Electromagnetic Compatibility, Atlanta, USA, 137-138.

Bondeson, A.; Rylander, T.; Ingelström, P. 2005. Computational Electromagnetics. New York: Springer. $244 \mathrm{p}$. 
Bulja, S.; Mirshekar-Syahkal, D.; Yazdanpanahi, M; James, R; Day, S. E.; Fernandez, F. A. 2010. Liquid Crystal Based Phase Shifters in $60 \mathrm{GHz}$ Band, in Proceedings of the Third European Wireless Technology Conference, Paris, France, 37-40.

Burklund, C. 1961. A Broadband Megawatt Traveling Wave Tube Utilizing a RingLoaded Meander Line Interaction Circuit, in International Electron Devices Meeting, Washington, USA, p. 8.

Cantaragiu, S. 1999. Analysis of Shielded Microstrip Lines by Finite-Difference Method, in IEEE Sixth International Conference on Electronics, Circuits and Systems, Pafos, Cyprus, 565-567.

Cerjanic, A.; Sheikman, B.; Chatterjee, I. 2012. Method of Moments Modeling of Microstrip Patch Antennas with Automatic GPU Acceleration, in IEEE MTT-S International Microwave Symposium Digest (MTT), Montreal, Canada, 1-3.

Chen, Z.; Aditya, S.; Chua, C. 2013. Analysis of Coupled Planar Helices with StraightEdge Connections for Application in Millimeter-Wave TWTs, IEEE Transactions on Electron Devices 60(3): 1244-1250.

Chiu, H. C.; Lai, C. H.; Ma, T. G. 2012. Miniaturized Rat-Race Coupler with Out-ofBand Suppression Using Double-Layer Synthesized Coplanar Waveguides, in IEEE MTT-S International Microwave Symposium Digest (MTT), Montreal, Canada, 1-3.

Chua, C.; Aditya, S.; Tsai, J.; Shen, Z. 2012. PIC Simulation for W-Band Planar Helix with Straight-Edge Connections, in IEEE Thirteenth International Vacuum Electronics Conference (IVEC), Monterey, USA, 459-460.

Chua, C.; Aditya, S. 2013. A 3-D U-Shaped Meander-Line Slow-Wave Structure for Traveling-Wave-Tube Applications, IEEE Transactions on Electron Devices 60(3): 1251-1256.

Chua, C.; Tsai, M. J.; Aditya, S.; Tang, M.; Wee Ho, S.; Shen, Z.; Wang, L. 2011. Microfabrication and Characterization of W-Band Planar Helix Slow-wave Structure With Straight-Edge Connections, IEEE Transactions on Electron Devices 58(11): 4098-4105.

Cusick, M.; Begum, R.; Gajaria, D.; Grant, T.; Kolda, P.; Legarra, J.; Meyer, C.; Ramirez-Aldana, J. L.; San Pedro, D.; Stockwell, B.; Yamane, G. 2012. 700 W Ka-Band Coupled-Cavity Traveling Wave Tubes (CCTWT) for Communication, in IEEE Thirteenth International Vacuum Electronics Conference (IVEC), Monterey, USA, 227-228.

Das, A.; Dhar, S.; Gupta, B. 2011. Lumped Circuit Model Analysis of Meander Line Antennas, in $11^{\text {th }}$ Mediterranean Microwave Symposium (MMS), Hammamet, Tunisia, 21-24.

Deo, P.; Mirshekar-Syahkal, D.; Seddon, L.; Day, S. E.; Anibal Fernandez, F. 2013. Liquid Crystal Based Patch Antenna Array for $60 \mathrm{GHz}$ Applications, in IEEE Radio and Wireless Symposium, Austin, USA, 127-129.

Faudzi, N. M.; Ali, M. T.; Ismail, I.; Ya’acob, N.; Jumaat, H.; Sukaimi, N. H. M. 2013. UHF-RFID Tag Antenna with Miniaturization Techniques, in $10^{\text {th }}$ International Conference on Electrical Engineering/Electronics, Computer, Telecommunications and Information Technology (ECTI-CON), Krabi, Thailand, 1-5. 
Fei, S.; Yan-Yu, W.; Xiong, X.; Hai-Rong, Y.; Yu-Bin, G.; Wen-Xiang, W. 2012. Study on a W-Band Modified V-Shaped Microstrip Meander-Line Traveling-Wave Tube, China Physics B 21(6): 064210

Fooks, E. H.; Zakarevicius, R. A. 1990. Microwave Engineering Using Microstrip Circuits. Australia: Prentice Hall. 333 p.

Ge, L.; Wang, J. P.; Guo, Y. X. 2010. Compact Microstrip Lowpass filter with UltraWide Stopband, in Electronics Letters 46(10): 689-691.

Gorur, A.; Karpuz, C. 2007. Miniature Dual-Mode Microstrip Filters, in IEEE Microwave and Wireless Components Letters 17(1): 37-39.

Guney, K.; Erler, M.; Sagiroglu, S. 1999. Artificial Neural Networks for the Characteristic Impedance Calculation of Conductor-Backed Coplanar Waveguides, in International Conference on Electrical and Electronics Engineering (ELECO), Bursa, Turkey, 224228.

Gurskas, A.; Urbanavicius, V.; Martavicius, R. 2010. Evaluation of the Microstrip Lines Connectors in the Meander Delay Line Model, Electronics and Electrical Engineering 99(3): 39-42.

Hansuek, L.; Tong, C.; Jiang, L.; Vahala, K. 2012. Ultra-Low-Loss Delay Lines and Resonators on a Silicon Chip, in IEEE Photonics Conference (IPC), Burlingame, USA, $518-519$.

Harrington, R. F. 1967. Matrix Methods for Field Problems, in Proceedings of the IEEE 55(2): 136-149.

Harrington, R. F. 1968. Field Computation by Moment Methods. New York: Macmillan. 229 p.

He, Z.; Zhan, G.; Li, Z. 2012. Research on Passive Meander-Lined Radio Frequence Identification Tag Antenna on Ultrahigh Frequency, in Fifth International Conference on Biomedical Engineering and Informatics, Chongqing, China, 1507-1510.

Yang, J. G.; Yongsik, J.; Sunkyu, C.; Kyounghoon, Y. 2006. A New Compact 3-D Hybrid Coupler Using Multi-Layer Microstrip Lines at $15 \mathrm{GHz}$, in Proceedings of the 36th European Microwave Conference, Manchester, UK, 25-28.

Jinglin, S.; Yong-Zhong, X.; Sanming, H.; Lei, W.; Bo, Z. 2010. Controllable SlowWave Delay Line, in IEEE Electrical Design of Advanced Packaging \& Systems Symposium (EDAPS), Singapore, Singapore, 1-4.

Kallmann, H. E. 1946. Equalized Delay Lines, in Proceedings of the IRE 34(9): 646657.

Katkevičius, A. 2013. Spiralinių ir meandrinių lètinimo sistemų dažninių savybių tyrimas, daktaro disertacija. VGTU, Vilnius: Technika. 119 p.

Katkevičius, A. 2010. Linijų su periodiniais netolygumais savybių tyrimas, Mokslas Lietuvos ateitis 2(1): 108-111.

Khajooeizadeh, A.; Abhari, R. 2008. Compact Metal Insulator Semiconductor Delay Lines, Journal of Applied Physics 103(4): 044909. 
Khajooeizadeh, A.; Abhari, R. 2006. Design of Compact Meander Delay Lines on Si Substrate, in IEEE Electrical Performance of Electronic Packaging, Scottsdale, USA, 141-144.

Kim, G.; Lu, A. C.; Wei, F.; Wai, L. L.; Kim, J. 2008. 3D Strip Meander Delay Line Structure for Multilayer LTCC-Based SiP Applications, in Electronic Components and Technology Conference, Lake Buena Vista, USA, 2081-2085.

Kleiza, A.; Štaras, S. 1998. Meandrinių laidininkų išilginių atkarpu įtaka, iš Elektronika'98: Tarptautinès konferencijos medžiaga, Kaunas, 79-81.

Kowalski, G. 1974. Coplanar Printed Meader Lines, Arch. Elektron. Ubertragungstech. 28(6): 257-262.

Krukonis, A. 2013. Mikrojuostelinių lètinimo sistemu tyrimas dažniniais ir laiko metodais, daktaro disertacija, VGTU, Vilnius: Technika. 129 p.

Krukonis, A.; Mikucionis, S.; Urbanavicius, V. 2013. The Influence of Non-Uniformity of the Multi-Conductor Line Parameters on Frequency Responses of the Meander Delay Line, Electronics and Electrical Engineering 19(6): 81-86.

Krukonis, A.; Urbanavicius, V. 2011. Investigation of Microstrip Lines Dispersion by the FDTD Method, Electronics and Electrical Engineering 115(9): 51-54.

Kui-Song, Z.; Gao, W.; Jia-Dong, X.; Jian-Ying. L. 2011. Simulation and Measurement of an Planar Two-Element Antenna Array with Metamaterials, in Cross Strait QuadRegional Radio Science and Wireless Technology Conference, Harbin, China, 13-16.

Lin, S.; Cui, H.; Wu, L.; Wang, W.; Sun, X. 2012. Design of Broadside-Coupled Parallel Line Millimetre-Wave Filters by Standard 0.18- $\mu \mathrm{m}$ Complimentary Metal Oxide Semiconductor Technology, IET Microwaves, Antennas \& Propagation 6(1): 72-78.

Lin, S.; Sun, X.; Li, L.; Wang, W.; Yang, L. 2009. Equivalent Circuit Design of Compacted K-Band Bandpass Filters by Standard 0.18- $\mu \mathrm{m}$ CMOS Technology, in Proceedings of the $4^{\text {th }}$ European Microwave Integrated Circuits Conference, Rome, Italy, 290293.

Ling-jiang, Z.; Bo, Z.; Zheng-hui, X.; Wei-ming, L.; Wu, R. 2012. Analysing Periodic Structures using FDTD Algorithm, in International Conference on Microwave and Millimeter Wave Technology (ICMMT), Shenzhen, China, 1-4.

Liu, L.; Wei, Y.; Xu, J.; Lu, Z.; Yin, H.; Yue, L.; Gong, H.; Zhao, G.; Duan, Z.; Wang, W.; Gong, Y. 2013. A Novel Slotted Helix Slow-Wave Structure for Millimeter-Wave Traveling-Wave Tube, Progress in Electromagnetics Research 135: 347-362.

Liu, L.; Wei, Y.; Xu, X.; Shen, F.; Zhao, G.; Huang, M.; Tang, T.; Wang, W. X.; Gong, Y. 2012. A Novel Helical Slow-Wave Structure for Millimeter-Wave Traveling-Wave Tube, in $5^{\text {th }}$ Global Symposium on Millimeter Waves (GSMM), Harbin, China, 312-315.

Лошаков, Л. Н.; Ольдерогге, Е. Б. 1948. К теории коаксиальной спиральной линии, Радиотехника 3(2): 11-20.

Лошаков, Л. Н.; Шумская Л. Н.; Иванова, Н. Е. 1980. К расчету медленной волны в спиральной линии с эллиптическим поперечным сечением, Радиотехника и электроника 25(11): 2286-2291. 
Ma, Z. L.; Jiang, L. J.; Xi, J.; Ye, T. T. 2012. A Single-Layer Compact HF-UHF DualBand RFID Tag Antenna, IEEE Antennas and Wireless Propagation Letters 11: 12571260.

Martavičius, R. 1996. Elektrodinaminès planarinès lètinimo sistemos plačiajuosčiams elektroniniams prietaisams. Vilnius: Technika. 264 p.

Martavičius, R.; Jurjevas, A. 1999. Meandrinių lètinimo sistemų su šukų pavidalo papildomais ekranais modelis, Elektronika ir Elektrotechnika 21(3): 53-57.

Martavičius, R.; Jurjevas, A. 2000. Plačiajuosčių mikrojuostelinių meandrinių lètinimo sistemų savybės, Elektronika ir Elektrotechnika 28(5): 43-48.

Martavičius, R.; Jurjevas, A. 2001. Patikslinti plačiajuosčių meandrinių lètinimo sistemų modeliai, Elektronika ir Elektrotechnika 34(5): 38-43.

Martavičius, R.; Urbanavičius, V. 1996. Netolygaus žingsnio daugialaidès linijos, Elektronika ir elektrotechnika 8(4): 24-30.

Martavičius, R.; Urbanavičius, V. 1997. Meandrinių lètinimo sistemų banginè ir iejjimo varža, Elektronika ir elektrotechnika 10(1): 14-17.

Martavičius, R.; Urbanavičius, V. 1998. Ekranų įtaka mikrojuostelinių meandrinių vèlinimo linijų savybėms, Elektronika ir elektrotechnika 16(3): 42-46.

Martavičius, R.; Urbanavičius, V. 1999. Žingsnio netolygumo ịtaka meandrinių lètinimo sistemų savybėms, Elektronika ir elektrotechnika 21(3): 65-68.

Mittal, S.; Kaushik, B. K.; Yadav, K. L.; Sharma, D. K.; Majumder, M. K. 2012. Crosstalk Effect in Coupled Interconnect Lines Using FDTD Method, in International Conference on Communications, Devices and Intelligent Systems (CODIS), Kolkata, India, 365-368.

Nara, S.; Koshiji, K. 2006. Study on Delay Time Characteristics of Shielded Meander Lines, in $17^{\text {th }}$ International Zurich Symposium on Electromagnetic Compatibility, Singapore, 324-327.

Nara, S.; Koshiji, K. 2007. Characteristics of Phase-Delay Time on Meander Differential Signal Lines and a Shielded Meander Differential Signal Line, in $18^{\text {th }}$ International Zurich Symposium on Electromagnetic Compatibility, Munich, Germany, 217-220.

Navickas, R. 2013. Self-Formation Processes in High-Speed Integrated Circuits, in $31^{s t}$ Norchip Conference, Vilnius, Lithuania, 1-8.

Nguyen, L. B.; Antonsen, T. M. Jr., Nusinovich, G. S. 2013. Open Planar Sheath Slowwave System, in IEEE International Conference on Plasma Science (ICOPS), San Francisco, USA, 1-2.

Niklas, W. F.; Wimpffen, J. 1958. Oscilloscope Tube with Traveling Wave Deflection System and Large Field of View, Journal of the British Institution of Radio Engineers 18(11): 653-660.

Olaode, O. O.; Devereux Palmer, W.; Joines, W. T. 2012. Characterization of Meander Dipole Antennas with a Geomerty-Based, Frequency-Independent Lumped Element Model, IEEE Antennas and Wireless Propagation Letters 11: 346-349. 
Piekarz, I.; Sorocki, J.; Wincza, K.; Gruszczynski, S.; Muller, J.; Welker, T. 2012. Meandered Coupled-Line Single-Section Directional Coupler Designed in Multilayer LTCC Technology, in $20^{\text {th }}$ Telecommunications Forum (TELFOR), Belgrade, Serbia, 983-986.

Pomarnacki, R. 2011. Elektrodinaminių lètinimo įtaisų tyrimas taikant lygiagrečiąsias kompiuterines sistemas, daktaro disertacija, VGTU, Vilnius: Technika. 123 p.

Pomarnacki, R.; Krukonis, A.; Urbanavičius, V. 2010. Parallel Algorithm for the QuasiTEM Analysis of Microstrip Multiconductor Line, Electronics and Electrical Engineering 101(5): 83-86.

Prodromakis, T.; Papavassiliou, C.; Konstantinidis, G. 2007. A Miniaturized Delay Line Based on Slow-Wave Substrates, in IEEE International Symposium on Circuits and Systems, New Orleans, USA, 369-372.

Radhakrishnan, K.; Chew, W. C. 2000. Efficient Analysis of Microstrip Structures with Multiple Discontinuities, in IEEE Antennas and Propagation Society International Symposium 1: 124-127.

Rashed-Mohassel, J. 1991. The Radiation Characteristics of a Resonant Meander Line Section as a Monopole, Microwave and Optical Technology Letters 4(12): 537-540.

Rautio, J. C.; Harrington, R. F. 1987. An Electromagnetic Time-Harmonic Analysis of Shielded Microstrip Circuits, IEEE Transactions on Microwave Theory and Techniques 35(8): 726-730.

Rosales, O. S.; Suster, D. 1995. Finite-Difference Computation of the Characteristic Impedance of Unbounded Striplines and Microstrip Line, in Proceedings of the First IEEE International Caracas Conference on Devices, Circuits and Systems, Caracas, Venezuela, 323-327.

Sadiku, M. N. O. 2001. Numerical techniques in electromagnetics. New York: CRC Press. 760 p.

Sadiku, M. N. O.; Musa, S. M.; Nelatury, S. R. 2007. Comparison of Approximate Formulas for the Capacitance of Microstrip Line, in Proceedings of IEEE SoutheastCon, Richmond, USA, 427-432.

Sato, R. 1971. A Design Method for Meander-Line Networks Using Equivalent Circuit Transformations, IEEE Transactions on Microwave Theory and Techniques 19(5): 431442.

Sato, Y.; Campelo, F.; Igarashi, H. 2013. Meander Line Antenna Design Using an Adaptive Genetic Algorithm, IEEE Transactions on Magnetics 49(5): 1889-1892.

Sengele, S.; Jiang, H.; Booske, J. H.; Kory, C. L.; van der Weide, D. W.; Lawrence Ives, R. 2009. Microfabrication and Characterization of a Selectively Metallized W-Band Meander-Line TWT Circuit, IEEE Transactions on Electron Devices 56(5): 730-737.

Sheng, X.-Q.; Song, W. 2012. Essentials of Computational Electromagnetics. Singapore: John Wiley \& Sons. 352 p.

Shu-Yin, H.; Wen-Jiao, L. 2012. A Delay Line Based on Synthesized Coplanar Waveguide, in International Conference on Microwave and Millimeter Wave Technology (ICMMT), Shenzhen, China, 1-4. 
Skudutis, J.; Daškevičius, V.; Garšva, E. 2004. Microwave Office programų paketo taikymo lètinimo sistemoms tirti patirtis, Elektronika ir elektrotechnika 52(3): 68-74.

Skudutis, J.; Daškevičius, V. 2001. Bendraašių spiralių lètinimo sistemos savybių tyrimas, Elektronika ir elektrotechnika 34(5): 32-37.

Skudutis, J.; Daškevičius, V. 2002. Lètinimo ir kreipimo sistemos įèjimo varžos tyrimas, Elektronika ir elektrotechnika 42(7): 13-17.

Skudutis, J.; Daškevičius, V. 2006. Spiralinès lètinimo sistemos savybių tyrimas programų paketu MicroWave Studio, Elektronika ir elektrotechnika 65(1): 38-42.

Soliman, E. A.; Sallam, O.; De Raedt, W.; Vandenbosch, G. A. E. 2012. Miniaturized RFID Tag Antenna Operating at $915 \mathrm{MHz}$, IEEE Antennas and Wireless Propagation Letters 11: 1068-1071.

Sultan, K. S.; Abdullah, H. H.; Abdullah, E. A.; Hashish, E. A. 2012. Low SAR, Compact and Multiband Antenna for Mobile and Wireless Communication, in Middle East Conference on Antennas and Propagation (MECAP), Cairo, Egypt, 1-5.

Sumathy, M.; Datta, S. K.; Kumar, L. 2013. Folded Meander-Line Slow-Wave Structure for Millimeter-Wave TWTs, in IEEE $14^{\text {th }}$ International Vacuum Electronics Conference, Paris, France, 1-2.

Ширман, Я. Д.; Вайнорис, З. А. 1959. Основы теории спиральной линии задержки, Радиотехника и электроника 4(9): 1486-1492.

Štaras, S.; Skudutis, J. 1996. The Influence of Dielectric Holders on Characteristics of Meander Slow-Wave Structure, Baltic Electronics 2(1): 37-38.

Štaras, S. 2008. Ivadas $i$ skaitmeninius elektrodinamikos metodus ir ju taikymą. Vilnius: Technika. $186 \mathrm{p}$.

Štaras, S. Martavičius, R.; Skudutis, J.; Urbanavičius, V.; Daškevičius, V. 2010. Plačiajuosčių lètinimo ịtaisų modeliavimas ir taikymas: monografija. Vilnius: Technika. 442 p.

Štaras, S.; Martavičius, R.; Skudutis, J.; Urbanavičius, V.; Daškevičius, V. 2012. Wideband slow-wave systems: simulation and application. New York: Taylor \& Francis Group. 460 p.

Štaras, S.; Burokas, T. 2003. Nevienalyčių spiralinių sistemų savybės, Elektronikas ir Elektrotechnika 43(1): 17-20.

Štaras, S.; Burokas, T. 2004. Lètinimo-kreipimo sistemų ir jų jungių modeliavimas ir tobulinimas, Elektronikas ir Elektrotechnika 50(1): 9-15.

Štaras, S.; Burokas, T. 2006. Kvazisimetrinès spiralinès kreipimo sistemos modelis ir savybès, Elektronikas ir Elektrotechnika 66(2): 63-68.

Tanaka, H.; Banba, N.; Arai, S.; Nishikawa, T. 1994. 2 GHz One Octave-Band 90 Degree Hybrid Coupler Using Coupled Meander Line Optimized by 3-D FEM, in IEEE MTT-S International Microwave Symposium Digest, San Diego, USA, 903-906.

Tascone, R.; Savi, P.; Trinchero, D.; Orta, D. 2000. Scattering Matrix Approach for the Design of Microwave Filters, IEEE Transaction on Microwave Theory and Techniques 48(12): 423-430. 
Thom, A.; Apelt, C. J. 1961. Field Computations in Engineering and Physics. London: D. Van Nostrand. 165 p.

Trani, P.; Antoine, P. 2012. MPM for ECM systems, in IEEE Thirteenth International Vacuum Electronics Conference (IVEC), Monterey, USA, 149-150.

Umayahara, Y.; Nishikawa, Y. 2003. Glass Ceramics dielectric material and sintered glass ceramics. USA Patent No. 6649550

Urbanavičius, V.; Martavičius, R. 2006. Model of the Microstrip Line with a NonUniform Dielectric, Electronics and Electrical Engineering 67(3): 55-60.

Ureel, J.; De Zutter, D. 1996. Shape Sensitivities of Capacitances of Planar Conducting Surfaces Using the Method of Moments, IEEE Transactions on Microwave Theory and Techniques 44(2): 198-207.

Vainoris, Z. 2004. Bangu elektronikos pagrindai. 1-oji laida. Vilnius: Technika. 513 p.

Вайнорис, 3.; Кирвайтис, Р.; Штарас, С. 1986. Электродинамические задерживающие и отклоняющие системы. Вильнюс: Мокслас. 266 с.

Wang, J.; Xu, L. J.; Zhao, S.; Guo, Y. X.; Wu, W. 2010. Compact Quasi-Elliptic Microstrip Lowpass Filter with Wide Stopband, Electronics Letters 46(20): 1384-1385.

Wang, S.; Gong, Y.; Hou, Y.; Wang, Z.; Wei, Y.; Duan, Z.; Cai, J. 2013. Study of a Log-Periodic Slow Wave Structure for Ka-Band Radial Sheet Beam Traveling Wave Tube, IEEE Transactions on Plasma Science 41(8): 2277-2282.

Wang, J.; Wei, B.; Cao, B.; Zhang, X.; Guo, X.; Song, X. 2013. A UHF-Band NarrowBand HTS Bandpass Filter With Wide Stopband Using Interdigital Structure, IEEE Transactions on Applied Superconductivity 23(6): 1502108.

Watanabe, Y.; Watanabe, K.; Igarashi, H. 2011. Optimization of Meander Line Antenna Considering Coupling Between Nonlinear Circuit and Electromagnetic Waves for UHFBand RFID, IEEE Transactions on Magnetics 47(5): 1506-1509.

Wei-Shan, S.; Kye-Kas, S.; Chang, R. W.-Y.; Oswal, M.; Ling-Biao, W. 2009. Comprehensive Analysis of Serpentine Line Design, IEEE Asia Pacific Microwave Conference APMC2009, Singapore, 1285-1288.

Wheeler, H. A. 1964. Transmission-line properties of parallel wide strips by a conformal-mapping approximation, IEEE Microwave theory and techniques 12(3): 280-289.

Wu, J.; Lou, J.; Li, M.; Yang, G.; Yang, X.; Adams, J.; Sun, N. X. 2012. Compact, LowLoss, Wideband, and High-Power Handling Phase Shifters with Piezoelectric Transducer-Controlled Metallic Pertruber, IEEE Transactions on Microwave Theory and Techniques 60(6): 1587-1594.

Xu, L.; Yang, Z. H.; Li, J. Q.; Li, B. 2012. Accurate and Fast Finite-Element Modeling of Attenuation in Slow-Wave Structures for Traveling-Wave Tubes, IEEE Transactions on Electron Devices 59(5): 1534-1541.

Zhewang, M.; Miyata, A.; Yamashita, E. 1996. Analysis of Compensated Structures in Planar Transmission Lines Using the FDTD Method Incorporating Triangular Subcells, in IEEE MTT-S International Microwave Symposium Digest, San Francisco, USA, 1015-1018. 


\section{Autoriaus mokslinių publikaciju disertacijos tema sąrašas}

\section{Straipsniai recenzuojamuose mokslo žurnaluose}

Metlevskis, E.; Urbanavičius, V. 2011. Analysis of Charge Distribution on Rectangular Microstrip Structures, Acta Physica Polonica A. 119(4): 503-508. ISSN 05874246. (Thomson Reuters Web of Knowledge)

Metlevskis, E. 2012. Planariujų plačiajuosčių lètinimo sistemų taikymo sritys, Mokslas Lietuvos ateitis 4(1): 85-88. ISSN 2029-2341. (ICONDA, Gale®, ProQuest, EBSCOhost, IndexCopernicus)

Metlevskis, E.; Martavičius, R. 2012. Computer Models of Meander slow-wave system with additional shields, Electronics and electrical engineering. 119(3): 61-64. ISSN 1392-1215 ( Thomson Reuters Web of Knowledge).

Metlevskis, E.; Martavičius, R. 2014. Frequency Characteristics of the Input Impedance of Meander Slow-wave System with Additional Shields, Electronics and electrical engineering. 20(4): 59-62. ISSN 1392-1215 (Thomson Reuters Web of Knowledge).

\section{Straipsniai kituose leidiniuose}

Metlevskis, E.; Martavičius, R. 2012. Calaculation of Characteristics of Meander Slowwave System with Additional Shields, in EMD'2012 proceedings of the XXII interna- 
tional conference on electromagnetic disturbances: 87-90. ISSN 1822-3249. ISBN 9786094572609. 


\section{Summary in English}

\section{Introduction}

\section{The investigated problem}

In a common meander slow-wave system phase delay time is highly dependent on the frequency of propagated signal - the higher the frequency the higher the phase delay time. The reason for that is the frequency dependent electromagnetic interaction between adjacent meander strips. In order to reduce the electromagnetic interaction, additional shields are inserted between adjacent meander conductors and connected to an external shield by vias.

Analytical analysis methods are often chosen for an analysis of meander slow-wave systems. Such methods don't take into account the ongoing processes on the edges and ends of meander conductor. Processes can be taken into account by analyzing models of meander slow-wave systems that are based on numerical methods.

Evaluation of influence of additional shields on frequency properties of meander slow-wave systems is discussed in dissertation.

\section{Importance of the thesis}

Meander slow-wave systems are widely used in antennas, monolithic microwave integrated circuits and high speed digital devices. Filters, couplers and phase shifters can be made using meander slow-wave systems, whose fabrication process is simpler and cheaper, compared to common waveguide structures. 
First meander slow-wave system was designed in 1960's. Their models were based on analytical methods. For example models based on equivalent circuit method were made solving electromagnetic problem with various assumptions. However this method doesn't allow to estimate the structure of electric field in the slow-wave system, moreover it can only be used in limited frequency range. Later models of different complexity were based on multiconductor line method. Using this method a system of infinite length is often modeled, which doesn't take into the account the effects on the ends of the system. At the end of XX century with the improvement of computers, first commercial electromagnetic field solvers based on numerical methods were created. Such software can be applied for design of slow-wave systems and allows creating precise models of complex slow-wave systems.

In a common meander slow-wave system phase the frequency dependent electromagnetic interaction between adjacent meander strips has an influence on phase delay time. In order to reduce the electromagnetic interaction, additional shields are inserted between adjacent meander conductors and connected to an external shield by vias. Structure of such meander slow-wave system is complex, therefore it is purposeful to design them using models based on numerical methods.

Propagation processes of electromagnetic waves on the edges and ends of slowwave system with additional shields have influence on its dispersive properties. Moreover in literature there are no data about frequency response of input impedance and Sparameters of such systems. Therefore it is relevant to create new models of meander slow-wave systems with additional shields which allow extending the limits of their operating frequency, reducing the dispersion of phase delay time and evaluating the compatibility of a system with a signal tract.

\section{The object of research}

Object of research - planar meander slow-wave system with additional shields, their models and methods of analysis and synthesis.

\section{Goal of the thesis}

Goal of the thesis is to investigate the planar meander slow-wave systems with additional shields, to create new models and their investigation techniques which allow evaluating the processes on the edges and ends of slow-wave system, creating technique for parametric synthesis of such systems.

\section{Tasks of the thesis}

To achieve the goal of the thesis, following tasks have to be solved:

1. Create a technique for modeling of 3D distribution of electric field in meander slow-wave system using method of moments and investigate the structure of electric field in planar meander slow-wave systems.

2. Create models of planar meander slow-wave systems with additional shields using dedicated software. 
3. Investigate the ongoing effects on the edges and ends of planar meander slowwave systems with additional shields and their influence on system's dispersive properties and frequency response of input impedance.

4. Create a technique for parametric synthesis of planar meander slow-wave systems with additional shields.

\section{Research methodology}

Throughout this work method of moments is used for solution of electrodynamical tasks. Models of meander slow-wave systems with additional shields are implemented and analyzed using moment method based Sonnet ${ }^{\circledR}$ software, Matlab ${ }^{\circledR}$ is used for data processing.

\section{Importance of scientific novelty}

Dissertation provides following novelty in the field of electrical and electronics engineering:

1. A technique based on moment method for modeling of 3D distribution of electrical field in planar meander slow-wave systems is created and investigation results are obtained.

2. Models of planar meander slow-wave systems with additional shields are created and implemented using moment method based software and influence of ongoing effects on the edges and ends of such systems on their dispersion of phase delay time is investigated.

3. A technique for determination of input impedance of meander slowwave system with additional shields using moment method based software Sonnet ${ }^{\circledR}$ is created and frequency properties of input impedance are investigated.

4. Analysis of sensitivity of electrical properties to the changes of constructive parameters of meander slow-wave system with additional shields grounded at both edges is performed, influence coefficients are obtained and technique for parametric synthesis is created.

\section{Practical significance of achieved results}

A technique for modeling of 3D distribution of electric field in meander slow-wave system using method of moments and investigate the structure of electric field in planar meander slow-wave systems is created. Models of planar meander slow-wave systems with additional shields which allow taking into account the processes of propagation of electromagnetic waves on their edges and ends are created. Technique for determination of frequency response of input impedance of meander slow-wave system with additional shields which is needed for compatibility of a system with a signal tract is created. Technique of parametric synthesis which allow to synthesize the constructive parameters of meander slow-wave system with additional shields grounded at both edged in accordance with systems electrical parameters. 


\section{The Defended statements}

1. When additional shields are inserted in the meander slow-wave system and are grounded at both edges, dispersion of phase delay time of a system is reduced and in the frequency range up to $1.97 \mathrm{GHz}$ is less than $0.035 \mathrm{~ns}$.

2. Increase of a gap in the area where meander conductors forms a loop increases a phase delay time, which in the lower frequencies can be equalized by reducing a meander conductor length $2 A$. Thus, total area of a system is reduced, while its dispersive properties are unchanged. For given length of a meander conductor $19 \mathrm{~mm}$, gap width of $0.5 \mathrm{~mm}$ and gap length of $0.6 \mathrm{~mm}$, systems area is reduced about $3 \%$.

3. Proposed technique is applicable for determination of input impedance at the edges and in the center of planar meander slow-wave system with additional shields. Input impedance at the edges of a system is permanent in the frequency range up to $1.5 \mathrm{GHz}$. In the center input impedance is permanent in the frequency range up to $2 \mathrm{GHz}$ and its value in lower frequencies is the same as at the edges of a system.

4. A synthesis technique based on influence coefficients of constructive parameters of meander slow-wave system with additional shield grounded at both edges allows an automatic design of such systems.

\section{Approval of the results}

Five articles are published on the subject of dissertation - three in scientific journals included in Thomson Reuters Web of Knowledge list (Metlevskis, Urbanavičius 2011; Metlevskis, Martavičius 2011; Metlevskis Martavičius 2014); one in scientific journal listed in other international databases (Metlevskis 2012); one paper in reviewed international conference proceedings (Metlevskis, Martavičius 2012).

Dissertation research results have been announced in eight scientific conferences in Lithuania and abroad.

\section{The structure of dissertation}

Dissertation consists of introduction, four chapters, general conclusions, lists of references and author's publications on the subject of dissertation and summary in English. The total scope of dissertation - 116 pages, 38 indexed equations, 50 pictures, 7 tables, 115 references have been used.

\section{Review of broadband planar slow-wave systems and their methods of analysis}

In microwave devices, interaction of electromagnetic field and electrons is used. In traveling wave tubes velocities of electromagnetic wave and electron beam have to be matched. Since a velocity of electrons is lower than a speed of light, in traveling wave devices, slow waves are used to match a velocity of electrons. Slowing of waves is achieved by using devices called slow-wave system. 
Broadband planar slow-wave systems are widely used in delay lines and traveling wave tubes. Delay lines in turn can be used for signal synchronization in high speed Digital circuits. Slow-wave system is an essential part of a traveling-wave tube. Because of its high power and efficiency, traveling wave tubes find many applications in terrestrial and satellite communications systems, electronic warfare.

In microwave devices, helical and meander slow-wave systems are most commonly used. Meander slow-wave systems are of a special interest, because they provide compact size and high efficiency in wide frequency range. Meander slow-wave system find applications in antennas, monolithic microwave integrated circuits, filters and couplers.

When investigating complex electrodynamical structures it is very important to choose a right numerical method. In investigation of broadband meander slow-wave systems, finite difference time domain (FDTD) and moment methods (MoM) are often used. FDTD is more flexible, easily programmable, but requires more computer resources than MoM. Because of its flexibility, FDTD is more suitable for solving scattering problems. When analyzing complex structures such as meander slow-wave systems with additional shields, it is purposeful to use a moment method, as investigation shows that moment method is more accurate.

\section{Models of meander slow-wave systems with additional shields}

A meander slow-wave system is shown in Figure S1. It consists of a conductor which has a shape of meander. Conductor is placed on a dielectric substrate with the permittivity $\varepsilon_{\mathrm{r}}$ and a thickness $h$. Bottom of the substrate is covered by a conductive layer which has a function of a grounded external shield. A single conductor has a length of $2 \mathrm{~A}$ and width $w$, a gap between neighboring conductors is $s$.

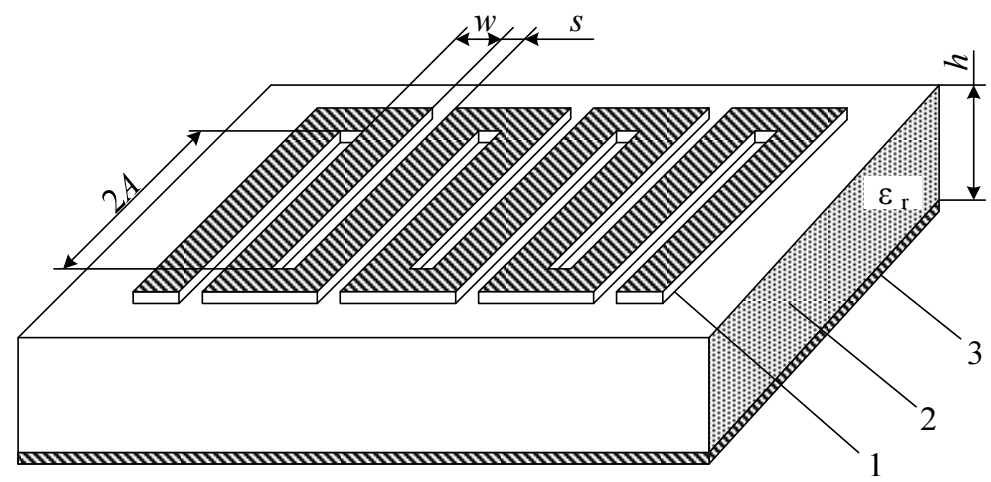

Fig. S1. Meander slow-wave system: 1 - meander-shape conductor; 2 - dielectric substrate of relative permittivity $\varepsilon_{\mathrm{r}} ; 3$ - external shield

In order to reduce the electromagnetic interaction, additional shields are inserted between adjacent meander conductors and connected to an external shield by vias. 
To improve the dispersive properties and increase a bandwidth of meander slowwave system, four models of meander slow-wave systems, whose topologies are shown in Figure S2, are created and investigated. From Figure S2 it can be seen that created models of meander slow-wave systems differ in position of via along the additional shield.

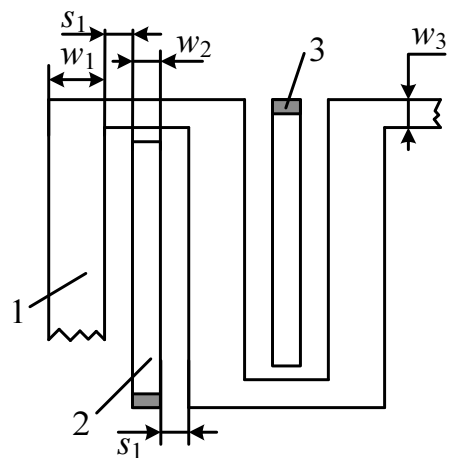

a)

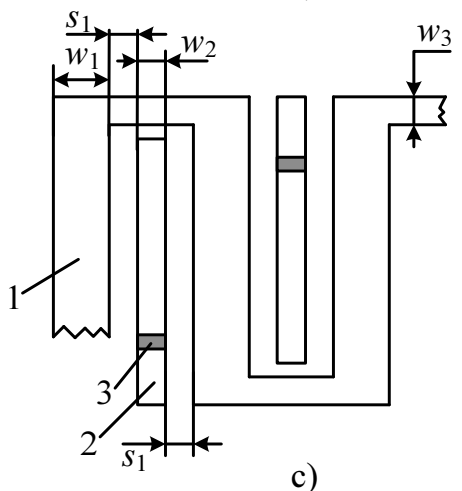

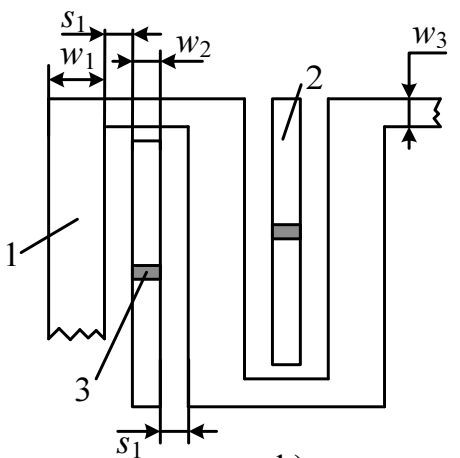

b)

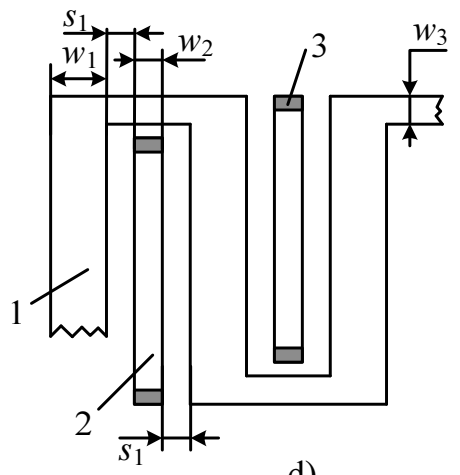

d)

Fig. S2. Topology of meander slow-wave system with additional shields grounded at: a) - one edge; b) - center; c) - point between the edge and center; d) - both edges; 1 - meander-shape conductor; 2 - additional shield; 3 - grounded via

Investigation of meander slow-wave system with additional shields was performed using Sonnet ${ }^{\mathbb{R}}$ software. Slow-wave system has a rectangular shape; it consists of 7 parallel conductors which are connected in a shape of meander and 6 additional shields which are connected by vias at both ends to an external shield. Strips of a meander together with additional shields are placed on a dielectric plate of permittivity $\varepsilon_{\mathrm{r}}$. Bottom of a plate is covered with metal which forms an external shield. Above the dielectric plate is air. Therefore cross-section of a system contains two layers of dielectric. Bottom layer has a permittivity of $\varepsilon_{\mathrm{r}}=7.3$, which is a glass ceramic dielectric material. Top layer consists of air which has a relative dielectric permittivity of 1 . Input and output of a sys- 
tem were placed at the center of meander. Initial dimensions of a meander slow-wave system are: $2 A=19.6 \mathrm{~mm}, w_{1}=0.5 \mathrm{~mm}, w_{2}=0.25 \mathrm{~mm}, w_{3}=0.2 \mathrm{~mm}, h=0.5 \mathrm{~mm}, s_{1}=$ $0.65 \mathrm{~mm}, s_{2}=0.2 \mathrm{~mm}$. During the investigation perfect conductors were used. So investigated system has no loss.

In the process of designing meander slow-wave systems with additional shields it is purposeful to take into account the ongoing processes on the edges of a system because their topology can have a large impact on system's characteristics. For that matter, models which reflect changes in the areas where adjacent meander conductors connect are created. Also models with different topologies in the area where meander strips are open and form a loop are created. To determine an impact of topology of meander edges on dispersion properties of a slow-wave system, three different topologies of meander slowwave system with additional shields grounded at both edges, shown in Figure S3, were investigated.

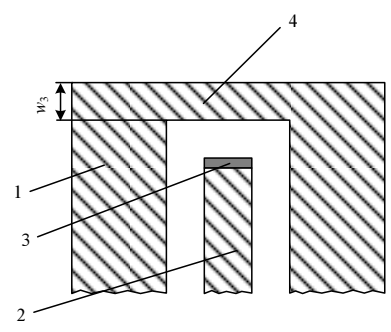

a)

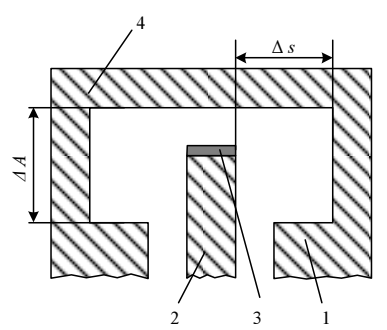

b)

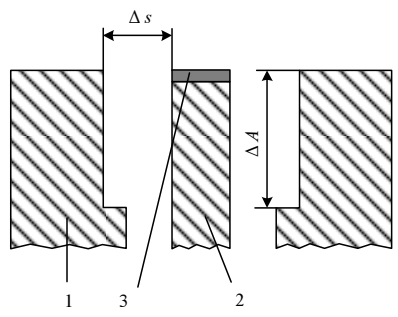

c)

Fig. S3. Investigation of different topologies of meander edges: a) change of a width of a conductor connecting adjacent meander strips; b) gap increase in the area where meander strips form a loop; c) gap increase in the area where meander strips are open

For determination of compatibility of slow-wave system with the signal tract, system's input impedance is often used instead of its characteristic impedance. However there is still a lack of information about input impedance and S-parameters of meander slow-wave systems with additional shields, therefore a technique for determination of input impedance of such systems using Sonnet ${ }^{\circledR}$ is discussed below.

The input impedance of meander slow-wave system with additional shields in the lower frequencies was determined at two points: on the edge of a system and in the center of a system.

Reflections in the path with the slow-wave system do not exist if the internal resistance of the signal source and load resistance are matched with system's input impedance in the lower frequencies. Thus, at a selected low frequency $f$, system's input impedance can be determined by changing the signal source and load resistances until minimum value of $S_{11}$ parameter is obtained. So when load and source resistances are matched with slow-wave system's impedance, least reflections are obtained since $S_{11}$ parameter is known as the input reflection coefficient. In such way input impedance $\underline{Z}_{\mathrm{IN}}(f)$ in the lower frequencies on the edge of the slow-wave system is determined. 
For determination of the input impedance in the lower frequencies in the center of a system, a signal is sent through a port in the center of a system while both ends of a system are loaded by resistances that are equal to slow-wave system's input impedance in the lower frequencies. Since signal is sent simultaneously in both directions the resistance of signal source must be equal to half of the system's input impedance in the lower frequencies. Therefore it must be equal to the half of the load resistance $\underline{Z}_{\mathrm{g}}=\underline{Z}_{\mathrm{a}} / 2$. where $Z_{\mathrm{a}}$ is matched load resistance.

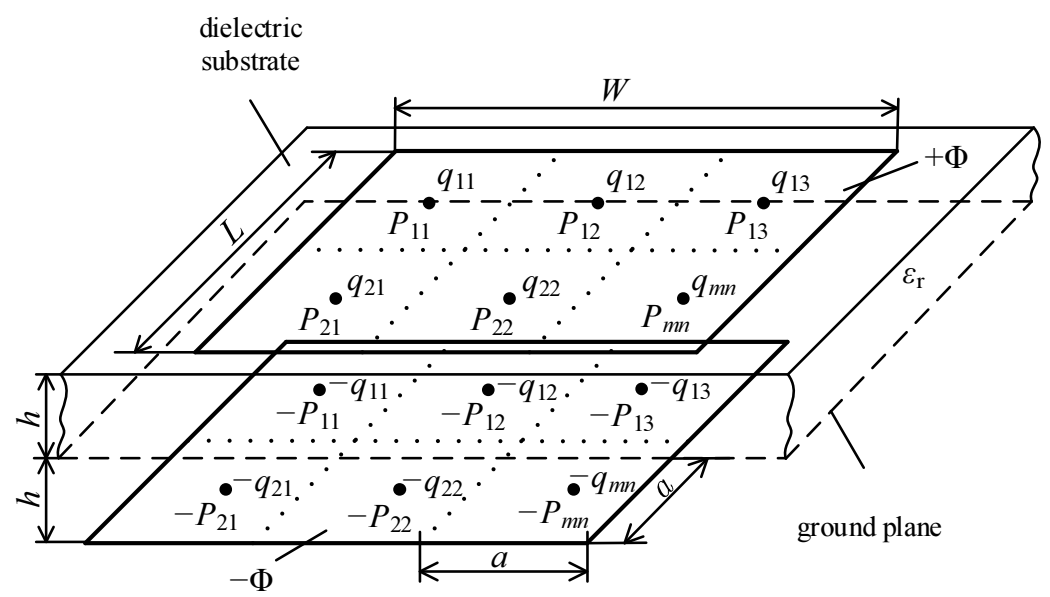

Fig. S4. Rectangular section of meander slow-wave system

In order to reflect the charge distribution in the area of meander slow-wave system where two adjacent strips are connected and point up the electromagnetic interaction between two adjacent strips, techniques for evaluation of 3D distribution of electrical field should be created.

A model of rectangular section of meander slow-wave system is shown in Figure S4. In the model, the section is divided into square sub-areas of size $a \times a$. According to the example of model shown in Figure S4, the number of sub-areas is 6 , so total length of the section is $L=2 a$ and width is $W=3 a$. Ground plane is modeled placing the mirror charges at a distance of $2 h$ from their original charges. It is also can be noted that $h=a$.

Mathematical model of rectangular section of meander slow-wave system, based on the MoM, will consist of system of linear equations which describe dependence of potentials of sub-areas on their charge densities $\rho_{i j}$. Using the MoM and principle of partial images, the influence of every sub-area charge on the potential at the certain point of the section can be obtained by completing three steps:

1. Find self-potential at point $P_{i i}$ that is raised by the charge $q_{i i}$ and its first partial image situated in the same point. It can be shown that potential at the center of uniformly charged square-shaped plate of size $a \times a$ can be calculated as 


$$
\varphi_{0,0}=\frac{a \rho_{S 0}}{\pi \varepsilon} \ln (1+\sqrt{2}),
$$

so

$$
\varphi\left(P_{i i}: P_{i i}\right)=\frac{a(1+K) q_{i i}}{\pi \varepsilon_{0}} \ln (1+\sqrt{2})
$$

where $K$ is the reflection coefficient, which is dependent on relative permittivity of a medium:

$$
K=-\frac{\varepsilon_{\mathrm{r}}-1}{\varepsilon_{\mathrm{r}}+1} .
$$

2. Find potential that is raised by other partial images of charge $q_{i i}$ :

$$
\varphi\left(P_{i i}: P_{i i}\right)=-\frac{a^{2} K\left(1-K^{2}\right) q_{i i}}{4 \pi \varepsilon_{0}} \sum_{n=1}^{\infty} K^{2(n-1)} \frac{1}{2 n h},
$$

where variable $n$ represents $n$-th partial image.

3. Find potential which is raised by the mirror charge $-q_{i i}$ and all its partial images which are situated in the point $-P_{i i}$ :

$$
\varphi\left(P_{i i}:-P_{i i}\right)=-\frac{a^{2}\left(1-K^{2}\right) q_{i i}}{4 \pi \varepsilon_{0}} \sum_{n=1}^{\infty} K^{2(n-1)} \frac{1}{(2 n-1) h} .
$$

To find a potential at point $P_{i j}$ that is raised by the charge $q_{m n}$ situated in the point Pmn, equations of steps 1-3 must be changed. Equation (S2) changes to

$$
\varphi\left(P_{i j}: P_{m n}\right)=\frac{a^{2}(1+K) q_{m n}}{4 \pi \varepsilon_{0}} \frac{1}{l}
$$

where $l=\sqrt{(i-m)^{2}+(j-n)^{2}}$ is the distance between points $P_{i j}$ and $P_{m n}$. Equation (S4) changes to:

$$
\varphi\left(P_{i j}: P_{m n}\right)=-\frac{a^{2} K\left(1-K^{2}\right) q_{m n}}{4 \pi \varepsilon_{0}} \sum_{n=1}^{\infty} K^{2(n-1)} \frac{1}{\sqrt{l^{2}+(2 n h)^{2}}} .
$$

Equation (S5) changes to:

$$
\varphi\left(P_{i j}: P_{m n}\right)=-\frac{a^{2}\left(1-K^{2}\right) q_{m n}}{4 \pi \varepsilon_{0}} \sum_{n=1}^{\infty} K^{2(n-1)} \frac{1}{\sqrt{l^{2}+[(2 n-1) h]^{2}}} .
$$


After the calculations are performed, a matrix equation can be written:

$$
[\mathbf{1}]=[\mathbf{A}] \times[\mathbf{q}] \text {, }
$$

and unknown charges can be obtained solving equation (S9):

$$
[\mathbf{q}]=[\mathbf{A}]^{-1} \times[\mathbf{1}],
$$

where the element $\mathrm{A}_{i j}$ of matrix [A] represents the potential of $i$-th sub area that is raised by the charge in the $j$-th sub-area.

\section{Characteristics of meander slow-wave system with additional shields}

The comparison of phase delay time dependencies on the frequency of proposed models is shown in Figure S5.

From Figure S5 it can be seen that insertion of additional shields increases a phase delay time in lower frequencies and decreases its dispersion. When additional shields are grounded at one edge (Fig. S5, curve 5), bandwidth of a system becomes 1.17 times wider compared to a system without additional shields and equals $1.36 \mathrm{GHz}$. So, in the boundaries of bandwidth, phase delay time dispersion is decreased by 1.74 times. Moreover it can be noticed that when additional shields are inserted and grounded at one edge, in the frequency range of 1.4-1.8 GHz resonance phenomena can be observed and slow-wave system acts like a stop-band filter. After the resonance phenomena, slowwave system can be used in the frequency range up to $2.2 \mathrm{GHz}$.

Frequency response of a phase delay time when additional shields are grounded at the point between the edge and the center is shown in Figure S5, curve 3. It can be seen that when the grounding point of additional shields is shifted by $5 \mathrm{~mm}$ towards the center of a system, phase delay time is increased and its dispersion is decreased. Bandwidth of such system is $\Delta F=1.3 \mathrm{GHz}$. So compared to a system without additional shields, bandwidth is increased by 1.12 times and dispersion of phase delay time in the boundaries of a bandwidth is decreased by 1.55 times. Moreover, when additional shields are grounded at the point between the edge and the center the resonant frequency increases. Therefore the frequency range where resonance phenomena can be observed is also shifted to higher frequencies of $1.85-2.45 \mathrm{GHz}$. In the frequency range from $2.5 \mathrm{GHz}$ deviation of frequency response of phase delay time from linear phase is more than 0.35 radians. Therefore it is not recommended to use this system in higher frequencies.

Figure S5, curve 2 shows the phase delay time dependence on the frequency of meander slow-wave system with an additional shield grounded at the center. It can be seen that when additional shields are grounded in the center, phase delay time in lower frequencies is increased. Compared to a system without additional shields, bandwidth is decreased to $1.09 \mathrm{GHz}$ and dispersion of a phase delay time in that frequency range is increased about 1.1 times. Moreover, a resonance phenomenon is shifted to even higher frequencies starting at $2.8 \mathrm{GHz}$. Generally in the boundaries of a bandwidth, alterations of phase delay time of both systems is similar, however grounding of additional shields in the center increases phase delay time from 0.86 to $0.91 \mathrm{~ns}$, or about $6 \%$. 


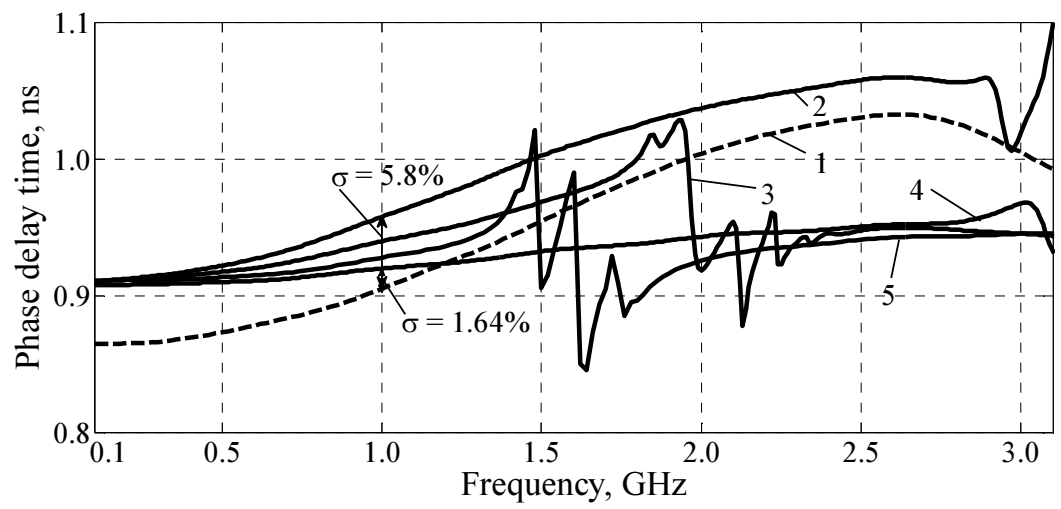

Fig. S5. Comparison of delay time of meander slow-wave systems: 1 - without additional shields; with additional shields grounded at: 2 - center; 3 - point between the edge and the center; 4 - both edges; 5 - one edge

Frequency response of a phase delay time when additional shield are grounded at both edges is shown in Figure S5, curve 4. It can be seen that grounding of additional shields at both edges increases phase delay time in lower frequencies and resonant phenomena starts at $2.8 \mathrm{GHz}$. Calculated bandwidth of such system is $\Delta F=1.97 \mathrm{GHz}$. Phase delay time dispersion in that frequency range is $\Delta t_{\mathrm{v}}=0.035 \mathrm{~ns}$. Phase delay time of a meander slow-wave system without additional shields in the same frequency range is higher and equals $0.135 \mathrm{~ns}$. So insertion of additional shields grounded at both edges decreases phase delay time dispersion by 3.89 times in the frequency range up to $1.97 \mathrm{GHz}$.

In summary meander slow-wave system with additional shields grounded at both edges can be characterized as having best dispersive properties. Such system has a least phase delay time dispersion. Moreover it has a widest bandwidth and can be used in a frequency range up to $1.97 \mathrm{GHz}$.

Values of phase delay time in lower frequencies and bandwidth when width $w_{3}$ of a conductor connecting adjacent meander strips is changed (Fig. S3, a) is shown in Table S1. It can be seen that when width $w_{3}$ is changed, phase delay time of a system is increased. When width of a connecting conductor is reduced by 8 times, phase delay time is increased by $0.8 \%$. However, reduction of $w_{3}$ narrows a bandwidth by $7 \%$ or up to $1.82 \mathrm{GHz}$. An increase of phase delay time remains constant in boundaries of a bandwidth. Meanwhile, when width of a connecting conductor is increased by 3 times, phase delay time is increased by $1.4 \%$, but bandwidth is narrowed even more - by $13 \%$ or up to $1.72 \mathrm{GHz}$. Hence a bigger impact is observed when a width $w_{3}$ of a connecting conductor is increased. This effect can be explained by a formation of a capacitive inequality in a meander shape conductor. 
Table S1. Values of phase delay time in lower frequencies and bandwidth of meander slow-wave system with additional shields grounded at both edges when width $w_{3}$ of a conductor connecting adjacent meander strips is changed

\begin{tabular}{|c|c|c|c|}
\hline $\begin{array}{c}\text { Slow-wave } \\
\text { system }\end{array}$ & $w_{3}, \mathrm{~mm}$ & $t_{\mathrm{v} Z \check{D}}, \mathrm{~ns}$ & $\Delta F, \mathrm{GHz}$ \\
\hline 1 & 0.2 & 0.907 & 1.97 \\
\hline 2 & 0.025 & 0.914 & 1.82 \\
\hline 3 & 0.6 & 0.919 & 1.72 \\
\hline
\end{tabular}

Phase delay time dependence on frequency when a width of a gap is increased in the area where strips of meander form a loop (Fig. S3, b) is shown in Figure S6. It can be seen that when $\Delta s$, and naturally a gap is increased, phase delay time is also increased. When width of a gap is increased by 1.5 times, phase delay time is increased by $0.8 \%$, whereas increase of a gap by 2.5 times raises a phase delay time by $2.7 \%$. Such an increase of a phase delay times can be observed over all examined frequency range. However such change in topology narrows bandwidth: in the first case bandwidth is narrowed by $8.2 \%$ or up to $1.81 \mathrm{GHz}$, in the second case - by $12.2 \%$ or up to $1.73 \mathrm{GHz}$.

Phase delay time which is increased due to the changes in topology can be equalized by reducing the length of a meander conductor $2 A$. Frequency response of a reduced phase delay time is shown in Figure S6, curve 4. In such case, dispersive characteristics are not improved; however a total area of a system can be reduced. For example, when length of a meander conductor $2 A$ is reduced to $19 \mathrm{~mm}$, total area of a system is reduced by $3 \%$. This improvement can be important when applying meander slow-wave systems in integrated circuits.

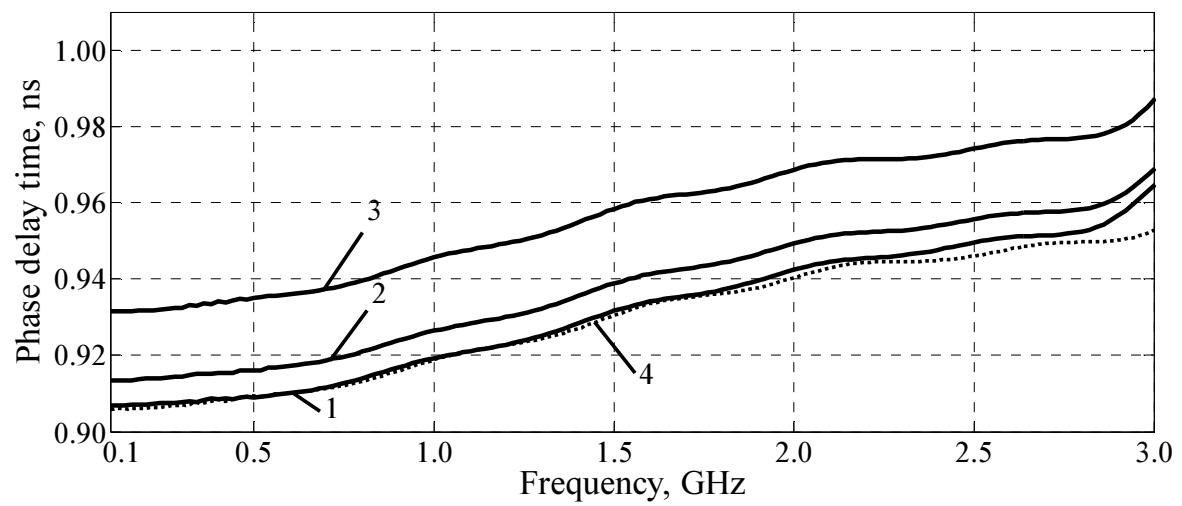

Fig. S6. Phase delay time dependence on frequency when a width of a gap is increased in the area where strips of meander form a loop: 1 - system with initial dimensions; $2-\Delta s=0.3 \mathrm{~mm}, \Delta A=0.6 \mathrm{~mm}, 2 A=19.6 \mathrm{~mm} ; 3-\Delta s=0.5 \mathrm{~mm}$, $\Delta A=0.6 \mathrm{~mm}, 2 A=19.6 \mathrm{~mm} ; 4-\Delta s=0.5 \mathrm{~mm}, \Delta A=0.6 \mathrm{~mm}, 2 A=19 \mathrm{~mm}$ 
Contrariwise to the changes of a gap in the area where strips of meander form a loop, changing a gap in the area where meander strip are open (Fig. S3, c) decreases a phase delay time. However a much less effect on the dispersion properties is observed. For example when a width of a gap is increased by 2.5 times a phase delay time is only reduced by $0.3 \%$.

Results of investigation of frequency characteristics of input impedance of meander slow-wave system with additional shield are presented in Figure S7. Curves 1 and 2 represent a frequency response of the input impedance on the edges of a meander slowwave system with additional shields. Curve 1 represents a resistance $R$ and curve 2 a reactance $X$ of the input impedance.

It can be seen that resistance of the input impedance on the edges of investigated system remains almost constant in a frequency range up to $1.5 \mathrm{GHz}$ and has a value of $48 \Omega$. In the higher frequencies fluctuations of the input impedance can be observed. Fluctuations of input impedance are caused by effect on the edges of a system and electromagnetic interaction between adjacent meander strips. Because of that effects incompatibility between system's input impedance and impedance of generator and load occur. Moreover it should be noted that reactance of the input impedance has a very small value on the whole investigated frequency range so the input impedance on the edges of a meander slow-wave system with additional shields is purely resistive.

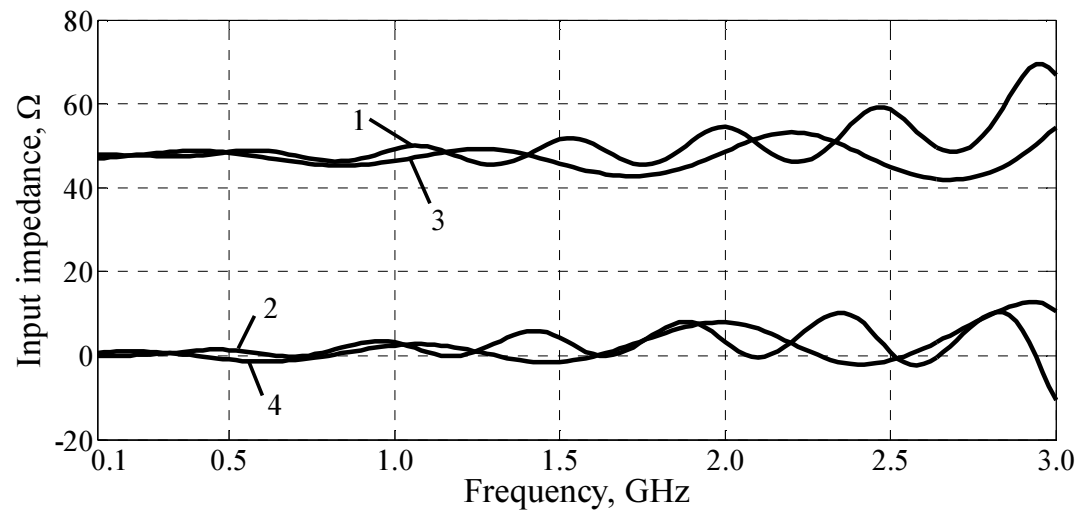

Fig. S7. Frequency response of: 1 - resistance $R$ and 2 - reactance $X$ of the input impedance on the edges of a system; 3 - resistance $R$ and 4 - reactance $X$ of the input impedance in the center of a system

In Figure S7, curves 3 and 4 represent a frequency response of the input impedance in the center of a meander slow-wave system. Curve 3 represents a resistance $R$ and curve 4 a reactance $X$ of the input impedance. Here it can be seen that the input impedance in the center of investigated system remains constant in the wider frequency range up to $2 \mathrm{GHz}$. It can be explained by the fact that in this point of system edge effects has no influence on the input impedance. Input impedance in the center of a system fluctuates due to electromagnetic interaction between adjacent meander strips. Value of the input impedance in the lower frequencies is the same as on the edges of a system. Reac- 
tance of the input impedance in the center of the system as well as on the edges also has very small value so the input impedance in this part of a system is purely resistive too.

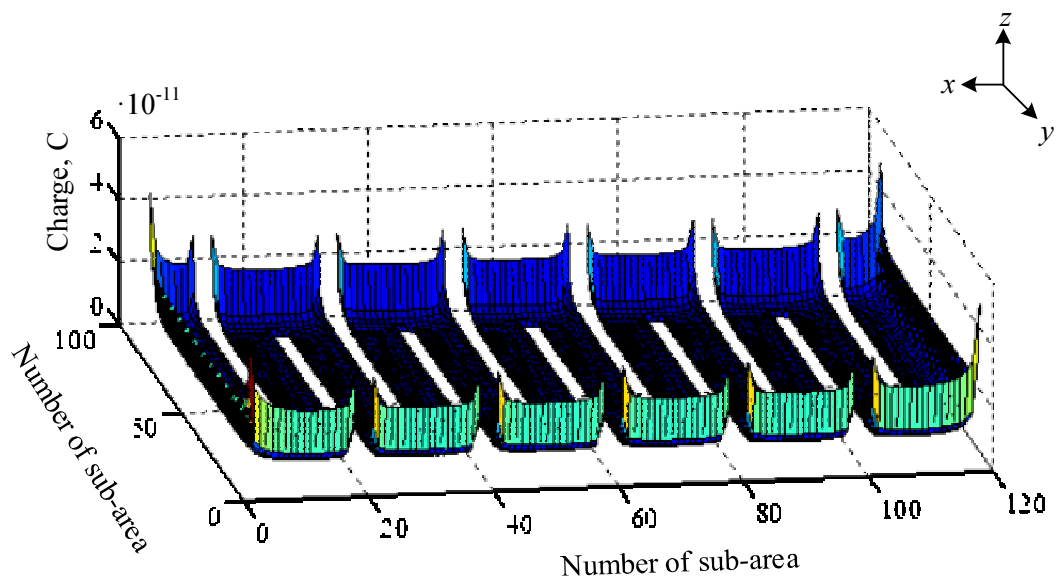

Fig. S8. Surface charge distribution on meander slow-wave system when potential of $+1 \mathrm{~V}$ is applied to the conductor

To analyze the surface charge distribution in complex microstrip structure, a model of meander microstrip delay line was proposed. Analyzed delay line consists of 12 conductors. The design parameters of the delay line are: $A / h=4, w / h=1, s / h=0.25$. Every single meander line strip was divided into 8 sub-areas along $x$-axis and into 80 sub-areas along $y$-axis.

Surface charge distribution, when the potential of $+1 \mathrm{~V}$ is applied to the meander conductor is shown in Figure S8. It is seen that more charge is concentrated on the strips of the conductor. Moreover, sharp increase of a charge on the edges of conductor should be noted. Such an increase shows that proposed technique can be used to evaluate the electrical field on the edges of a structure.

\section{Parametric synthesis of meander slow-wave system with additional shields}

The synthesis of meander slow-wave systems with additional shields is a part of automated design process in which in order to obtain necessary electrical parameters of a device its constructive parameters are changed.

Influence of constructive parameters of a system on its electrical characteristics is unequal. Thus, to achieve the optimal results of the synthesis, influence of main constructive parameters of meander slow-wave system with additional shields on its electrical characteristics must be investigated. Results of investigation will allow to improve the synthesis algorithms of such systems.

Evaluation of constructive parameters of meander slow-wave system with additional shields on its phase delay time, input impedance and bandwidth can be made by 
estimating the influence coefficients. Influence coefficient of particular constructive parameter can be expressed by formula

$$
S=\left(\frac{\Delta p}{p_{0}}\right) /\left(\frac{\Delta d}{d}\right),
$$

where $\Delta p$ - a change in the electrical characteristic of a slow-wave system; $p_{0}-$ value of electrical characteristic of slow-wave system with initial parameters; $\Delta d-$ a change in constructive parameter of a slow-wave system; $d$ - initial value of constructive parameter. During the investigation, when evaluation of influence coefficients was made, constructive parameters were reduced by $1 \%$.

Investigation results of influence coefficients of constructive parameters on phase delay time, input impedance and bandwidth of meander slow-wave system with additional shields grounded at both edges are summarized in Table S2.

In summary, changing of the length of meander conductor has the biggest impact on the phase delay time of meander slow-wave system with additional shields. When length $2 A$ is reduced by $1 \%$, phase delay time is also reduced by $1 \%$. Less impact is observed when changing parameters of dielectric substrate: relative permittivity $\varepsilon_{\mathrm{r}}$ and thickness $h$. Reduction of $\varepsilon_{\mathrm{r}}$ by $1 \%$, decreases a phase delay time by $0.5 \%$, while reduction of thickness of dielectric substrate $h$ increases a phase delay time by $0.1 \%$.

Table S2. Influence of constructive parameters of meander slow-wave system with additional shields grounded at both edges on its electrical parameters

\begin{tabular}{|c|c|c|c|}
\hline \multirow[t]{2}{*}{ Constructive parameter } & \multicolumn{3}{|c|}{$\begin{array}{l}\text { Influence coefficients when } \\
\text { corresponding constructive parameter is } \\
\text { reduced by } 1 \%\end{array}$} \\
\hline & $Z_{\mathrm{IN}}$ & $t_{\mathrm{v}}$ & $\Delta F$ \\
\hline Length of meander conductor $2 A$ & 0 & 1 & -1.36 \\
\hline Width of meander conductor $w_{1}$ & 0.3 & 0.06 & -0.68 \\
\hline Width of additional shield $w_{2}$ & 1 & 0 & 0 \\
\hline $\begin{array}{l}\text { Width of a gap between adjacent meander conduc- } \\
\text { tors } s\end{array}$ & 0.5 & 0.07 & -0.68 \\
\hline Relative permittivity of dielectric substrate $\varepsilon_{\mathrm{r}}$ & -0.5 & 0.5 & -1.36 \\
\hline Thickness of dielectric substrate $h$ & 0.2 & -0.1 & -0.68 \\
\hline
\end{tabular}

In summary, changing the width of additional shields $w_{2}$ has the biggest impact on the system's input impedance. When width $w_{2}$ is reduced by $1 \%$, input impedance is also reduced by $1 \%$. Less impact is observed when changing a gap between adjacent meander strips $s$ and relative permittivity of dielectric substrate $\varepsilon_{\mathrm{r}}$. Reduction of $\varepsilon_{\mathrm{r}}$ by $1 \%$, increases an input impedance by $0.5 \%$, while reduction of gap $s$ decreases an input impedance by $0.5 \%$. Influence coefficients of other constructive parameters, such as 
dielectric substrate thickness $h$ and meander conductor width $w_{1}$, are even smaller and their values are $0.2-0.3$.

From Table S2 it can be seen that biggest impact on the system's bandwidth is observed when changing length of meander conductor $2 A$ and relative permittivity of dielectric substrate $\varepsilon_{\mathrm{r}}$. Reduction of these parameters by $1 \%$, increases a bandwidth $\Delta F$ by $1.36 \%$. Less impact is observed when changing width of meander conductor $w_{1}$, width of a gap between adjacent meander conductors $s$ and thickness of dielectric substrate $h$. Reduction of these parameters by $1 \%$, increases $\Delta F$ by $0.68 \%$.

Table S3. Electrical properties and constructive parameters of synthesized meander slow-wave system with additional shields grounded at both edges

\begin{tabular}{|c|c|c|c|c|c|c|c|c|c|c|}
\hline 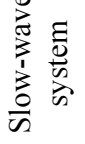 & $\begin{array}{l}\mathscr{n} \\
\xi \\
\xi\end{array}$ & $\begin{array}{l}\mathbf{C} \\
\hat{z} \\
\hat{N}\end{array}$ & 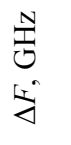 & 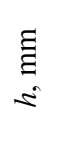 & $\omega$ & $\begin{array}{l}\Xi \Xi \\
\Xi \\
\vec{\Xi}\end{array}$ & 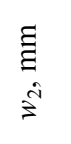 & $\begin{array}{l}\text { E } \\
\text { is }\end{array}$ & $\begin{array}{l}\Xi \\
\Xi \\
\vec{J}\end{array}$ & $z$ \\
\hline LS1 & 1 & 50 & 2.72 & 0.13 & 6.15 & 0.22 & 0.47 & 0.9 & 25 & 5 \\
\hline LS2 & 1 & 75 & 2.72 & 0.25 & 6.15 & 0.18 & 0.8 & 0.9 & 25 & 5 \\
\hline LS3 & 3 & 50 & 1.82 & 0.13 & 6.15 & 0.22 & 0.4 & 0.9 & 25.5 & 15 \\
\hline LS4 & 1 & 50 & 2.67 & 0.3 & 4.4 & 0.62 & 0.85 & 0.42 & 29.4 & 5 \\
\hline
\end{tabular}

Verification results of synthesis algorithm based on influence coefficients are summarized in Table S3. Herein, electrical characteristics and synthesized constructive parameters of meander slow-wave system with additional shields grounded at both edges are presented. Two different dielectric substrates were used during the synthesis: RO3006 ${ }^{\mathrm{TM}}$ by Rogers Corporation, with relative permittivity of $\varepsilon_{\mathrm{r}}=6.15$ and FR4, with relative permittivity of $\varepsilon_{\mathrm{r}}=4.4$.

\section{General conclusions}

1. A technique which allows modeling of 3D distribution of electric field in meander slow-wave system using method of moments is proposed. Investigation of distribution of electric field pointed up the electromagnetic bond between adjacent meander strips which causes phase delay time dispersion. Therefore, in order to improve the dispersion properties of meander slow-wave system, four computer models of meander slow-wave system with additional shields grounded at different point are created and investigated.

2. As shown by computer-based experiment, insertion of additional shield increases a phase delay time in lower frequencies and thus reduces its dispersion. Meander slow-wave system with additional shields grounded at both edges has least phase delay time dispersion. With the insertion of additional shield grounded at both edges, phase 
delay time dispersion in the frequency range up to $1.97 \mathrm{GHz}$ is reduced by 3.89 times and is less than $\Delta t_{\mathrm{v}}=0.035 \mathrm{~ns}$.

3. In the process of designing meander slow-wave systems with additional shields it is purposeful to take into account the ongoing processes on the edges of a system because their topology can have a large impact on system's characteristics. For that matter, models which reflect changes in the areas where adjacent meander conductors connect are created. Also models with different topologies in the area where meander strips are open and form a loop are created.

4. Investigation of meander slow-wave system with additional shield and modified topologies of edges pointed out that change in a width of a conductor connecting adjacent meander strips increases a phase delay time of a system. This effect can be explained by a formation of a capacitive inequality in a meander shape conductor. Moreover, reduction of total area of a system, while its dispersive properties remain unchanged, can be achieved by increasing a gap in the area where meander strips form a loop. For a meander conductor length of $19 \mathrm{~mm}$, gap width of $0.5 \mathrm{~mm}$ and gap length of $0.6 \mathrm{~mm}$, area of a system is reduced by $3 \%$.

5. A proposed technique for determination of input impedance of meander slow-wave system with additional shields, with the help of computer-based experiment allowed to demonstrate that input impedance on the edges of a system remains constant in the frequency range up to $1.5 \mathrm{GHz}$, and in the center of the system - up to $2 \mathrm{GHz}$, while its value in the lower frequencies in the center and on the edges is the same.

6. Estimation of influence coefficients of constructive parameters of meander slow-wave system with additional shields and evaluation of sensitivity of phase delay time, input impedance and bandwidth to a changes of constructive parameters, enabled a creation of algorithm for parametric synthesis of meander slow-wave system with additional shields grounded at both edges which was verified by synthesizing four slow-wave systems. 



\section{Priedai $^{1}$}

A priedas. Bendraautorių sutikimai teikti publikacijų medžiagą disertacijoje. B priedas. Autoriaus mokslinių publikacijų disertacijos tema kopijos.

${ }^{1}$ Priedai pateikiami pridètoje kompaktinèje plokštelèje 


\section{Edvardas METLEVSKIS}

PLAČIAJUOSČIŲ PLANARIŲJỤ LĖTINIMO SISTEMỤ MODELIAI IR JŲ TYRIMAS

Daktaro disertacija

Technologijos mokslai,

elektros ir elektronikos inžinerija (01T)

MODELS OF BROADBAND PLANAR SLOW-WAVE SYSTEMS AND THEIR INVESTIGATION

\section{Doctoral Dissertation}

Technological Sciences,

Electrical and Electronic Engineering (01T)

201405 12. 11,5 sp. I. Tiražas 20 egz.

Vilniaus Gedimino technikos universiteto

leidykla „Technika“,

Saulètekio al. 11, 10223 Vilnius,

http://leidykla.vgtu.It

Spausdino UAB "Ciklonas"

J. Jasinskio g. 15, 01111 Vilnius 